\title{
ZUSES
}

\section{Preliminary Geologic Map of the Greater Antilles and the Virgin Islands}

By Frederic H. Wilson, Greta Orris, and Floyd Gray

Pamphlet to accompany

Open-File Report 2019-1036 


\title{
U.S. Department of the Interior \\ DAVID BERNHARDT, Secretary
}

\author{
U.S. Geological Survey \\ James F. Reilly II, Director
}

U.S. Geological Survey, Reston, Virginia: 2019

For more information on the USGS - the Federal source for science about the Earth, its natural and living resources, natural hazards, and the environment-visit https://www.usgs.gov or call 1-888-ASK-USGS.

For an overview of USGS information products, including maps, imagery, and publications, visit https://store.usgs.gov.

Any use of trade, firm, or product names is for descriptive purposes only and does not imply endorsement by the U.S. Government.

Although this information product, for the most part, is in the public domain, it also may contain copyrighted materials as noted in the text. Permission to reproduce copyrighted items must be secured from the copyright owner.

Suggested citation:

Wilson, F.H., Orris, G., and Gray, F., 2019, Preliminary geologic map of the Greater Antilles and the Virgin Islands: U.S. Geological Survey Open-File Report 2019-1036, pamphlet 50 p., 2 sheets, scales 1:2,500,000 and 1:300,000, https://doi.org/10.3133/ofr20191036.

ISSN 2331-1258 (online) 


\section{Contents}

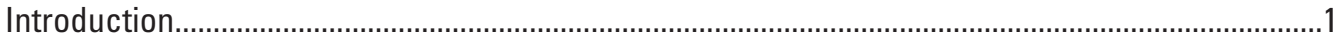

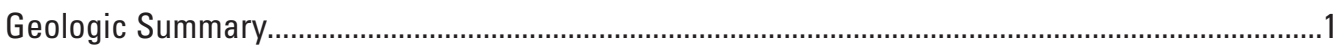

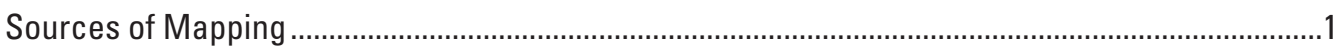

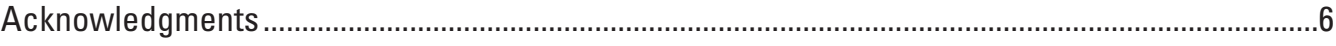

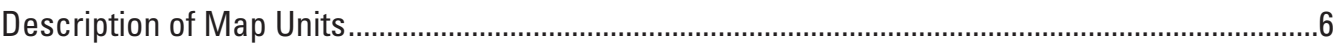

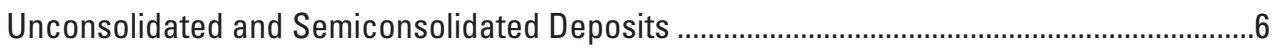

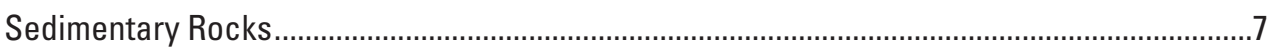

Tertiary Sedimentary Rocks .....................................................................................

Tertiary to Cretaceous Sedimentary Rocks..................................................................17

Cretaceous Sedimentary Rocks ................................................................................

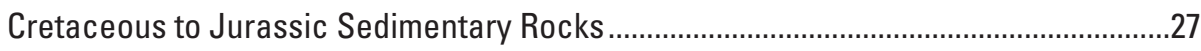

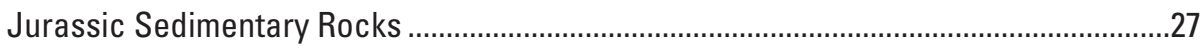

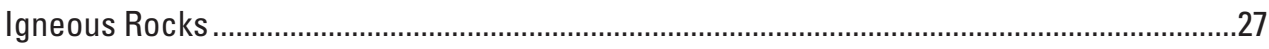

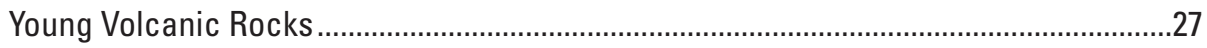

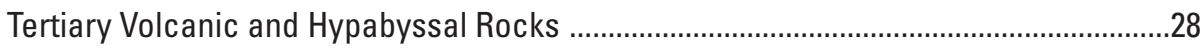

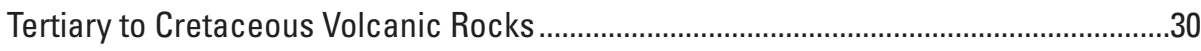

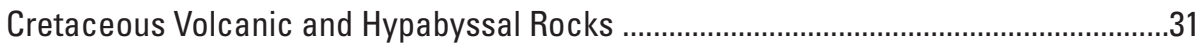

Cretaceous to Jurassic Volcanic and Hypabyssal Rocks ................................................35

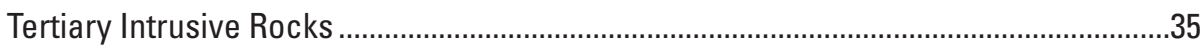

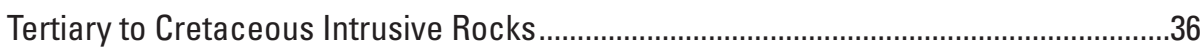

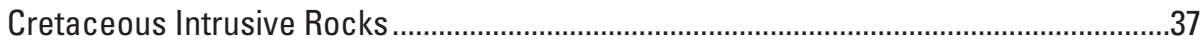

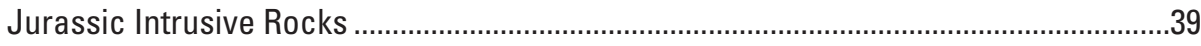

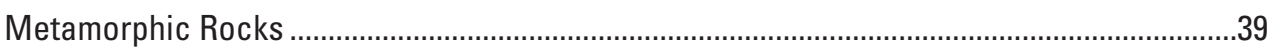

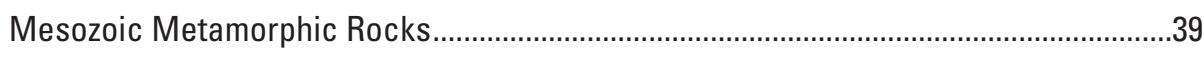

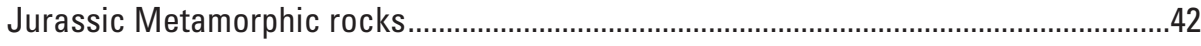

Ophiolite and Ophiolite-Associated Rocks ...................................................................43

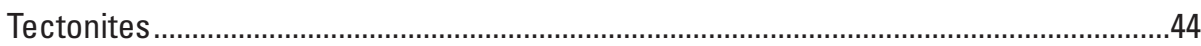

Tectonically and Hydrothermally Altered Rocks ...........................................................4

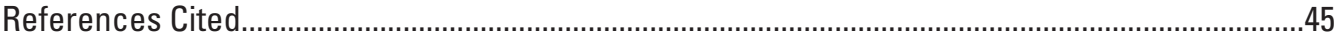

\section{Tables}

1. Map units in the Greater Antilles and the Virgin Islands, showing unit age or position and general geographic distribution

2. Radiometric ages from the Greater Antilles and the Virgin Islands, including $\mathrm{K} / \mathrm{Ar},{ }^{40} \mathrm{Ar} /{ }^{39} \mathrm{Ar}$, fission-track, $\mathrm{Rb} / \mathrm{Sr}, \mathrm{U} / \mathrm{Pb}, \mathrm{Re} / \mathrm{Os}$, and $\mathrm{Lu} / \mathrm{Hf}$ age determinations [table title is included here for continuity; complete table is available online at https://doi.org/10.3133/ofr20191036]

3. Formations in the Devil's Race Course Group, Jamaica .................................................34

\section{Map Sheets}

1. Preliminary Geologic Map of the Greater Antilles and the Virgin Islands

Compiled by Frederic H. Wilson, Greta Orris, and Floyd Gray

2. Preliminary Geologic Map of Puerto Rico and the Virgin Islands

Compiled by Frederic H. Wilson, Greta Orris, and Floyd Gray 


\title{
Preliminary Geologic Map of the Greater Antilles and the Virgin Islands
}

\author{
By Frederic H. Wilson, Greta Orris, and Floyd Gray
}

\section{Introduction}

This geologic map of the Greater Antilles and the Virgin Islands is a compilation of information from the literature, integrated to provide a seamless geologic map of the region. The geology shown on sheet 1 covers Cuba, the island of Hispaniola, which includes Haiti and the Dominican Republic, Jamaica, the Cayman Islands, Puerto Rico, and the U.S. and British Virgin Islands. A second more detailed sheet shows the geology of Puerto Rico and the Virgin Islands. Accompanying the maps are two tables: table 1 lists the map units (in alphabetical order by map-unit label), their ages, and the countries or territories in which they can be found; table 2 lists a compilation of radiometric age determinations for the region.

\section{Geologic Summary}

The Greater Antilles and the Virgin Islands, although they appear to reflect the character of a magmatic arc, actually represent multiple, distinct geologic features. Only in Cuba are there unquestioned Jurassic-age, and perhaps older, rocks present. On the islands of Hispaniola (Haiti and the Dominican Republic) and Puerto Rico, metamorphic assemblages contain rocks that may be of Jurassic age. Ophiolite assemblages that may include rocks of Jurassic age are present in Cuba, the Dominican Republic, Haiti, and Puerto Rico. Metamorphic rocks of Cretaceous age are more widespread, present in Cuba, Hispaniola, and the U.S. and British Virgin Islands. Cretaceous plutonic rocks are present in Cuba and Puerto Rico, as well as in the Dominican Republic (in the Cordillera Central and in the eastern part of the country). Gabbro and trondhjemite of inferred Early Cretaceous age are present in the U.S. Virgin Islands. Cretaceous volcanic rocks are widespread in Cuba, Hispaniola, Puerto Rico, and the Virgin Islands; they are of variable age and do not appear to reflect a single arc system. Cretaceous volcanic rocks are also found in Jamaica, in inliers on the eastern part of the island. Eocene volcanic rocks are prominent in southern Cuba, Haiti, eastern Jamaica, Puerto Rico, and the Virgin Islands. Volcanic rocks possibly as young as early Miocene are present in the southern Dominican Republic; the youngest volcanic rocks in the region are the Low Layton Lavas of Jamaica of late Miocene age and alkali basalt of Quaternary age on Hispaniola.

Carbonate rocks are an important component of the sedimentary section in the Greater Antilles, which is as old as Jurassic in Cuba and as young as Holocene in many areas. In Cuba, Early Cretaceous sedimentary rocks tend to be dominantly carbonates; volcanic clasts and debris are not present until the Late Cretaceous in Cuba, as well as in Jamaica and Puerto Rico. In contrast, Early Cretaceous volcaniclastic sedimentary rocks are common in the Virgin Islands. Olistostrome deposits are commonly described in latest Cretaceous and Eocene rocks; in the Paleocene and the early Eocene, these deposits are commonly associated with mélange units. Volcanic debris and tuff are common in sedimentary rocks of Paleocene and Eocene age, typically associated with carbonate rocks. Sedimentary rocks that postdate the Eocene either are dominantly carbonates or are mixed clastic and carbonate rocks in which the clastic component reflects erosion of earlier units, including older carbonate rocks. Rocks that contain lignite, which are only present in Cuba and on Hispaniola, generally are of Miocene age. The map units shown here are integrated across the islands of the Greater Antilles and the Virgin Islands; table 1 provides a list of map units, alphabetical by unit label, that indicates the countries or territories within which a unit appears.

\section{Sources of Mapping}

The primary source of mapping for Cuba was the compilation of Pushcharovsky and others (1988), supplemented by Pardo (2009). The stratigraphic nomenclature used in these two sources was somewhat at variance; Pardo (2009) was generally used for the definitions of map units, whereas Pushcharovsky and others (1988) provided the spatial data. Iturralde-Vinent and others (2016) provided an overview of the geology of Cuba.

Vila and others (1985) was the primary source of mapping for Haiti, and Toloczyki and others (1991) provided data for the Dominican Republic. However, neither of these sources used stratigraphic nomenclature in any systematic way; Vila and others (1985) tended to lump similar units throughout the country, whereas Toloczyki and others (1991) generally described units 
Table 1. Map units in the Greater Antilles and the Virgin Islands (listed alphabetically by map-unit label), showing unit age or position (in parentheses) and general geographic distribution.

\begin{tabular}{|c|c|c|}
\hline $\begin{array}{l}\text { Map-unit } \\
\text { label }\end{array}$ & Map unit (age or position) & Country or territory \\
\hline bu & Bedrock of unknown type (age unknown) & Puerto Rico \\
\hline Jgr & Rio Cana Granite (Middle Jurassic) & Cuba \\
\hline Jlc & Limestone and dolostone (Upper Jurassic) & Cuba \\
\hline $\mathrm{Jm}$ & Metasedimentary rocks including marble (Jurassic) & Dominican Republic \\
\hline Jmg & Mafic schist and amphibolite (Late to Middle Jurassic) & Cuba; Dominican Republic \\
\hline Jsch & Metamorphic complexes characterized by glaucophane schist (Jurassic?) & Cuba; Dominican Republic \\
\hline Jvs & San Cayetano Formation (Jurassic, Oxfordian to Early Jurassic) & Cuba \\
\hline Kcgl & Volcaniclastic conglomerate (Cretaceous, Maastrichtian to Albian) & Cuba; Jamaica; Puerto Rico \\
\hline Kch & Chert (Cretaceous, Cenomanian to Aptian or lower) & Cuba; Jamaica; U.S. Virgin Islands \\
\hline Kcls & Clastic rocks and reef limestone (Upper Cretaceous, Maastrichtian to Campanian) & $\begin{array}{l}\text { Cuba; Dominican Republic; Puerto } \\
\text { Rico }\end{array}$ \\
\hline $\mathrm{Kcr}$ & Limestone and chert (Cretaceous) & Cuba; Dominican Republic; Haiti \\
\hline Kdh & Diorite and hornblendite (Late Cretaceous, Maastrichtian and Campanian) & Cuba; Puerto Rico \\
\hline Kec & $\begin{array}{l}\text { Carbonate rocks, including biomicritic limestone (Lower Cretaceous, Barremian to Ber- } \\
\text { riasian) }\end{array}$ & Cuba; Jamaica \\
\hline Kelc & Limestone and minor calcarenite (Cretaceous, Turonian to Hauterivian) & Cuba \\
\hline Kevi & Intermediate-composition volcanic rocks (Early Cretaceous, Albian to Barremian?) & $\begin{array}{l}\text { Dominican Republic; Jamaica; } \\
\text { Puerto Rico }\end{array}$ \\
\hline Kevm & Basalt and basaltic andesite (Early Cretaceous, Albian and older) & $\begin{array}{l}\text { Dominican Republic; Puerto Rico; } \\
\text { U.S. Virgin Islands }\end{array}$ \\
\hline Kfv & Intermediate and felsic volcanic rocks (Cretaceous, Campanian to Coniacian) & Cuba \\
\hline Kgb & Gabbro (Cretaceous) & Cuba; U.S. Virgin Islands \\
\hline Kgd & Granodiorite (Late Cretaceous, Maastrichtian and Campanian) & Puerto Rico \\
\hline Kgs & Marble and greenschist (Cretaceous, Cenomanian or older) & $\begin{array}{l}\text { British Virgin Islands; U.S. Virgin } \\
\text { Islands }\end{array}$ \\
\hline Kgu & Granitic rocks, undivided (Late Cretaceous) & Cuba; Puerto Rico \\
\hline Khk & Hypabyssal rocks and keratophyre porphyry (Cretaceous) & Cuba; U.S. Virgin Islands \\
\hline Kip & Intermediate and silicic pyroclastic rocks (Late Cretaceous, Turonian to Cenomanian?) & $\begin{array}{l}\text { British Virgin Islands; Cuba; Puerto } \\
\text { Rico; U.S. Virgin Islands }\end{array}$ \\
\hline KJb & Zurrapandilla Formation and Cajul Basalt (Early Cretaceous to Late Jurassic) & Puerto Rico \\
\hline KJcm & $\begin{array}{l}\text { Mariquita Chert (Cretaceous, middle Turonian? to Jurassic, early Tithonian to late Kim- } \\
\text { meridgian) }\end{array}$ & Puerto Rico \\
\hline KJmc & Mabujina Complex and equivalent rocks (Early Cretaceous or Late Jurassic) & Cuba; Puerto Rico \\
\hline KJmq & Cobrito Formation (Early Cretaceous to Late Jurassic) & Cuba \\
\hline KJmu & Dike complexes (Early Cretaceous or Late Jurassic) & Cuba \\
\hline KJs & Limestone and shale (Lower Cretaceous to Upper Jurassic) & Cuba \\
\hline KJyb & Metasedimentary and metaigneous rocks (Early Cretaceous or Late Jurassic, Tithonian) & Cuba; Jamaica \\
\hline Kkp & Keratophyre (Early Cretaceous) & $\begin{array}{l}\text { British Virgin Islands; U.S. Virgin } \\
\text { Islands; Puerto Rico }\end{array}$ \\
\hline $\mathrm{Klc}$ & Limestone and limestone conglomerate (Upper Cretaceous, Maastrichtian and Campanian) & $\begin{array}{l}\text { Cuba; Dominican Republic; Jamaica; } \\
\text { Puerto Rico; U.S. Virgin Islands }\end{array}$ \\
\hline Klcv & Mixed clastic, carbonate, and volcanic rocks (Upper Cretaceous, Campanian to Coniacian) & Cuba; Jamaica \\
\hline $\mathrm{Klg}$ & Granite (Late Cretaceous, Maastrichtian and Campanian) & Cuba \\
\hline KImv & $\begin{array}{l}\text { Basalt, pillowed and nonpillowed flows, breccia, and tuff (Late Cretaceous, Maastrichtian } \\
\text { to Santonian) }\end{array}$ & $\begin{array}{l}\text { Dominican Republic; Haiti; Jamaica; } \\
\text { Puerto Rico }\end{array}$ \\
\hline Klqm & Quartz monzonite and similar rocks (Late Cretaceous, Maastrichtian and Campanian) & Cuba; Puerto Rico \\
\hline
\end{tabular}


Table 1. Map units in the Greater Antilles and the Virgin Islands (listed alphabetically by map-unit label), showing unit age or position (in parentheses) and general geographic distribution.-Continued

\begin{tabular}{|c|c|c|}
\hline $\begin{array}{l}\text { Map-unit } \\
\text { label }\end{array}$ & Map unit (age or position) & Country or territory \\
\hline Klsv & Sedimentary and volcanic rocks (Upper Cretaceous) & $\begin{array}{l}\text { Cuba; Dominican Republic; Jamaica; } \\
\text { Puerto Rico }\end{array}$ \\
\hline Kmgb & Gabbroic amphibolite and amphibolite (Cretaceous?) & Dominican Republic \\
\hline Kmgd & Granodiorite and tonalite (Cretaceous, Santonian to Albian) & $\begin{array}{l}\text { Cuba; Dominican Republic; Puerto } \\
\text { Rico }\end{array}$ \\
\hline Kmk & Mélange (Cretaceous?) & Dominican Republic \\
\hline $\mathrm{Kmm}$ & Martin Mesa Formation and similar formations (Cretaceous, Turonian and lower) & Cuba \\
\hline $\mathrm{Kmq}$ & Trondhjemite and keratophyre (Early Cretaceous) & U.S. Virgin Islands \\
\hline Kmv & Metavolcanic and meta-volcaniclastic rocks (Early Cretaceous) & $\begin{array}{l}\text { Cuba; Dominican Republic; Haiti; } \\
\text { Cuba }\end{array}$ \\
\hline Kmvm & Mafic volcanic rocks (Cretaceous, Cenomanian to Barremian) & Cuba; U.S. Virgin Islands \\
\hline Kpf & Polier Formation (Lower Cretaceous, Albian to Valanginian) & Cuba \\
\hline Kqd & Quartz diorite (Late Cretaceous, Maastrichtian and Campanian) & $\begin{array}{l}\text { Cuba; Dominican Republic; Puerto } \\
\text { Rico }\end{array}$ \\
\hline Kso & Siltstone and local olistostrome deposits (Upper Cretaceous, Maastrichtian to Campanian) & Cuba; Haiti \\
\hline Kspf & Spilitic basalt (Early Cretaceous) & Puerto Rico; U.S. Virgin Islands \\
\hline Ksr & Rio Nuevo Formation and similar clastic-rock units (Cretaceous, Cenomanian to Albian) & Jamaica; Puerto Rico \\
\hline Ksv & Older mixed clastic, carbonate, and volcanic rocks (Cretaceous, Cenomanian to Albian) & Cuba; Puerto Rico \\
\hline Ksvr & Mixed sedimentary and volcanic rocks (Cretaceous) & Dominican Republic; Haiti \\
\hline Ktg & Metaigneous rocks (Early Cretaceous, Hauterivian to Berriasian) & Cuba \\
\hline Ktu & Tutu Formation (Cretaceous, Santonian to Albian) & $\begin{array}{l}\text { British Virgin Islands; U.S. Virgin } \\
\text { Islands }\end{array}$ \\
\hline $\mathrm{Ku}$ & Undifferentiated clastic rocks (Upper Cretaceous, Maastrichtian to Campanian) & $\begin{array}{l}\text { Cuba; Dominican Republic; Jamaica; } \\
\text { Puerto Rico }\end{array}$ \\
\hline Kue & Older undifferentiated clastic rocks (Upper Cretaceous, Santonian to Cenomanian) & Cuba; Jamaica; Puerto Rico \\
\hline Kvf & Felsic volcanic and hypabyssal rocks (Late Cretaceous, Campanian) & Cuba; Dominican Republic \\
\hline Kvib & Iberia Formation of Cuba (Cretaceous, Turonian to Albian) & Cuba \\
\hline $\mathrm{Kvl}$ & Andesitic breccia, flows, and tuff (Late Cretaceous, Maastrichtian to Santonian) & Cuba; Jamaica; Puerto Rico \\
\hline Kvr & Volcanic rocks, undivided (Cretaceous) & $\begin{array}{l}\text { Cuba; Dominican Republic; Haiti; } \\
\text { Jamaica; Puerto Rico }\end{array}$ \\
\hline Kvss & Volcaniclastic sandstone and mudstone (Upper Cretaceous, Maastrichtian to Campanian) & $\begin{array}{l}\text { Cuba; Puerto Rico; U.S. Virgin } \\
\text { Islands }\end{array}$ \\
\hline Kwi & Water Island Formation, volcanic-clast wacke (Lower Cretaceous) & $\begin{array}{l}\text { British Virgin Islands; U.S. Virgin } \\
\text { Islands }\end{array}$ \\
\hline Kwt & Intermediate and mafic pyroclastic rocks (Cretaceous, Cenomanian to Aptian) & Cuba; Puerto Rico \\
\hline Mzm & Marble (Mesozoic or older) & Cuba; Dominican Republic \\
\hline Mzmd & Mafic rocks, diorite, and gabbro (Mesozoic or older) & Cuba; Dominican Republic \\
\hline Mzs & Serpentinite (Cretaceous or Jurassic?) & Jamaica; Puerto Rico \\
\hline Mzum & Ultramafic and associated rocks (Mesozoic or older) & Dominican Republic; Haiti \\
\hline Qpm & Artificial-fill deposits (Quaternary, Holocene) & Puerto Rico \\
\hline Qs & Surficial deposits, undifferentiated (Quaternary) & $\begin{array}{l}\text { British Virgin Islands; Cayman } \\
\text { Islands; Cuba; Haiti; Jamaica; } \\
\text { Puerto Rico; U.S. Virgin Islands }\end{array}$ \\
\hline QTcr & $\begin{array}{l}\text { Deposits associated with carbonate reefs and reef complexes (Quaternary and upper Ter- } \\
\text { tiary, Pliocene) }\end{array}$ & $\begin{array}{l}\text { British Virgin Islands; Cayman Is- } \\
\text { lands; Cuba; Dominican Republic; } \\
\text { Haiti; Jamaica; Puerto Rico }\end{array}$ \\
\hline QTcs & Marine sand and conglomerate (Quaternary and upper Tertiary, Pliocene) & Cuba \\
\hline
\end{tabular}


Table 1. Map units in the Greater Antilles and the Virgin Islands (listed alphabetically by map-unit label), showing unit age or position (in parentheses) and general geographic distribution.-Continued

\begin{tabular}{|c|c|c|}
\hline $\begin{array}{l}\text { Map-unit } \\
\text { label }\end{array}$ & Map unit (age or position) & Country or territory \\
\hline QTV & $\begin{array}{l}\text { Dos Hermanos and Valle Nuevo volcanic fields (Quaternary, Pleistocene and Tertiary, } \\
\text { Pliocene) }\end{array}$ & Dominican Republic \\
\hline Qvm & Alkali basalt (Quaternary) & Dominican Republic; Haiti \\
\hline Tbt & Intermediate to felsic biotite tuff (Tertiary, early Paleocene) & Puerto Rico \\
\hline Tca & Calcarenite, biocalcarenite, limestone, and marl (Tertiary, Pliocene to Miocene) & $\begin{array}{l}\text { Cuba; Dominican Republic; Haiti; } \\
\text { Puerto Rico }\end{array}$ \\
\hline Tcc & Continental clastic rocks (Tertiary, Pliocene to Miocene) & Cuba; Dominican; Republic Haiti \\
\hline Tec & Limestone containing igneous-rock debris (Tertiary, Eocene) & $\begin{array}{l}\text { British Virgin Islands; Cuba; Domini- } \\
\text { can Republic; Puerto Rico }\end{array}$ \\
\hline Tecd & Limestone and igneous-rock debris, deep-water facies (Tertiary, Eocene) & Cuba \\
\hline Tecr & Conglomerate and sandstone (Tertiary, Eocene) & Cuba; Jamaica; Puerto Rico \\
\hline Tecs & Limestone and igneous-rock debris, shallow-water facies (Tertiary, Eocene) & Cuba; Jamaica \\
\hline Ted & Diorite and tonalite (Tertiary, Eocene?) & $\begin{array}{l}\text { Cuba; Puerto Rico; U.S. Virgin } \\
\text { Islands }\end{array}$ \\
\hline Tegr & Granite and granodiorite (Tertiary, Eocene?) & British Virgin Islands; Cuba \\
\hline Tepc & Brecciated carbonate and clastic rocks (Tertiary, middle Eocene to Paleocene) & $\begin{array}{l}\text { Cuba; Dominican Republic; Jamaica; } \\
\text { Puerto Rico }\end{array}$ \\
\hline Tes & Mixed clastic and lesser carbonate rocks (Tertiary, Eocene) & $\begin{array}{l}\text { Cuba; Dominican Republic; Jamaica; } \\
\text { Puerto Rico }\end{array}$ \\
\hline $\operatorname{Tfg}$ & Fault breccia (Tertiary, Eocene) & Puerto Rico \\
\hline Tgn & Gabbronorite, norite, and diorite (Tertiary, Eocene) & $\begin{array}{l}\text { British Virgin Islands; Cuba; Puerto } \\
\text { Rico; U.S. Virgin Islands }\end{array}$ \\
\hline Thb & Hypabyssal dikes and intrusions (Tertiary) & $\begin{array}{l}\text { British Virgin Islands; Cuba; Puerto } \\
\text { Rico; U.S. Virgin Islands }\end{array}$ \\
\hline TKcs & Conglomerate, sandstone, and claystone (Tertiary? to Cretaceous, Campanian, or lower?) & Puerto Rico \\
\hline TKfs & Flysch (lower Tertiary to Upper Cretaceous) & Cuba; Dominican Republic; Haiti \\
\hline TKga & Granite and aplite (Tertiary, Paleocene to Late Cretaceous, Maastrichtian?) & Dominican Republic \\
\hline TKgb & Fountain Gabbro (Tertiary, Paleocene or Late Cretaceous, Campanian?) & Puerto Rico; U.S. Virgin Islands \\
\hline TKgm & $\begin{array}{l}\text { Granodiorite and quartz monzonite (Tertiary, Paleocene to Late Cretaceous, Maastrich- } \\
\text { tian?) }\end{array}$ & $\begin{array}{l}\text { Jamaica; Puerto Rico; U.S. Virgin } \\
\text { Islands }\end{array}$ \\
\hline TKgs & Alkali syenite (Tertiary, Paleocene to Late Cretaceous, Maastrichtian?) & Puerto Rico \\
\hline TKht & Hydrothermally altered rocks (Tertiary, Eocene, or Cretaceous) & Puerto Rico \\
\hline TKI & Limestone, marl, and tuff (Tertiary, Paleocene and Cretaceous, Maastrichtian) & Cuba \\
\hline TKmv & Andesite and basalt flows and tuff (Tertiary? to Cretaceous, Campanian, or lower?) & Puerto Rico \\
\hline TKqt & Quartz diorite and diorite (Tertiary, Paleocene to Late Cretaceous, Maastrichtian?) & $\begin{array}{l}\text { Dominican Republic; Puerto Rico; } \\
\text { U.S. Virgin Islands }\end{array}$ \\
\hline TKrd & Dacite and keratophyre (Tertiary to Late Cretaceous) & Puerto Rico \\
\hline TKrr & Rhyodacite and rhyolite (Tertiary, Paleocene to Late Cretaceous) & Dominican Republic \\
\hline TKtm & $\begin{array}{l}\text { Granitic rocks, granodiorite, and tonalite (Tertiary, Paleocene to Late Cretaceous, Maas- } \\
\text { trichtian?) }\end{array}$ & $\begin{array}{l}\text { Dominican Republic; Haiti; Puerto } \\
\text { Rico }\end{array}$ \\
\hline TKv & $\begin{array}{l}\text { Extrusive rocks, flows, tuff, and breccia (Tertiary, Paleocene to Late Cretaceous, Campan- } \\
\text { ian?) }\end{array}$ & Puerto Rico \\
\hline TKve & Mixed volcanic and clastic rocks (Tertiary? to Cretaceous, Campanian or lower?) & Cuba; Puerto Rico \\
\hline TKyf & Yaguajay Formation (Tertiary, Paleocene to Cretaceous, Maastrichtian) & Cuba \\
\hline TIme & Limestone, marl, and evaporite deposits (Tertiary, Pliocene to Miocene) & $\begin{array}{l}\text { Cuba; Dominican Republic; Jamaica; } \\
\text { Puerto Rico }\end{array}$ \\
\hline
\end{tabular}


Table 1. Map units in the Greater Antilles and the Virgin Islands (listed alphabetically by map-unit label), showing unit age or position (in parentheses) and general geographic distribution.-Continued

\begin{tabular}{|c|c|c|}
\hline $\begin{array}{l}\text { Map-unit } \\
\text { label }\end{array}$ & Map unit (age or position) & Country or territory \\
\hline Tmc & Limestone, marl, and calcarenite (Tertiary, Miocene) & $\begin{array}{l}\text { Cuba; Dominican Republic; Puerto } \\
\text { Rico; U.S. Virgin Islands }\end{array}$ \\
\hline Tmcc & Mixed clastic and carbonate rocks (Tertiary, Miocene) & Cuba; Haiti; Puerto Rico \\
\hline Tml & Limestone (Tertiary, middle Miocene to middle Eocene) & $\begin{array}{l}\text { Cayman Islands; Dominican Repub- } \\
\text { lic; Haiti; Jamaica }\end{array}$ \\
\hline Tmmc & Mixed clastic rocks (Tertiary, Miocene) & Cuba; Dominican Republic \\
\hline Tmo & Mélange and olistostromes (Tertiary, Eocene to Paleocene) & Cuba; Dominican Republic \\
\hline Tmoc & Limestone and marl (Tertiary, lower Miocene to upper Oligocene) & $\begin{array}{l}\text { Cuba; Dominican Republic; Jamaica; } \\
\text { Puerto Rico }\end{array}$ \\
\hline Tmocc & $\begin{array}{l}\text { Clastic rocks associated with carbonate-rock formations (Tertiary, lower Miocene to upper } \\
\text { Oligocene) }\end{array}$ & $\begin{array}{l}\text { Cuba: Dominican Republic; Puerto } \\
\text { Rico }\end{array}$ \\
\hline Tmos & Clastic rocks (Tertiary, Miocene to Oligocene) & Cuba; Haiti; Puerto Rico \\
\hline Tn & Necker Formation (Tertiary, Eocene?) & British Virgin Islands \\
\hline Toc & Carbonate rocks (Tertiary, Oligocene) & $\begin{array}{l}\text { Cuba; Dominican Republic; Jamaica; } \\
\text { Puerto Rico }\end{array}$ \\
\hline Tocc & Mixed carbonate and clastic rocks (Tertiary, Oligocene) & Cuba; Dominican Republic \\
\hline Toct & Older clastic rocks (Tertiary, Oligocene to Eocene) & Cuba; Dominican Republic \\
\hline Tols & Reef limestone and chert (Tertiary, Oligocene to Eocene) & Cuba; Dominican Republic \\
\hline Tosc & Clastic rocks, including conglomerate (Tertiary, Oligocene) & $\begin{array}{l}\text { Cuba; Dominican Republic; Puerto } \\
\text { Rico; U.S. Virgin Islands }\end{array}$ \\
\hline Tpcr & Volcanic clast-bearing rocks (Tertiary, lower Eocene to Paleocene) & Cuba; Jamaica; Puerto Rico \\
\hline Tv & Intermediate and mafic flows and tuff (Tertiary, Miocene to Eocene) & $\begin{array}{l}\text { British Virgin Islands; Cuba; Do- } \\
\text { minican Republic; Haiti; Jamaica; } \\
\text { Puerto Rico }\end{array}$ \\
\hline Tvc & Pyroclastic rocks (Tertiary, Eocene) & $\begin{array}{l}\text { British Virgin Islands; Cuba; Puerto } \\
\text { Rico; U.S. Virgin Islands }\end{array}$ \\
\hline Trcv & Mixed carbonate and clastic rocks and tuff (Tertiary, Eocene) & Cuba \\
\hline Tvep & Tuff and breccia (Tertiary, early Eocene and late Paleocene) & Cuba; Puerto Rico \\
\hline Tvg & Sedimentary rocks and tuff (Tertiary, lower Eocene to Paleocene) & Cuba \\
\hline Tvs & Volcanic and sedimentary rocks (Tertiary, Eocene) & Dominican Republic \\
\hline
\end{tabular}

using lithologic terminology, not stratigraphic names. We have integrated map units across the island of Hispaniola where the available information allowed correlation.

McFarlane and others (1984) was the primary source of mapping for Jamaica, supplemented by multiple sources that provided more detailed stratigraphic descriptions. Mapping by Hastie (2007) and by Mitchell (2000, 2013a,b), Mitchell and Blissett (2001), and Mitchell and others (2011) was particularly helpful.

A detailed geologic map of the Cayman Islands does not exist; the only available source of mapping was Matley (1926).

The geology of the island of Puerto Rico was based on the map compilation by Krushensky and Schellekens (1999), supplemented by mapping for Isla de Mona by Kaye (1959); the geology of Isla de Culebra was from mapping by Banks (1962); and the geology of Isla de Vieques was from mapping by Learned and others (1973).
In the U.S. Virgin Islands, Donnelly (1966) was the source of mapping for Saint John and Saint Croix, and Rankin (2002) was for Saint Thomas. Helsley (1960) was the primary source of mapping for the British Virgin Islands, with the exception of Anegada Island, whose geology was inferred from information in Kaye (1959).

The majority of these sources focus on sedimentary and, to a lesser extent, volcanic rock units. A few sources, however, reported and integrated radiometric ages on igneous rock units, particularly for plutonic rock units. We have compiled radiometric age determinations available from the region, and we have tried to evaluate their quality and applicability to determining the age of rock units (see table 2). In part, this has involved recalculating all potassium-argon (K/Ar) ages to modern decay constants (Steiger and Jager, 1977). Many sources of radiometric age data did not provide information on the decay constants used, and so we had to infer them in different ways, depending 
on the source. For example, we inferred that the Russian sources used the Russian decay constants that were in use at the time of analysis. We inferred that sources using American and European laboratories that dated from 1977 and earlier used the decay constants commonly in use prior to the revision of Steiger and Jager (1977). In addition, we found that some of the later (post1977) sources continued to use older age determinations (that is, ages determined using decay constants that predate Steiger and Jager [1977]), sometimes mixing the older ages with newer ones that used the newer decay constants. The few uranium-lead $(\mathrm{U} / \mathrm{Pb})$ dates shown here are relatively modern, and we assumed that they were determined using modern and consistent constants. For ages determined by other methods, we were not able to determine the decay constants used.

An additional (and more serious) problem with many of the radiometric ages was that their sources frequently did not provide detailed sample descriptions or even rudimentary location information. Typically, the only location information was from a small graphic image that could not be accurately georeferenced. We tried to indicate the map unit to which an age might apply; however, many ages were determined on hydrothermal minerals or dikes that were not separately mapped. We located the samples as best as we could, but in some cases the locations may only be within a few kilometers of the actual sample collection site. A further concern is that some of the age determinations are analytically suspect, owing to exceedingly large analytical errors, as well as to the not-infrequent use of inappropriate materials (for example, using whole-rock samples to date coarse-grained plutonic rocks). Multiple, widely varying age determinations are reported for some plutonic-rock units; these are difficult to evaluate. We don't know if they reflect dates that are suspect or if they reflect mapping that has lumped pluton phases of varying age into a single plutonic-rock unit.

Table 2. Radiometric ages from the Greater Antilles and the Virgin Islands, including $\mathrm{K} / \mathrm{Ar}$, ${ }^{40} \mathrm{Ar} /{ }^{39} \mathrm{Ar}$, fission-track, $\mathrm{Rb} / \mathrm{Sr}$, U/Pb, $\mathrm{Re} / \mathrm{Os}$, and $\mathrm{Lu} / \mathrm{Hf}$ age determinations [table title is included here for continuity; complete table is available online at https://doi.org/10.3133/ofr20191036].

\section{Acknowledgments}

Compilation of this map has benefited from the knowledgeable support by Keith Labay and Nora Shew in assembling the spatial data and keeping the senior author grounded in ArcGIS. Lisa Koeneman helped in the compilation of radiometric age data for the region. Peer reviews of the manuscript were completed by Thomas Frost and Evan Thoms.

\section{DESCRIPTION OF MAP UNITS}

[Map-unit descriptions here merge units from across Greater Antilles and Virgin Islands region. A small number of units are unique to certain parts of region and are described separately. Within each unit description, names of constituent formal units included in that unit are shown in boldface type upon first mention. Sedimentary-rock units are listed in order by stratigraphic position; igneous- and metamorphic-rock units, by age. Locations of individual map units are provided in table 1]

\section{UNCONSOLIDATED AND SEMICONSOLIDATED DEPOSITS}

Qs $\quad$ Surficial deposits, undifferentiated (Quaternary)-Unconsolidated deposits, including material that ranges in size from clay to coarse cobbles and boulders, mixed with organic debris. Unit represents variety of environments and deposit types, which include alluvium; alluvial fans and talus deposits; lacustrine, swamp, and salt-marsh deposits; landslide and slump deposits; beach and estuarine deposits; and eolian deposits. Unit includes the eolian Santa Fe Formation and (where mapped) the Guevara Formation (Pushcharovsky and others, 1988)

QTer Deposits associated with carbonate reefs and reef complexes (Quaternary and upper Tertiary, Pliocene)

- Semiconsolidated and partly consolidated deposits that represent carbonate reef complexes, located primarily in Cuba but also in Dominican Republic, Haiti, Cayman Islands, British Virgin Islands, Puerto Rico, and Jamaica. Locally, deposits are assigned to formal geologic units.

In Cuba, many defined units either include or entirely consist of reef deposits: these include the Jaimanitas Formation of Pleistocene age, exposed along much of the coast of Cuba; the Vedado and Maya Formations of early Pleistocene to late Pliocene age, primarily exposed along the south coast of central Cuba; and the Canimar Formation of Pliocene age, exposed along the north shore of Cuba in the vicinity of Matanzas and Cárdenas (Pushcharovsky and others, 1988).

In Haiti and Jamaica, reef deposits are terraced; they extend to elevations as high as $640 \mathrm{~m}$ in Haiti, indicating rapid uplift. In the British Virgin Islands, the Rogue's Bay Calcarenite is limestone that contains well-sorted fragments of pelecypods, gastropods, and large foraminifera: these fragments which have been reworked and moderately well rounded are cemented with calcite to form limestone that 
has about 10 percent porosity. Very few silicate grains are present, only plagioclase and epidote being observed, and they make up considerably less than one percent of the rock (Helsley, 1960).

The Ironshore Formation of the Cayman Islands consists of white and cream-colored, consolidated coral sand and marl, which contains abundant coral heads, and coralliferous limestone; the many reef-building corals in this formation are in excellent condition (Matley, 1926). Earle (1924) described similar reef deposits on Anegada Island in the British Virgin Islands.

On Isla de Mona and Isla Monito in western Puerto Rico, the Lino Limestone is a thick-bedded, dense, and finely crystalline limestone and dolostone that commonly is indistinguishable from the underlying Isla Mona Limestone (Kaye, 1959; mapped as the limestone, marl, and evaporite deposits unit [TIme] here); however, Lino Limestone is not mapped here because it was distinguished only in cliff faces. On the southern part of Isla de Mona, which essentially is elevated coral reef, Kaye (1959) also defined the Reef Limestone, and he correlated it with the Ironshore Formation of the Cayman Islands

QTCS Marine sand and conglomerate (Quaternary and upper Tertiary, Pliocene)-Also associated with unit QTcr in Cuba are clastic deposits of marine sand and conglomerate. Deposits of semiconsolidated conglomerate, sand, and marl constitute the Pleistocene Villaroja, Jamaica, Siguanea, Cauto, and Camacho Formations, which are widely exposed on eastern and central Cuba in proximity to its coast; the lower Pleistocene to upper Pliocene Guane Formation of westernmost Cuba; the Datil and Bayamo Formations of southeastern Cuba; and the locally undivided Guane and Guevara Formations of western Cuba and Isla de la Juventud (Pushcharovsky and others, 1988)

Qpm Artificial-fill deposits (Quaternary, Holocene) - Variety of rock types reworked for artificial fill. Mapped only in Puerto Rico (Krushensky and Schellekens, 1999), but most likely also present elsewhere

\section{SEDIMENTARY ROCKS}

\section{TERTIARY SEDIMENTARY ROCKS}

TIme Limestone, marl, and evaporite deposits (Tertiary, Pliocene to Miocene) - Older deposits of reef limestone and marl that represent intertidal facies in Jamaica, Dominican Republic, Cuba, and Puerto Rico. Rocks of this unit exposed on the north coast of Jamaica are part of the Coastal Group (which includes the Bowden and Buff Bay Formations) and are made up of limestone, marl, and clay beds (McFarlane and others, 1984).

In Dominican Republic, these deposits are found in two general areas: near Bahia de Samaná (Samaná Bay) and Parque Nacional Los Haitises (Los Haitises National Park) and in the vicinity of Lago de Enriquillo (Enriquillo Lake) and Parque Nacional Sierra de Bahoruco (Sierra de Bahoruco National Park) (Toloczyki and others, 1991).

In Cuba, they consist of the Manzanillo Formation, exposed in the western part of southernmost Cuba, and the Jucaro and La Cruz Formations, found farther east (Pushcharovsky and others, 1988). Associated with unit in the vicinity of Lago de Enriquillo and, in particular, Laguna del Rincon (Rincon Lagoon) are Pliocene-age evaporite-facies rocks, gypsum, and halite; also associated are modern saltmarsh deposits near Bahia de Samaná.

On Puerto Rico, the Ponce Limestone, which locally has beds of brown clay, reaches its estimated maximum thickness of $850 \mathrm{~m}$ on its southwest coast (Krushensky and Schellekens, 1999). On Isla de Vieques (Vieques Island), soft yellow limestone and dolostone described by Learned and others (1973) may correspond to the Ponce Limestone. In western Puerto Rico, the Isla Mona Limestone, a thickbedded, dense, and finely crystalline limestone and dolostone described by Kaye (1959), makes up most of Isla de Mona and Isla Monito (Mona and Monito Islands)

Tca Calcarenite, biocalcarenite, limestone, and marl (Tertiary, Pliocene to Miocene) - This largely clastic unit is similar in age to the limestone, marl, and evaporite deposits unit (TIme) mapped here; however, it is more widely distributed in the region, being present in Cuba, Haiti, Dominican Republic, and Puerto Rico.

In Cuba, it includes the Loma Triana and Puerto Padre Formations, which consist of calcarenite and sandstone; both formations have limited exposure along the north side of Cuba (Pushcharovsky and others, 1988).

In Haiti, unit typically is exposed inland, somewhat distant from the coast, possibly reflecting rapid uplift as indicated by reef deposits of unit QTcr. In northern exposures on Haiti's Plateau Centrale (Central Plateau), unit is alluvium of the Hinche Formation which has been deposited on an erosion platform (Maurrasse, 1982a). Unit has a high proportion of calcareous pebbles and maximum thickness of $100 \mathrm{~m}$. In the eastern part of the southern peninsula, in the valley of the Bras Gauche (Gauche River), unit, which consists of marine conglomerate containing calcareous and volcanic-rock blocks 
and pebbles, as well as sand and marl, is folded and has maximum thickness of $500 \mathrm{~m}$. Elsewhere, near Port-au-Prince, 1,000 m of coarse conglomerate rests on marl of latest Miocene (Messinian) age (Vila and others, 1985).

Toloczyki and others (1991) reported in the Dominican Republic a deltaic unit that consists of conglomerate, sandstone, marl, and calcarenite in the northwestern part of the Valle del Cibao, and a similar marine sandstone, sandy marl, and conglomerate unit in the Cordillera Central, which is adjacent to the continental clastic rocks unit Tcc.

In Puerto Rico, the Camuy Formation along the north coast is biomicrite, rich in foraminifera, and containing clay lenses; ferruginous calcarenite interbedded with chalky breccia; and, in its upper part, chalky sandstone, sandy limestone, and limestone; estimated maximum thickness is $170 \mathrm{~m}$ (Krushensky and Schellekens, 1999)

Tcc Continental clastic rocks (Tertiary, Pliocene to Miocene)_Limited to Hispaniola, unit is mainly exposed in central part of the island (in Haiti and Dominican Republic) and also between Bahia de Samaná and Monte Cristi in Valle del Cibao (Cibao Valley) in Dominican Republic. A limited area of exposure is also on the southern peninsula of Haiti. Continental lignite facies rocks on the west end of the southern peninsula and also the Lascahobas Formation (Vila and others, 1985) of central Haiti (or, the Las Cahobas Formation of Maurrasse, 1982a) consist of conglomerate, sandstone, sandy shale, local coarse unconsolidated sand, and lignite (Maurrasse, 1982a). The Lascahobas Formation is roughly age equivalent with the finer grained Thomonde Formation and largely younger than the Maissade Formation, a partly equivalent unit that consists of shale, marl, and sandstone. All three units contain lignite (though not in great quantities) that apparently is found in lenses throughout (Maurrasse, 1982a). The rocks are highly folded. A similar coarse clastic unit probably is present in Dominican Republic, though Toloczyki and others (1991) did not describe the presence of lignite there

Tmcc Mixed clastic and carbonate rocks (Tertiary, Miocene)-These clastic and carbonate rocks largely reflect undivided carbonate rocks (subunit Tmc) and mixed clastic rocks (subunit Tmmc). In Cuba, the Yayai Formation of claystone, limestone, and marl is exposed north of Santiago de Cuba, in southeastern Cuba; at both its eastern and western limits, unit transitions to the carbonate rocks subunit Tmc; to its north, unit is adjacent to outcrops of limestone and marl of Miocene to Oligocene age (unit Tmoc). Farther north, the Arabos and Manga Larga Formations, exposed in limited areas north and east, respectively, of Colón $\left(22^{\circ} 44^{\prime} \mathrm{N}\right.$., $80^{\circ} 51^{\prime} \mathrm{W}$.), consist of claystone, marl, sandstone, limestone, and siltstone and are associated with Mesozoic rocks, yet near the carbonate rocks of subunit Tmc.

In Haiti, available mapping (Vila and others, 1985) did not distinguish rock units that are equivalent to the carbonate rocks (subunit Tmc) or the mixed clastic rocks (subunit Tmmc), respectively, as used here; where unit Tmoc is adjacent to the border with central Dominican Republic, unit Tmoc appears to merge with either continental clastic rocks (unit Tcc) or limestone (unit Tml) as mapped in Dominican Republic (Toloczyki and others, 1991).

In Haiti, unit is quite variable and includes several distinct sedimentary sequences: exposures in northern Haiti (near Gros Morne) have upper Oligocene conglomerate at base, overlain by hard, detrital, locally echinoderm-fossil-bearing, yellow limestone, alternating with clayey limestone, gray or brown marl, and calcareous and volcaniclastic sandstone; locally, coarse, clastic lower Miocene rocks contain blocks bearing Eocene fossils. Similar facies are observable in Massif des Montagnes Noires (Black Mountains) and the Chaîne des Matheux, along north side of Golfe de la Gonâve (Gulf of Gonâve). In northwestern Haiti near Trois-Rivieres (Three Rivers) and in Nord-Ouest region (Northwest region), Aquitanian to Burdigalian detrital rocks are present. In Chaîne des Matheux and also along Haiti's southern peninsula, upper Oligocene chalky red flint, commonly slumped, and lower Miocene (Aquitanian to Burdigalian) clastic rocks are present (Vila and others, 1985).

Along the southwest coast of Puerto Rico, calcarenite and calcirudite of the Guanajibo Formation has a maximum thickness of only $30 \mathrm{~m}$; locally, formation has interbeds of lithic sandstone and conglomerate, likely derived from the sedimentary and volcanic rocks subunit KIsv (Krushensky and Schellekens, 1999).

Locally, divided into subunits Tmc and Tmmc

Tmc Limestone, marl, and calcarenite - Limestone, marl, and calcarenite of early Miocene age is very widespread throughout the Greater Antilles. Forming a large part of Cuba, it consists of the Cabo Cruz, Arroyo Palmas, Guines, Cojimar, Jayueyes, Vazquez, and Husillo Formations, some of which may be partially dolomitized (Pushcharovsky and others, 1988).

These rocks are also widely distributed in Dominican Republic, being exposed on the southernmost coast, along the north coast, and in the central part of country north of Valle del Cibao. Unit is largely described as marl that has interbedded calcarenite, except at the eastern tip of Peninsula de 
Samaná (Samaná Peninsula) where a small area of cream-colored limestone is described (Toloczyki and others, 1991).

In Puerto Rico, the Aguada Limestone and the Aymamon Limestone constitute much of the northern part of the island; the Aguada Limestone contains calcarenite at its base, overlain by chalky marl and rubbly limestone, whereas the similar-age Aymamon Limestone consists of dense limestone and chalk (Krushensky and Schellekens, 1999)

Tmmc Mixed clastic rocks - Exposed in central Cuba are conglomerate, sandstone, siltstone, and claystone of the Lagunitas Formation and sandstone, sandy marl, and claystone of the Magantilla Formation (Pushcharovsky and others, 1988). The Lagunitas Formation from the Santa Rosa region of central Cuba is likely derived from erosion of Mesozoic igneous and metamorphic rocks and is in close contact with the marl and limestone of the Arroyo Palmas Formation (part of the carbonate rocks subunit Tmc herein). The Magantilla Formation, of the Camagüey region of Cuba, is likely derived from erosion of surrounding Mesozoic clastic and igneous rocks (carbonate rocks of subunit Tmc are not present adjacent to this formation).

In Dominican Republic, small areas of Miocene clastic rocks are present: conglomerate is exposed on Peninsula de Samaná just north of Bahia de Samaná and west of Santo Domingo near Padre Las Casas; marine sandstone, sandy marl, and conglomerate are exposed in the highlands west of Santo Domingo (Toloczyki and others, 1991)

Tmos Clastic rocks (Tertiary, Miocene to Oligocene) - In southeastern Cuba, the Maquey Formation, which is exposed north and east of Guantánamo, consists of sandstone, siltstone, calcareous clay, and marl that has interbeds of silty biodetrital limestone, and it has large Lepidocyclinas spp., as well as gypsum, lignite, and plant remains. Polymictic sandstone and siltstone of the Cabacú Formation, which has sparsely distributed clayey marl lenses at its base, is exposed in a small area near Baracoa on the easternmost part of the north coast (Pushcharovsky and others, 1988).

In Puerto Rico, the Juana Diaz Formation, of middle Miocene to lower Oligocene age, is exposed along the southwest coast. It consists of a basal, very coarse gravel composed of well-rounded boulders, cobbles, and pebbles of volcanic and intrusive rocks, as well as serpentinite locally, all in a poorly sorted, generally coarse grained, very poorly cemented sand matrix. It is overlain by interbedded, thinto medium-bedded, light-bluish-gray calcareous mudstone and sandstone, which is, in turn, overlain by lenticular, thin- to thick-bedded and locally very thick bedded, white to pale-orange, argillaceous chalk and chalky limestone, which locally is massive biosparite limestone. Locally, upper limestone layers are overlain by fine- to coarse-grained, crossbedded, carbonaceous, light-brown sand and gravel composed of angular clasts of limestone in a sand matrix, as well as a few beds of light-gray and pebbly limestone, all in channels cut into limestone. Lepidocyclina undosa and Clypeaster oxybaphon are common throughout in all but the uppermost part of the formation. Because the formation was eroded prior to deposition of the overlying Ponce Limestone (mapped as the limestone, marl, and evaporite deposits unit TIme here), its thickness is highly variable, having a maximum estimated thickness of $850 \mathrm{~m}$ (Krushensky and Schellekens, 1999)

Tml Limestone (Tertiary, middle Miocene to middle Eocene) - Generally white limestone found in Cayman Islands, Jamaica, Haiti, and Dominican Republic, all in the southern part of the Greater Antilles. Best exposed in Jamaica, the Montpelier Formation of the White Limestone Group is well-bedded limestone and chalk that has flint nodules in its lower sections. Rare marl beds are present interbedded with the chalk (McFarlane and others, 1984). The White Limestone Group of Jamaica, which varies widely in age, has both shallow- and deep-water facies of which the Montpelier Formation is a deep-water (700-1,000 m) facies; here exposures mapped by McFarlane and others (1984) do not include the Montpelier belt of Mitchell (2013a) but do include the deep-water facies that Mitchell (2013a) assigned to the North Coast and John Crow Mountain belts. As defined, the Montpelier Formation ranges in age from middle Eocene to early Miocene.

The Bluff Limestone of the Cayman Islands was correlated with the White Limestone Group by Matley (1926) and, on the basis of Matley's (1926) description, may correspond to the Montpelier Formation, The Bluff Limestone consists of hard, compact, locally dolomitic limestone containing what Matley (1926) described as colloidal silica and is devoid of terrigenous material

Tmoc Limestone and marl (Tertiary, lower Miocene to upper Oligocene)-Dominantly limestone; also includes lesser amounts of marl, clay-rich limestone, calcarenite, and minor sandstone and conglomerate. Primarily exposed in southern Dominican Republic, rocks there may contain more marl than do similar rocks in Cuba; where exposed on Cordillera Central of Dominican Republic, calcarenite is interbedded with marl (Toloczyki and others, 1991). 
In Cuba, unit is made up of several formal units, including the Camazan, Colón, Jaruco, Paso Real, Sevilla Arriba, and Yateras Formations. The Jaruco, Paso Real, Sevilla Arriba, and Colón Formations are found in northwestern Cuba, whereas the Camazan and Yateras Formations are found in southeastern Cuba (Pushcharovsky and others, 1988). Northern units locally include volcanic-rock debris, whereas southern units may include gypsum. The gap across central Cuba between exposures of these two groups of formations is more than $400 \mathrm{~km}$.

In Puerto Rico, the undivided Cibao Formation and its various members are dominantly chalky limestone and lesser amounts of marl; in Guajataca and Rio Indio Limestone Members, rocks may include, or grade into, sandstone or fine-grained conglomerate (Krushensky and Schellekens, 1999).

In Jamaica, the upper Oligocene to lower Miocene Newport Formation, which is one of the youngest shallow-water members of the White Limestone Group, is characterized by thick-bedded or massive, white or pale-colored wackestone and carbonate-rich mudstone; generally exposed in southernmost Jamaica (Mitchell, 2013a). The Brown's Town Formation is characterized by white and locally pale-pink packstone, wackestone, and carbonate mudstone that contains common to abundant, large, lenticular foraminifers or abundant coral (Mitchell, 2013a). According to Mitchell (2013a), previous mappers suggested that the Newport Formation was stratigraphically higher than the Brown's Town Formation and that the Brown's Town Formation was laterally equivalent to the Walderston Formation, whereas Mitchell (2013a) said that the Brown's Town Formation of the White Limestone Group is age equivalent to the Newport Formation. McFarlane and others (1984), however, mapped the Brown's Town Formation and the underlying, lower Oligocene Walderston Formation as a composite unit.

On Saint Croix in U.S. Virgin Islands, the Kingshill Marl is buff-to-white, moderately thick bedded, hard and rather brittle limestone that alternates with soft white or cream-colored marl (Whetten, 1966). The Kingshill Marl was subsequently renamed as the Kingshill Limestone (Gerhard and others, 1978); in addition, its age was extended to late Oligocene to late Miocene, dominantly Miocene (Lidz, 1988)

Tmocc Clastic rocks associated with carbonate-rock formations (Tertiary, lower Miocene to upper Oligocene)-In Dominican Republic, sandstone and shale, which are exposed on the northernmost coast, appear to overlie Cretaceous andesite and Mesozoic ultramafic rocks and, in turn, be overlain by Miocene limestone (Toloczyki and others, 1991).

In small exposures in north-central Puerto Rico, two members of the Cibao Formation, the Almirante Sur Sand Lentil Member and the Miranda Sand Member, are largely clastic rocks. The Almirante Sur Sand Lentil Member is quartz-sandstone and pebbly quartz-sandstone that grades into glauconitic calcarenite, whereas the Miranda Sand Member reflects a channel deposit as much as 260 $\mathrm{m}$ thick that consists of sandstone and pebble- to cobble-conglomerate. South and east of these small exposures are much more extensive exposures of the Mucarbones Sand, which consists of quartz sand interbedded with glauconitic, calcareous sand and thin-bedded, calcareous clay; maximum known thickness, $120 \mathrm{~m}$

Tocc Mixed carbonate and clastic rocks (Tertiary, Oligocene)—Present in Cuba and Dominican Republic, unit includes limestone, marl, siltstone and sandstone.

In Cuba, largely restricted to the northwest half of island, unit includes the Las Cuevas Formation, which is spatially associated with the Mabujina Complex (unit KJmc) of central Cuba; the Guanajay Formation, which also includes conglomerate in the extreme northwestern part of Cuba; the Jatibonico and Tamarindo Formations, found east of the Mabujina Complex; and the widely distributed Tinguaro Formation, which lacks limestone and has claystone.

In Dominican Republic, unit is exposed in two general areas: surrounding Santo Domingo, it consists of marl and interbedded conglomerate; approximately $35 \mathrm{~km}$ west of there is a small outcrop area of sandy marl and interbedded calcarenite. Near La Vega in northern Dominican Republic, consists of conglomerate, sandstone, and subordinate limestone reef deposits; also includes calcareous turbidites (Toloczyki and others, 1991).

Locally, divided into subunits Toc and Tosc

Toc Carbonate rocks - Limestone and marl, in Cuba, Dominican Republic, Jamaica, and Puerto Rico. In Cuba, these rocks have been mapped as many formations, largely in the east half of the island, including the Bitiri, Blanco, Chambas, and Jia Formations. Some rocks are locally dolomitized or may include minor calcarenite (Pushcharovsky and others, 1988).

In northern Dominican Republic, limestone of unit is sparsely distributed and is spatially associated with and overlies Cretaceous andesite. In a small area near Santo Domingo, unit is interbedded with the mixed carbonate rocks and clastic rocks unit (Tocc) where limestone is interpreted as a reef deposit (Toloczyki and others, 1991). 
Unit is most extensively exposed in Jamaica where it consists of the Walderston Formation of the White Limestone Group. According to Mitchell (2013a), the Walderston Formation usually is pink, locally gray or cream-colored, and rarely white grainstone and subsidiary packstone. Generally mediumto thick-bedded, but in many outcrops bedding is lacking. White units, when present, are generally thin. The Walderston Formation is fossil rich (Mitchell, 2013a), which helps define the depositional environment.

In Puerto Rico, the Lares Limestone, which is widely exposed on the northern part of island, is composed of calcilutite (calcareous mudstone) interbedded with chalky limestone and calcareous clay and has an estimated maximum thickness of about $270 \mathrm{~m}$ (Krushensky and Schellekens, 1999)

Tosc Clastic rocks, including conglomerate-Ranges from claystone to conglomerate; most commonly associated with limestone units. In Cuba, consists of the Pedernales, Cienfuegos, Vigia, and Cilindro Formations. The Pedernales Formation consists of $150 \mathrm{~m}$ of unconsolidated, mottled, predominantly brownish-green to brownish-blue, polymictic conglomerate that has silty and sandy matrix. The clasts of mafic and ultramafic igneous rocks, tuff, and Cretaceous and Paleogene limestone are as much as $15 \mathrm{~cm}$ in diameter (Pardo, 2009). The Cilindro Formation is considered by some to be a member of the Maquey Formation, mapped as the clastic rocks unit (Tmos) here. All of these Cuban units include conglomerate; the Cilindro Formation has been described as being dominantly conglomerate but including lenses of sandstone that contain lignite beds (Pushcharovsky and others, 1988).

In Dominican Republic, rocks are described as being primarily conglomerate and spatially associated with Cretaceous and older rocks, which may be their source (Toloczyki and others, 1991).

In Puerto Rico, the San Sebastian Formation is shaly clay, sandstone, and conglomerate; as much as $100 \mathrm{~m}$ thick in outcrop but about $328 \mathrm{~m}$ thick in the subsurface (Krushensky and Schellekens, 1999).

On Saint Croix in U.S. Virgin Islands, the Jealousy Formation is montmorillonitic mudstone and a few thin conglomerate and limestone beds. In subsurface, it is more than $400 \mathrm{~m}$ thick; lowest about $90 \mathrm{~m}$ is gray clay in which a few streaks of limestone, not more than about $10 \mathrm{~cm}$ thick, are present; overlying this is less than $2 \mathrm{~m}$ of calcareous conglomerate that contains volcanic-rock clasts, $25 \mathrm{~m}$ more of gray clay, then $5 \mathrm{~m}$ more of calcareous conglomerate, finally overlain by about $300 \mathrm{~m}$ of greenish-gray clay (Cederstrom, 1950, cited in Whetten, 1966). The Jealousy Formation is poorly stratified, consisting of pebbles, cobbles, and boulders of the Judith Fancy Formation (mapped as the volcaniclastic sandstone and mudstone subunit [Kvss] here), as well as minor diorite, thin oyster beds, corals, and other shallowwater fossil fragments, lenses of red and green clay as long as $6 \mathrm{~m}$ and about $2 \mathrm{~m}$ thick, all in calcareous sandy matrix. Wherever contact between the Jealousy Formation and the Judith Fancy Formation is well exposed in unnamed mountains along the north side of the island, it is a fault that dips $60^{\circ}$ to $75^{\circ}$ southwest (Whetten, 1966)

Toct Older clastic rocks (Tertiary, Oligocene to Eocene)-Dominantly coarse clastic conglomerate and polymictic sandstone; also includes minor siltstone and, locally, marl and limestone. In Cuba, consists of the Caunao and the Condado Formations of early Eocene and late Oligocene age (Pushcharovsky and others, 1988) and apparently has more limestone than similar rocks in Dominican Republic. In Dominican Republic, characterized as flysch, dominantly sandstone and lesser interbedded conglomerate and limestone; ranges in age to early Eocene; some limestone is characterized as thin-bedded and pelagic

Tols Reef limestone and chert (Tertiary, Oligocene to Eocene) - Variably bedded limestone containing interbedded and nodular chert is exposed in Sierra de Baoruco, in southern Dominican Republic near the border with Haiti (Toloczyki and others, 1991).

Very similar, white- to cream-colored limestone, which contains chert or flint nodules, is described in Dominican Republic north of Lago de Enriquillo and on the north side of Bahie de Neiba (Neiba Bay) (Toloczyki and others, 1991). Across the border in Haiti, this limestone adjoins an undivided Eocene to Miocene sedimentary unit that has thick, monotonous limestone sequences. Vila and others (1985) reported that the stratigraphy of this Haitian sedimentary unit is difficult to establish because of abundant carbonate rock facies that are similar to those of the Oligocene to Miocene rocks, as well as the monotony of these facies. Rocks of Eocene sedimentary sequences form the major rock component of the mountains in Haiti; middle Eocene rocks consist of massive limestone (Plaisance Limestone); upper Eocene rocks consist of thin-bedded, white or yellow limestone, which has conchoidal fracturing and reef beds in Massif de Terre Neuve. White, crystalline, commonly brecciated, echinoderm-bearing limestone that ranges in age from middle Eocene to middle Miocene is found in Massif de la Selle; its Oligocene components are rich in flint. In Jérémie region, Oligocene rocks correspond to those of the Jeremie Formation of Maurrasse (1982b, cited in Vila and others, 1985), which are of poorly defined extent. In Ennery region, marly limestone has bioclastic turbidite and volcanic-clast interbeds that are isoclinally folded, having displacement towards the southwest. 
In Dominican Republic south of Barahona, shallow-water, locally porous, white limestone is found (Toloczyki and others, 1991); may be partly equivalent to the White Limestone Group in Jamaica

Tvs Volcanic and sedimentary rocks (Tertiary, Eocene) - Limited exposures of these rocks in eastern Dominican Republic; described as volcano-sedimentary rocks by Toloczyki and others (1991). Two general areas of outcrop are found, one west of Cotuí and another northwest of Higüey in eastern Dominican Republic. These are likely volcaniclastic sedimentary rocks derived from underlying Cretaceous andesite (mapped as the intermediate-composition volcanic rocks subunit [Kevi] here)

Tec Limestone containing igneous-rock debris (Tertiary, Eocene)—Limestone found throughout Greater Antilles and Virgin Islands, having exposures in Cuba, Jamaica, Dominican Republic, and British Virgin Islands.

Widely distributed in Cuba; included formations are the Alvarez, Danuji, Florida, Loma Candela, Nuevitas, Paso Abierto, Perla, Puerto Boniato, Sagua, Todas, Venero, and Vertientes Formations (Pushcharovsky and others, 1988).

In Dominican Republic, Eocene multicolored arenaceous limestone is exposed west of San Cristobal, on the shore of the lake at Presa Valdesia (Valdesia dam) (Toloczyki and others, 1991).

The Cuevas Limestone of south-central Puerto Rico is calcareous conglomerate that contains algaebearing calcarenite clasts and has a maximum estimated thickness of $35 \mathrm{~m}$ (Krushensky and Schellekens, 1999).

In British Virgin Islands, the Mount Healthy Limestone member of the Tortola Formation is shallow-water-limestone lentil interbedded in breccia and tuff of the upper Shark Bay Member (mapped as the pyroclastic rocks unit [Tvc] here) of the Tortola Formation. It is light-tan to brown limestone about $15 \mathrm{~m}$ thick and consists of algal material, pelecypod fragments, and foraminifera in fine-grained calcite matrix.

"It has been mildly sheared and locally recrystallized and altered with the introduction of iron hydroxide staining. $* * *$ In addition to the outcrops in the vicinity of Mount Healthy, the limestone crops out on Rogue's Point; and is probably also present farther to the east near the contact with the batholith where a garnet, diopside, epidote, hematite skarn has developed" (Helsley, 1960).

Locally, divided into subunits Tecs and Tecd

Tecs Limestone and igneous-rock debris, shallow-water facies - In Cuba, the Caibarien Formation was described by Pushcharovsky and others (1988) as limestone, marl, and carbonate breccia. Pardo (2009) indicated that this unit is not the same as, although it is similar to, the Caibarien Formation as defined by Gulf Oil Company prior to 1959 and indicated that the Caibarien Formation is lithologically related to his (Pardo's) San Martin Formation. The Lesca Formation, as described by Pushcharovsky and others (1988), is apparently equivalent to the Caibarien Formation of Pardo (2009); the Lesca Formation consists of about $100 \mathrm{~m}$ of conglomerate and cherty limestone. The Charco Redondo Formation was described by Pardo (2009) as consisting of

"50-200 m of compact, varicolored (white, beige, yellowish brown, pinkish yellow, and yellowish red), bioclastic limestones. Intraformational limestone breccias and thickly bedded white limestones characterize its lower part. In the upper part, the brownish colors predominate, the bedding is thinner, and the bioclastic texture is dominant; some horizons consist entirely of large-foraminifera coquinas."

Pardo (2009) considered the Embarcadero Formation to be essentially his San Martin Formation, which he defined as

"tan, fine to coarse calcarenite containing abundant igneous-rock grains, interbedded with pebble conglomerate containing abundant chert fragments and with dull light-gray argillaceous limestone, which is typically shattered in splinters."

Where present, the Embarcadero Formation (that is, the San Martin Formation of Pardo, 2009) represents the first influx of igneous-rock detritus. The Universidad Formation consists of as much as $50 \mathrm{~m}$ of marl that has interbedded calcarenite at its base and scattered chert nodules; Pardo (2009) also reported that volcanic glass is a detrital component of this unit.

In Jamaica, rocks that were mapped by McFarlane and others (1984) as the Gibraltar-Bonny Gate Formation of the White Limestone Group are present in Mitchell's (2013a) Montpelier belt; these rocks correspond to Mitchell's Somerset Formation; Mitchell formally rejected the name "Gibraltar Limestone." The Somerset Formation is thin and 
“consists predominantly of pink to grey to cream foraminiferal grainstones and packstones, which locally contain a rich mollusk and coral fauna. Thin units of wackestones and carbonate mudstones may also be present *** Bedding ranges from $30 \mathrm{~cm}$ up to 2 to $5 \mathrm{~m}$ " (Mitchell, 2013a).

McFarlane and others (1984) also mapped a composite unit, the Troy/Claremont-SomersetSwanswick Formation. The Troy Formation, which reflects the earliest units of the shallow-water White Limestone Group, is generally of middle Eocene age. McFarlane and others' (1984) inclusion of the Somerset Formation, of late Eocene age in this assemblage, is at variance with usage of Mitchell (2013a). Stratigraphically, listed from lowest to uppermost, these formations are the Troy, Swanswick, and Claremont Formations, which are unconformably overlain by the Somerset Formation, which, in turn, locally rests directly on the Troy Formation. The Troy Formation is pink or brown, locally white or gray, massive to medium-bedded limestone and dolostone; in general, dolostone and recrystallized limestone dominates; dolostone is either brown, sugar-textured dolomite or pink dolomicrite. Most of formation is crystalline calcium carbonate and was interpreted by Mitchell (2013a) as dedolomitized dolostone because thin sections show replaced dolomite textures; locally, original limestone depositional fabrics, consisting of micritic limestone, are preserved (Mitchell, 2013a). The Swanswick Formation is dominantly pale white but, locally, pink or brown grainstone and subordinate packstone; bedding thickness ranges from tens of centimeters to meters, but bedding is not recognizable in many outcrops; in general, thinly bedded units are common on the platform margin, whereas thickly bedded to massive units dominate in the platform interior; bioclasts are well sorted, suggesting high-energy deposits (McFarland and others, 1984; Mitchell, 2013a). The Claremont Formation is dominantly pale pink to white calcareous mudstone and wackestone and a few thin packstone beds. Bedding thickness ranges from medium to very thick or massive; mudstone and wackestone layers are commonly very hard and brittle, whereas packstone layers are commonly softer. Dolomitization is limited for most of the formation but becomes more significant in the platform interior. Exposures of the Claremont Formation that have extensive dolomitization cannot be distinguished from exposures of the Troy Formation, other than by stratigraphic position. The presence of Fabularia verseyi suggests a probable late Eocene age (Robinson and Mitchell, 1999, cited in Mitchell, 2013a)

Tecd Limestone and igneous-rock debris, deep-water facies-The Encanto and Jabaco Formations consist of about 40 to $50 \mathrm{~m}$ of marly or argillaceous limestone and marl; the Florida Formation is about $60 \mathrm{~m}$ of calcirudite, limestone, and marl of middle Eocene age and is partially equivalent to the Vertientes Formation (Pardo, 2009). According to Pardo (2009), the Punta Brava Formation has an estimated maximum thickness of about $200 \mathrm{~m}$ of well-bedded, yellowish-cream to whitish, chalky limestone and gray to orange, fine-grained, argillaceous calcarenite that has graded bedding and contains dark igneous-rock grains; some limestone breccia is present. Pardo (2009) stated that the Punta Brava Formation is, in part, equivalent to (and similar to) the Nazareno Group (termed the Nazareno Formation here; included in the mixed clastic and lesser carbonate rocks unit [Tes] here), although it has less igneous-rock-derived material. The Punta Brava Formation was deposited in deep waters, and it unconformably overlies the Capdevila Formation (mapped as the conglomerate and sandstone unit [Tecr] here) (Pardo, 2009)

Tecr Conglomerate and sandstone (Tertiary, Eocene) — In Cuba and Puerto Rico, unit reflects erosion of older volcanic rocks both prior to and concurrently with development of the Eocene carbonate-rock units such as the limestone containing igneous-rock debris unit and its shallow- and deep-water subunits (Tec, Tecs, and Tecd, respectively).

In Cuba, most of unit is exposed in extreme northern or extreme southern Cuba, except for areally small exposures of the Marroqui Formation in central Cuba. The Capdevila Formation, exposed in northernmost Cuba, is 450 to $600 \mathrm{~m}$ (in Los Palacios Basin, can be as much as 1,680 m) of polymictic graywacke sandstone interbedded with sandy calcarenite, shale, marl, and conglomerate. According to Pardo (2009), lower part of formation consists of sandy and argillaceous rocks that have a few marl interbeds; overlying these are polymictic sandstone, argillite, conglomerate, and minor pebbly mudstone as much as $500 \mathrm{~m}$ thick. Conglomerate is poorly sorted and commonly strongly bimodal, having well-rounded boulders that mostly consist of volcanic rocks in siltstone matrix, though some pebbles of leucocratic gneiss and limestone are also present. Rarely present are tuff, agglomerate, and pink to cream, bioclastic limestone that contains abundant algae, gastropods, pelecypods, corals, and foraminifera; uppermost part of section is sandstone, siltstone, shale, and thin interbeds of marl; bedding between sedimentary sequences is rather indistinct, and they all grade into each other; graded bedding and flow structures are common, reflecting flysch deposition. In more complete sections, marl becomes more abundant toward top where unit grades into the overlying Universidad Formation (mapped as the limestone and igneous-rock debris, shallow-water subunit [Tecs] here) (Pardo, 2009). Pushcharovsky 
and others (1988) assigned a lower Eocene position to unit, whereas Pardo (2009) indicated an upper Paleocene to lower Eocene position. The Marroqui Formation of central Cuba is breccia-conglomerate, sandstone, calcarenite, limestone, and marl (Pushcharovsky and others, 1988). The Capiro Formation, exposed in extreme southeastern Cuba, was described as siltstone by Pushcharovsky and others (1988). The Camarones Formation of southern Cuba is $500 \mathrm{~m}$ of green, greenish-gray, and brown, poorly sorted, poorly stratified, massive, polymictic conglomerate and associated coarse-grained sandstone; rounded to subrounded conglomerate clasts are predominantly volcanic rocks, which are commonly silicified, 20 percent of which are felsic volcanic rocks; subordinate limestone clasts are also present; conglomerate is calcite cemented, and clasts range in size from about 10 to as much as $60 \mathrm{~cm}$ (Pardo, 2009). Conglomerate of the Boqueron Formation is closely associated with the Camarones Formation. The Farallon Grande Formation of southwestern Cuba is 50 to $1,250 \mathrm{~m}$ of polymictic, conglomeratic breccia that has angular to subangular clasts 2 to $10 \mathrm{~cm}$ in diameter and interbeds of coarse-grained sandstone and well-sorted conglomerate; sorting is poor at base, improving upward in section where rhythmic bedding is observed; most clasts are derived from volcanic rocks of the Cobre Formation (mapped as the tuff and breccia unit [Tvep] here) (Pardo, 2009). Pardo (2009) described the San Ignacio Formation of southeastern Cuba as 200 to $700 \mathrm{~m}$ of monomictic breccia that consists of fragments of greenschist and phyllite and serpentinite breccia in upper part of formation; blocks, mostly angular, are commonly 2 to $40 \mathrm{~cm}$ in diameter, though some blocks are as much as $4 \mathrm{~m}$ in size; matrix consists of sand and silt derived from rocks of greenschist facies. The San Ignacio Formation, which lies unconformably over metamorphic rocks (of the metavolcanic and meta-volcaniclastic rocks unit [Kmv]), is equivalent to the Farallon Grande Formation (Pardo, 2009). The Playa Molino Formation, which is exposed along the south coast of Cuba, consists of grayish-brown to greenish, fine-grained, finely laminated, carbonate-cemented sandstone, which may be locally metamorphosed.

The Richmond Formation of the Wagwater Group of Jamaica is apparently lower Eocene (Mann and Burke, 1990) and at least 1,000 m thick. Mann and Burke (1990) described the lower part of the Port Maria Member as about 250-m-thick, clast-supported conglomerate, thought to represent slump deposits in a submarine-fan complex. The middle part of the Roadside Member is about $800 \mathrm{~m}$ of thin-bedded sandstone, siltstone, and mudstone, in graded beds and extensively bioturbated. The Nutfield Volcanics, a subunit within the upper part of the Roadside Member, is correlated with the Newcastle Volcanic Formation (mapped as the intermediate and mafic flows and tuff unit $[\mathrm{TV}]$ here). The Albany Beds, also a subunit of the Roadside Member, consist of clast-supported conglomerate similar to the Port Maria Member and also are interpreted as slump deposits, and they include sandstone and shale blocks that are typical of the Roadside Member. The uppermost Langley Member is about $200 \mathrm{~m}$ of soft, evenly bedded, alternating dark-gray and greenish-gray, organic-rich, laminated mudstone and siltstone (Mann and Burke, 1990).

In Puerto Rico, the Monserrate Formation is volcaniclastic siltstone and sandstone interbedded with tuff and subordinate conglomerate, calcarenite, and chert; conglomerate is composed of andesite clasts (Krushensky and Schellekens, 1999). Krushensky and Schellekens (1999) locally mapped the Monserrate Formation as being interbedded with the Anon Formation, commonly calcareous tuffaceous mudstone and sandstone; breccia, tuff, and flow members of the Anon Formation are included in the andesite and basalt flows and tuff subunit [TKmv] here ate, sandstone, claystone, limestone, siltstone, and marl.

In Cuba, many widely distributed, formal geologic formations are represented by this map unit; the following 14 units of Pushcharovsky and others (1988) are included here, supplemented by descriptions by Pardo (2009) and others: (1) The Bijabo Formation, 150 to $300 \mathrm{~m}$ of thin-bedded, loosely consolidated, brown sandstone, shale, and conglomerate interbedded with sandy limestone (Pardo, 2009). (2) The combined Blanquizar and Ranchuel Formations, consisting of conglomerate, limestone, marl, and sandstone, and the Ferrer Formation, $150 \mathrm{~m}$ of medium-bedded, loosely consolidated conglomerate, sandstone, and marl; conglomerate clasts are mostly limestone but include lesser quartz and schist cobbles and boulders (Pardo, 2009). (3) The Guaicanamar Formation, consisting of clayey limestone, marl, sandstone, and siltstone. (4) The Jicotea Formation, consisting of marl, siltstone, sandstone, and conglomerate. (5) The Maraguán Formation, $100 \mathrm{~m}$ of interbedded conglomerate, sandstone, siltstone, and marl; likely derived from erosion of Cretaceous granitic rocks (mapped as unit Kgu here) and ophiolite-associated rocks of the ultramafic rocks and associated rocks unit (Mzum). (6) The Meyer Formation, consisting of breccia, conglomerate, sandstone, limestone, and marl. (7) The Nazareno Formation, which consists of, according Pardo (2009), possibly as much as $700 \mathrm{~m}$ of interbedded gray argillaceous marl, fine-grained argillaceous limestone, minor pink to reddish-brown laminated 
siltstone to fine-grained sandstone, and gray shale; distribution of lithologic components is variable, but limestone and limestone-siltstone-shale sequences dominate; formation is lithologically variable and has been called a group that may be able to be divided into discrete formations (Albear Franquiz and Iturralde-Vinent, 1985). (8) The Ochoa Formation, defined by Pushcharovsky and others (1988) as conglomerate, sandstone, limestone, marl, siltstone, and claystone; Pardo (2009) suggested that formation includes other formations that include Pardo's (2009) Vega, Vicente, and Falcon Formations. (9) The Peñón Formation, consisting of breccia, conglomerate, and limestone; spatially associated with ophiolite-associated rocks of the ultramafic rocks and associated rocks unit (Mzum). (10) The Piedras Formation, consisting of conglomerate, sandstone, limestone, and conglomeratic breccia. (11) The San Luis Formation, as described by Pardo (2009), consists of $700 \mathrm{~m}$ of a wide variety of clastic and carbonate rocks; thin- to medium-thickness, well-bedded, gray, brownish-gray, and brown, fine- to mediumgrained sandstone constitutes 90 percent of the formation, where most fragments are derived from volcaniclastic rocks of the Cobre Formation (mapped as the tuff and breccia unit [Tvep] here); green to greenish-gray or brown conglomerate is poorly sorted and polymictic, consisting mostly of volcanicrock fragments and limestone; siltstone, which is shaly, calcareous, and locally sandy and contains sparse carbonized plant fragments, is gray when fresh and beige to brown when weathered; white, laminated, marly limestone is found generally at base of formation but also can be found higher in formation as well; cream-colored, sandy and bioclastic-sandy limestone also is present. (12) The Saramaguacán Formation, consisting of limestone, marl, clayey sandstone, and siltstone. (13) The Siguaney (or Loma Iguara) Formation, about $90 \mathrm{~m}$ of massive, thick-bedded, porcelaneous, fine calcarenite interbedded with massive limestone conglomerate (Pardo, 2009). (14) The Monte Alto Formation, described by Pushcharovsky and others (1988) and shown as Upper Cretaceous, according to Pardo (2009), is a few tens of meters of marl; Pardo (2009) reported presence of fossils that generally indicate that unit is upper Eocene.

In Dominican Republic, small areas of sandstone and marl of middle Eocene age are exposed west of San Cristobal along west shore of lake at Presa Valdesia dam and also about $40 \mathrm{~km}$ to north (Toloczyki and others, 1991).

In Jamaica, the Chapelton Formation of the Yellow Limestone Group has been divided into multiple members; uppermost member is middle Eocene, impure, fossiliferous limestone, which overlies middle and lower Eocene, gypsum-bearing clay member or sandstone and clay member; limestone and also arkosic sandstone and conglomerate members are interbedded with lower members (Donovan, 2002). The Font Hill Formation (or Font Hill Limestone) is a cream-colored, thinly bedded, marly limestone that contains interbedded clastic limestone; coarse breccia, present in upper part of section, is commonly graded, containing blocks of the Richmond Formation (mapped as the volcanic clast-bearing rocks unit [Tpcr] here) as large as $60 \mathrm{~cm}$, as well as local exotic masses of the Richmond Formation, some more than $15 \mathrm{~m}$ across, and local exotic fragments of the Wagwater Formation (called the Wagwater Conglomerate by James, 2005); breccia represents olistostrome deposits.

In Puerto Rico, the Guayo Formation in the south-central part of the island is conglomerate and subordinate sandstone and siltstone; clasts include volcanic rocks similar to the Anon Formation (mapped as the conglomerate and sandstone unit [Tecr] here) and limestone similar to the Cuevas Limestone (mapped as the limestone containing igneous-rock debris unit [Tec] here) (Krushensky and Schellekens, 1999). The Río Culebrinas Formation, consisting of mudstone and limestone, breccia, tuff, and volcanic-clast sandstone and mudstone, of northwestern Puerto Rico is as much as $3,000 \mathrm{~m}$ thick (Krushensky and Schellekens, 1999)

Tvcv Mixed carbonate and clastic rocks and tuff (Tertiary, Eocene) - In Cuba, two formations are included in this unit, the Castillo de Los Indios and the Barrancas Formations. The Castillo de Los Indios Formation is exposed in extreme southeastern Cuba and in a small area in northern Cuba northeast of Güines; it typically consists of $70 \mathrm{~m}$, but as much as $250 \mathrm{~m}$, of thin- to medium-bedded, lithic and lithicvitric tuff. The vitric tuff consists of somewhat altered, fine- to medium-sized volcanic-glass fragments, though locally they can be as much as $8 \mathrm{~cm}$ in diameter. Distributed throughout are limestone, marl, and light-gray to yellowish-white, thin-bedded siltstone; locally, limestone is dominant (Pardo, 2009). The Barrancas Formation is 60 to $100 \mathrm{~m}$ of crystal-vitric and vitric, rhyolite-rhyodacite tuff. Lesser white marl, cream-colored, well-sorted, tuffaceous, and calcareous sandstone, white bioclastic limestone, and calcilutite also are present (Pardo, 2009)

Tepc Brecciated carbonate and clastic rocks (Tertiary, middle Eocene to Paleocene) - Unit contains the products of erosion of the Cretaceous volcanic arc; unit consists of sandstone, conglomerate, claystone, marl, limestone, and locally calcareous breccia and commonly includes (or consists entirely of) olistostrome deposits; primarily exposed in Cuba, particularly northern Cuba. Pushcharovsky and others (1988) 
combined several named formations into some of their individual map units. Additionally, according to Pardo (2009) some controversy concerning unit names exists.

In Cuba, the most areally extensive formation described by Pushcharovsky and others (1988) is the Pica Pica Formation (or the Manacas Formation). Pardo (2009) described the Manacas Formation as tens of meters to as much as $500 \mathrm{~m}$ of shale, sandstone, and limestone in lower part and chaotic megaconglomerate and breccia (olistostromes) in upper part; Pardo (2009) stated that

"there have been differences of opinion as to the classification of these deposits. They have been described under the names of Pinar Group, Manacas, Pica Pica, and Quinones[*1] Formations, Vieja wildflysch (also referred to as the "Big Boulder bed"), and Canaletes chert. Hatten (1957, cited by Pardo, 2009) named the Pinar Group and divided it into the Manacas Formation, the Vieja wildflysch (Big Boulder bed), and the Canaletes chert."

Hatten (1957) described the marine Manacas Formation as predominantly graywacke and lithic wacke; though poorly sorted with poorly developed bedding, locally graded bedding is present; greenish-gray shale horizons are commonly interbedded in graywacke; some have been reported to be tuffaceous. In general, unit consists of angular quartz and feldspar grains and fine volcanic-rock fragments, enclosed in matrix of silt and clay; also present is pebbly conglomerate that contains angular limestone clasts, clasts of dolostone, and rounded clasts of olivine basalt and intermediate-composition porphyritic rocks. The Vieja wildflysch is made up of dark-greenish-gray to grayish-blue-green, highly sheared, serpentinized rock that encloses exotic blocks as large as 2 to $3 \mathrm{~m}$ in diameter of amphibolite, actinolite-garnet schist, and hornblende-quartz-bearing rocks. Hatten's (1957) Canalete chert is generally dark gray but weathers to light gray; bedding is generally well developed, having uniform beds near 1 $\mathrm{cm}$ in thickness; between individual beds is found thin (approximately 2 to $3 \mathrm{~mm}$ ) siliceous shale beds; radiolaria are abundant to common in chert and shale. Pardo (2009) considered the Pica Pica Formation to be a member of the Manacas Formation and described it as consisting of a few meters to $100 \mathrm{~m}$ of interbedded, yellow-weathering clay-shale, graywacke sandstone, marly limestone, and detrital limestone. Closely associated spatially with the Manacas Formation, and locally grading into it, is micritic and shaly limestone of the Ancón Formation. Also present in northern Cuba (and associated spatially with these other units), the Mercedes, Madruga, Via Crucis, Apolo, and Alkazar Formations were mapped by Pushcharovsky and others (1988) as a single unit; described as sandstone, conglomerate, claystone, marl, and limestone, all considered to be deep-water flysch deposits. In southeastern Cuba, Pushcharovsky and others (1988) mapped the Embarcadero Oriental Formation as 50 to $300 \mathrm{~m}$ of limestone- and dolostone-bearing conglomeratic breccia that consists of 90 percent limestone (various types found in older carbonate platform), 6 to 8 percent dolostone, and 2 to 4 percent chert; percentage of igneous-rock clasts is very small (Pardo, 2009). In central Cuba, breccia and limestone of the Grande Formation is exposed in a thin, linear belt along contact between mélange of unit Tmo and Cretaceous limestone of unit Kcr.

In eastern Dominican Republic, Paleocene limestone is found locally in fault-bounded slivers or as isolated exposures surrounded by Cretaceous andesitic volcanic rocks of unit Kevi.

In Jamaica, the Halberstadt Limestone is light-gray reef limestone, in bodies as much as $100 \mathrm{~m}$ thick (Mann and Burke, 1990); the Halberstadt Limestone and the equivalent Chepstow Formation and Woodford Limestone, the latter of which is hard, splintery, gray to black, impure limestone, are members of the Wagwater Formation, ${ }^{2}$ which is thought to represent a transverse intra-arc rift zone (Mann and Burke, 1990; Hastie, 2007).

In north-central Puerto Rico, the Corozal Limestone and the Carreras Siltstone are both exposed. The Corozal Limestone consists of lenticular beds of light-gray limestone and grayish-red limestone breccia (Nelson, 1966), about 150 m thick (Krushensky and Schellekens, 1999). The Carreras Siltstone is medium-dark-gray siltstone that contains thin- to medium-bedded, light-colored bands or laminae of mixed reworked ash and epiclastic particles. Unit is dense and highly calcareous, such that some beds might be considered impure limestone. Unit locally grades downward into arkosic conglomerate consisting of granodiorite clasts; maximum estimated thickness, $600 \mathrm{~m}$ (Berryhill, 1965; Krushensky and Schellekens, 1999)

${ }^{1}$ Within quotations from Pardo (2009), here and throughout report, single asterisk [in brackets] indicates that unit name was used in 1950s by Gulf Oil Co. geologists but may or may not be in current use.

${ }^{2}$ Some sources, such as McFarlane and others (1984), called this formation the Wagwater Group; however, Mitchell and others (2016) reported the abandonment of the Wagwater Group name and formal acceptance of the Wagwater Formation name. Additionally, the Halberstadt Limestone was abandoned as a formation name; the Good Hope Limestone was suggested as an alternative (Mitchell and others, 2016). 
Tpcr Volcanic clast-bearing rocks (Tertiary, lower Eocene to Paleocene) - Clastic rocks exposed in Jamaica and Puerto Rico; unit includes the Wagwater Formation in Jamaica and the Palmarejo and Raspaldo Formations and the Rio Piedras Siltstone in Puerto Rico.

In Jamaica, the Wagwater Formation has been divided into several members (Mann and Burke, 1990). Lowermost, the Ginger River Member, is very poorly sorted, purple, polymictic clast-supported conglomerate that contains metamorphic- and volcanic-rock clasts ranging in size from pebbles to boulders as much as $3 \mathrm{~m}$ in diameter, all in a muddy-sand matrix and in beds as much as $10 \mathrm{~m}$ thick (Mann and Burke, 1990). Locally, conglomeratic limestone beds are present. Also present are the Halberstadt and Woodford Limestone members (described in the brecciated carbonate and clastic rocks unit [Tepc] above). Another major member is the Pencar River Member, $300 \mathrm{~m}$ of brownish-dark-gray to green, coarse sandstone and conglomerate, which has ripple marks present on some bedding surfaces (Mann and Burke, 1990). The Dry River Member, uppermost member of the Wagwater Formation, consists mainly of poorly sorted, purple, polymictic conglomerate; lithologically similar to conglomerate of the Ginger River Member, being clast supported and having a poorly sorted, muddy-sand matrix; in contrast to the Ginger River Member, however, clasts include granodiorite, not present in the Ginger River Member. "Bedding is rarely seen except where lenses of coarse sandstone weakly define bedding" (Mann and Burke, 1990). The Garlands/Summerfield Formations (McFarlane and others, 1984) or the Summerfield Group of Hastie (2007) is exposed in fault blocks in the White Limestone Group (mapped as the limestone and igneous-rock debris, shallow-water facies subunit [Tecs] here). As described by Hastie (2007), the Summerfield Group is a shallowing-upward succession of marine to terrestrial volcaniclastic sedimentary rocks that has been interpreted as a prograding braided delta (Mitchell, 2000, cited in Hastie, 2007). Mitchell and Blissett (2001, cited in Hastie, 2007) recognized four formations: the Green River Formation, evenly and thinly bedded volcaniclastic sandstone; the Peckham Formation, massive sandstone; the Mahoe River Formation, volcaniclastic sandstone and conglomerate; and the Waterworks Formation, thick ash-flow tuff or ignimbrite. Hastie (2007) also reported a second thick ignimbrite within the Mahoe River Formation that he called the Bronte Tuff Member; McFarlane and others (1984) mapped the Garlands/Summerfield unit as being Maastrichtian, whereas Hastie indicated it is Paleocene.

In Puerto Rico, the Palmarejo Formation in the north-central part of the island consists of volcanic sandstone interbedded with siltstone as much as $370 \mathrm{~m}$ thick. The Raspaldo Formation, on the south coast, contains graded tuffaceous mudstone and tuff at least $600 \mathrm{~m}$ thick. The Rio Piedras Siltstone in the northeastern part of the island consists of volcanic sandstone, siltstone, and basal conglomerate as much as $1,400 \mathrm{~m}$ thick

Tvg Sedimentary rocks and tuff (Tertiary, lower Eocene to Paleocene)-The Pilón Formation of Cuba, exposed in southern Cuba, north of Pilón (Pushcharovsky and others, 1988), was described by Pardo (2009) as more than 2,000 $\mathrm{m}$ of lower banded calcareous tuff overlain by graywacke and mediumgrained sandstone or conglomerate composed of volcanic-rock fragments, in turn overlain by massive limestone containing volcanic-rock fragments in its upper part; Pardo (2009) stated that it is reported to contain abundant Cenomanian-Turonian reworked clasts. The Vigia Oriental Formation of Pushcharovsky and others (1988) (or, the Vigia Formation of Pardo, 2009), exposed near Holguín in southeastern Cuba, is described by Pardo as being as much as $700 \mathrm{~m}$ of mostly igneous-rock-derived clastic rocks, detrital limestone, and tuff. Lower part of formation is interbedded layers of green to grayishgreen mafic tuff, limestone, and well-bedded, volcanic-rock-derived, fine- to coarse-grained graywacke and mudstone; upper part is white to grayish-white, thin-bedded, well-bedded, calcareous, commonly silicified or zeolitized tuff and radiolaria-bearing marl and bentonite, as well as white to grayish-white, porphyritic rhyodacite and greenish-gray, dense rhyodacitic tuff (Pardo, 2009); unit contains a rich foraminiferal fauna that suggests an upper Paleocene to middle Eocene age.

In Puerto Rico, the Ortiz Formation "consists of calcareous, thick-bedded coarse sandstone with interbeds of dusky-red shale at the base, overlain by thin conglomerate and varicolored volcanic sandstone and siltstone and pale-green tuff' (Nelson, 1966). It conformably overlies the Corozal Limestone (mapped as the brecciated carbonate and clastic rocks unit [Tepc] here); because upper part is not exposed owing to faulting, maximum thickness is estimated at $600 \mathrm{~m}$; age of Paleocene or Eocene is based on age of the underlying Corozal Limestone (Nelson, 1966; Krushensky and Schellekens, 1999)

\section{TERTIARY TO CRETACEOUS SEDIMENTARY ROCKS}

TKfs Flysch (lower Tertiary to Upper Cretaceous) - Exposed in northwestern Cuba, flysch-like rocks of the Cacarajícara and Peñalver Formations consist of calcareous and clastic mega-turbidites that transition upward from calcirudite to calcarenite and calcilutite (Pushcharovsky and others, 1988); clasts are largely calcareous but contain minor igneous-rock debris. 
In Dominican Republic, flysch consists of sandstone, gray to violet, thin-bedded pelagic limestone, and marly sandstone containing interbedded conglomerate and olistoliths; exposed in the central part of the country, as well as adjacent to the border with Haiti (Toloczyki and Raminez, 1991).

In Haiti, adjoining the flysch unit in Dominican Republic, is a unit that Vila and others (1985) called the "Flysch of the Massif du Nord" (mapped there as "cF"); Vila and others (1985) described their "cF" flysch unit as mostly schistose argillite, mudstone, sandstone, conglomerate, and limestone turbidites of Late Cretaceous age; it is distinct from another Haitian flysch of presumed older Cretaceous age mapped by Vila and others (1985) as "cbl"; included in the siltstone that includes the local olistostrome deposits subunit [Kso] here. Vila and others (1985) described their "cF" flysch unit as constituting northwest-southeast-trending band that extends into Dominican Republic. Vila and others (1985) also mapped (conterminous with their unit "cF") a low-grade metamorphic-rock unit (their unit "Ms") that they described as a polyphase schistose complex (shale, sandstone, schist) derived from sandy and clay-rich pelitic rocks by weak dynamic metamorphism.

Age of this unit is uppermost Cretaceous to lowermost Tertiary

Mixed volcanic and sedimentary rocks (Tertiary? to Cretaceous, Campanian or lower?) — In southwestern Puerto Rico, consists of mixed volcanic and sedimentary rocks of early Tertiary and Late Cretaceous age, interbedded and interleaved in such a manner that Krushensky and Schellekens (1999) commonly could not separate them at map scale and, as a consequence, created several units that combine the Anon, Yauco, Maricao, and Lago Garzas Formations, in various combinations.

Herein, we divided unit into three subunits: we assigned largely sedimentary rocks to the conglomerate, sandstone, and claystone subunit (TKcs); largely volcanic rocks to the andesite and basalt flows and tuff subunit (TKmv); and truly intermixed rocks to the mixed volcanic and clastic rocks subunit (TKvc)

TKcs Conglomerate, sandstone, and claystone-Volcaniclastic sandstone, siltstone, claystone, conglomerate, and, locally, limestone of the Yauco Formation is exposed in southwestern Puerto Rico (Krushensky and Schellekens, 1999); formation is locally interbedded with the Maricao, Anon, and Lago Garzas Formations (included in the mixed volcanic and clastic rocks subunit [TKvc] here), which contain fossils of Tertiary age and, therefore, may indicate that age of the Yauco Formation may be Tertiary to Late Cretaceous; however, fossils of Tertiary age are not known from the Yauco Formation; estimated thickness, more than $1,200 \mathrm{~m}$

TKve Mixed volcanic and clastic rocks-Exposed in southern Cuba and Puerto Rico, unit is similar to the conglomerate, sandstone, and claystone subunit (TKcs) above, with the addition of tuffaceous deposits that are locally altered to bentonite.

In Cuba, the Micara Formation consists of undivided clastic sedimentary rocks that include volcaniclastic sandstone and conglomerate and olistostrome beds (Pushcharovsky and others, 1988); according to Pardo (2009), formation is dark-gray, greenish-gray, and dark-green, fine- to medium-bedded sandstone and siltstone and interbeds of conglomerate and dolomitized limestone; graded bedding and crossbedding are common. The sandstone, which is fine- to coarse-grained, consists of subrounded rock fragments, plagioclase, quartz, chalcedony, calcite, and ultramafic rocks, in a calcareous matrix. The siltstone, which is gray, is made up of rock fragments, plagioclase, quartz, and calcite, in a fine-grained matrix. Contact between sandstone and siltstone is commonly sharp, erosional, and wavy. Conglomerate clasts, which are rounded to subangular and as much as $20 \mathrm{~cm}$ in diameter, consist of volcanic rocks, gabbro, diorite porphyry, limestone, and, locally, serpentinite, in a sandy matrix. A rich nannoplankton assemblage suggests a Maastrichtian to Campanian age. The Micara Formation, which appears to have been deposited as flysch in open water as result of erosion of an advancing thrust front (Pardo, 2009), is found under the major ultramafic thrust sheet that covers a large part of southeastern Oriente region (Pardo, 2009).

In north-central Puerto Rico, the Cibuco Formation, as much as 2,000 m thick, consists of conglomerate and interbedded volcanic-clast sandstone, siltstone, and tuff. Also included here are multiple combined units of Krushensky and Schellekens (1999). Unit "TKay" (the interbedded Anon and Yauco Formations) is described as "calcareous and foraminiferal mudstone, siltstone, and claystone of the Yauco Formation interbedded with tuff, tuffaceous sandstone-mudstone and rarely conglomerate of the Anon Formation" (Krushensky and Schellekens, 1999). Other units of Krushensky and Schellekens (1999) added basalt of the Maricao Formation ("TKaym") to this mix, which was described as "dacitic tuff, tuffaceous sandstone, and breccia of the Anon Formation; irregularly interbedded with Yauco; and subordinate interbedded trachybasalt of the Maricao Formation" (Krushensky and Schellekens, 1999). Another mixed unit of Krushensky and Schellekens (1999) ("TKly") combined the Lago Garzas Formation, a mixed volcanic- and sedimentary-rock unit, with the Yauco Formation (Krushensky and 
Schellekens, 1999). Other units of Krushensky and Schellekens (1999) (“TKam”, “TKmy”) contained variable contributions of the Anon, Maricao, and Yauco Formations in each unit

TKmv Andesite and basalt flows and tuff-Restricted to Puerto Rico, unit constitutes dominantly volcanic-rock component of Krushensky and Schellekens' (1999) mixed Upper Cretaceous and lower Tertiary units (their units "TKal", "TKlam", “TKm", "TKmly"). Includes the Maricao Formation, which consists of dark-green volcaniclastic breccia (clasts contain augite and plagioclase phenocrysts), thick-bedded to massive, coarse-grained basaltic tuff and tuff breccia, and thin-bedded, coarse-grained tuff (McIntyre and others, 1970; Krushensky and Curet, 1984). Also includes the breccia and tuffaceous members of the Anon Formation, mentioned above as being interbedded with the Yauco Formation, a complex of interbedded dacite and lesser andesite flows, pyroclastic rocks, and minor hypabyssal intrusive rocks. The mudstone and volcanic-clast sandstone (Mattson, 1967) of the Anon Formation in its type section appears to be of Eocene age; nonetheless, it is locally interbedded with the Cretaceous Yauco, Lago Garzas, and Maricao Formations. Unit here also includes andesite porphyries, largely exposed in western Puerto Rico but also locally exposed in northeastern Puerto Rico. Northeastern porphyries are lightgray to light-purplish-gray or light-bluish-gray, greenish-gray, massive porphyritic augite hornblendeandesite porphyry and locally include basalt and dacite; locally grades into diorite and weathers to a light purplish-gray saprolite product (Krushensky and Schellekens, 1999); they overlie Late Cretaceous sedimentary and volcanic rocks of the sedimentary and volcanic rocks subunit and the andesitic breccia, flows, and tuff subunit (Klsv and Kvl, respectively, here)

TKI Limestone, marl, and tuff (Tertiary, Paleocene and Cretaceous, Maastrichtian) - Several dominantly limestone units of Paleocene to Late Cretaceous age are present in small outcrop areas throughout Cuba (Pushcharovsky and others, 1988). Among these are the Cocos Formation, which consists of marl, micritic and detrital limestone, fine-grained polymictic sandstone, and bentonitic clay; the Fomento Formation, which consists of marl, siltstone, and fine-grained, clayey limestone interbedded with clayey and zeolitized tuff; the Gran Tierra Formation, which consists of carbonate-cemented volcanicclast conglomerate that grades into fragmental limestone and interbeds of calcareous volcaniclastic and tuffaceous sandstone, siltstone, tuffite, marl, and tuff; the Santa Clara Formation, which consists of limestone, marl, and tuff; and the Vaqueria Formation, which consists of limestone, marl, brecciaconglomerate, and tuff (Pushcharovsky and others, 1988). In the Santa Clara Formation and also in the Vaqueria Formation, the Cretaceous-Tertiary boundary has been identified, and impact-generated material has been found (Pardo, 2009)

\section{CRETACEOUS SEDIMENTARY ROCKS}

Ksvr Mixed sedimentary and volcanic rocks (Cretaceous) - Exposed only on the island of Hispaniola; includes the Tireo Formation of Dominican Republic (Toloczyki and others, 1991) and several limestone- and tuff-rich units in Haiti (Vila and others, 1985). However, subdivisions of this general unit are present in Cuba, Jamaica, and Puerto Rico (as described in the sedimentary and volcanic rocks subunit [KIsv] description here). Limestone and chert are important components of unit in both countries on the island of Hispaniola, as are tuff and volcaniclastic rocks. In Haiti, Vila and others' (1985) unit "cc" is included the Daco Limestone of Massif des Montagnes Noires, which consists of pelagic limestone that contains chert interbeds; fine-grained tuff, chert, and radiolarian chert of the Vache Formation near Jacmel; and Upper Cretaceous epipelagic limestone of the Macaya Formation (Vila and others, 1985). Age of the Daco Limestone is not well constrained: one of Vila's (Vila and others, 1985) coauthors, Butterlin, suggested that region is made up of middle Eocene volcanic tuff and volcanic-clast breccia alternating with limestone beds of the Perodin Formation, which is reminiscent of the Cobre Formation (the tuff and breccia unit [Tvep] here) of Sierra Maestra in Cuba (Butterlin, 1960, cited in Vila and others, 1985). The Vache Formation is white or beige, fossiliferous chert that contains thin, interbedded layers of wellsorted volcanic-rock-detritus turbidite and rests tectonically on olistostrome deposits of the siltstone and local olistostrome deposits subunit (Kso) north of Jacmel. Locally, divided into subunit Klsv

Klsv Sedimentary and volcanic rocks (Upper Cretaceous) - In north-central Cuba, includes volcaniclastic rocks, tuff, marl, claystone, intermediate- to mafic-composition volcanic rocks, and reef limestone of the Carlota Formation; also includes volcaniclastic rocks, tuff, basalt, sandstone, and limestone of the Jarao Formation (Pushcharovsky and others, 1988).

In Dominican Republic, Toloczyki and others (1991) reported poorly defined unit of "Late Cretaceous volcano-sedimentary rocks" in eastern part of country. We also include here unit defined by Toloczyki and others (1991) simply as "flysch."

In Puerto Rico, several formal stratigraphic units are included here; common among them are andesitic to basaltic, volcaniclastic sandstone, siltstone, and breccia, as well as flows that may be 
pillowed; less common are conglomerate, tuff, calcarenite, limestone, and limestone conglomerate. In southwestern Puerto Rico, includes the Sabana Grande Formation (note that the Sabana Grande Formation of Cuba is of similar age but is largely volcanic). In south-central Puerto Rico, includes the Maravillas Formation (most limestone rich of Puerto Rican units here). In central Puerto Rico, includes the Pozas and Vista Alegre Formations. In northeastern Puerto Rico, the Guynabo Formation is found to the west; the Hato Puerco Formation, which is found farther east, overlies the Infierno Formation (Krushensky and Schellekens, 1999); these formations are uniformly thick, ranging from as much as $900 \mathrm{~m}$ (Infierno Formation) to 2,600 m (Hato Puerco Formation). Limestone is most common in the units of central Puerto Rico.

In Jamaica, McFarlane and others (1984) mapped their Cretaceous sedimentary-rock unit "Ku", which, according to Arden (1975), likely is rudist-bearing limestone and interbedded shale and siltstone of Maastrichtian age

$\mathrm{Kcr} \quad$ Limestone and chert (Cretaceous) - Dominantly consists of limestone; includes carbonate units of broadly defined Cretaceous age. In southern Cuba, includes the Gibara Formation of Maastrichtian(?) to Aptian age; Pardo (2009) described formation as being 700 to $800 \mathrm{~m}$ of limestone, although Pushcharovsky and others (1988) suggested that thickness is as much as 6,000 m; lower Aptian to Albian part of formation is brownish-white, compact, medium-bedded, crystalline limestone and interbedded yellowish-white, sometimes laminated, hard, microcrystalline limestone; slight angular discordance separates upper (possibly Turonian to Maastrichtian) part of formation, consisting of massive, crystalline, medium- to coarse-grained, yellowish-gray limestone, which contains abundant rudist remains, that transitions upward to yellowish-white, dense, microcrystalline pelagic limestone; beds of dolostone and dolomitic limestone are present, most persistent of which has been named the Jobal Formation (Pardo, 2009). Most widespread of Cretaceous limestone units included here was mapped as the Remedios Formation by Pushcharovsky and others (1988); however, Pardo (2009) indicated that, as mapped, formation includes all Cretaceous and Jurassic carbonate rocks, in what Pushcharovsky and others (1988) called the "Remedios structural zone" of central Cuba. As traditionally defined, the Remedios Formation is of Maastrichtian age and consists of about $470 \mathrm{~m}$ of dolostone overlying about $260 \mathrm{~m}$ of porcelaneous limestone. As defined by Pushcharovsky and others (1988), formation ranges in age to Albian, although it includes rocks mapped as the Vinas Group that range from Cenomanian to Upper Jurassic (Pardo, 2009). In a small area northeast of the Remedios Formation is the Guaney Formation of Pushcharovsky and others (1988), defined as limestone, micrite, biomicrite, and marl. In northern Cuba, Pushcharovsky and others (1988) mapped the Sierra Azul Formation, consisting of undivided limestone, argillite, and chert and ranging in age throughout much of the Cretaceous period; however, Pardo (2009) considered the Sierra Azul Formation to be an invalid unit, its rocks being assigned to several other units.

In central Dominican Republic, very small exposures of Cretaceous limestone were mapped by Toloczyki and others (1991). Limestone described as being of upper Lower Cretaceous age is exposed in eastern Dominican Republic.

In Haiti, the Macaya Formation (unit "c" of Vila and others, 1985) forms massive karst cliffs of Upper Cretaceous (Maastrichtian to Coniacian) epipelagic, biomicrite limestone that is associated with green and red radiolarian chert and thin siliceous interbeds (Butterlin, 1960, cited in Vila and others, 1985).

Locally, divided into subunits Klc, Kelc, and Kec

KIC Limestone and limestone conglomerate (Upper Cretaceous, Maastrichtian and Campanian) —Many Upper Cretaceous carbonate units are common in the Greater Antilles, including northern and central Cuba, eastern Dominican Republic, and western Puerto Rico, and on Saint Croix in the U.S. Virgin Islands.

In Cuba, included here are multiple units as mapped by Pushcharovsky and others (1988): (1) 70 to $100 \mathrm{~m}$ of dolostone and dolomitic limestone of the El Jobal Formation (Pardo, 2009); (2) several dozen meters of silicified, porcelaneous limestone of the Lindero Formation, which was considered the Lindero Member of the Iberia Formation by Pardo (2009) (the Iberia Formation of Cuba is mapped as subunit Kvib here); (3) massive limestone of the Tinajita Formation, in southern Cuba; (4) areally extensive, 300-m-thick, fossiliferous limestone, calcirudite, marl, and sandstone of the Jimaguayu Formation, also in southern Cuba; and (5) the Lutgarda Formation, in central Cuba, consisting of 55 $\mathrm{m}$ of thin- to medium-bedded calcarenite and calcirudite, bright red and brown chert beds and nodules, very fine, detrital to porcelaneous white limestone, greenish-blue clay, and characteristic sugary-white limestone or coquina that consists exclusively of small, broken rudist fragments (Pardo, 2009). The basal limestone of the Lutgarda Formation is strongly stained with manganese, yielding a pink to black color (Pardo, 2009). The Amaro Formation, which has been correlated with the Lutgarda Formation 
by Pardo (2009), is dominantly thick-bedded limestone and, in its basal part, conglomerate that contains fragments of chert and calcarenite (Pardo, 2009). Both the Amaro Formation and the Lutgarda Formation are of turbidite origin; turbidites in the Lutgarda Formation are interbedded with pelagic sedimentary rocks (Pardo, 2009).

In eastern Dominican Republic, Toloczyki and others (1991) reported Upper Cretaceous limestone overlying rocks of the intermediate-composition volcanic rocks subunit (Kevi).

In Jamaica are quite a few Upper Cretaceous limestone units. McFarlane and others (1984) mapped the Rio Grande Limestone as part of the Bellevue Formation and indicated it is Maastrichtian; however, Hastie (2007) indicated that the Rio Grande Limestone is the upper member of the underlying Back Rio Grande Formation and is Campanian. The Guinea Corn Limestone (or the Guinea Corn Formation) has a lower part composed of interbedded greenish-gray mudstone, siltstone, and rubbly limestone, succeeded by massive, rubbly limestone that has a few siltstone beds; the upper part is mudstone and graded sandstone (Hastie, 2007). Arden (1975) described the Clifton Limestone member of the Hanover Formation as being "of reef origin and is composed largely of corals and rudists. Among the rudists are species of Barrettia, indicative of early Campanian age." Arden (1975) described four limestone formations, separated by mudstone and siltstone, that are present in the Calton Hill and Maldon Inliers in western Jamaica; we believe that these include the Calton Hill Limestone, the Maldon Limestone, the Stapleton Limestone, and the Titanosarcolites Limestone.

In Puerto Rico are two Upper Cretaceous limestone units on the western part of island. The Penoñes Limestone, exposed in a few small outcrops in central western Puerto Rico, is pale-gray, massive, thick-bedded, fossil-bearing limestone and limestone breccia (Curet, 1986); Krushensky and Schellekens (1999) reported that the limestone contains minor volcanic-lithic and volcanic-mineral clasts; according to Curet (1986), limestone bodies are locally intruded by small stocks and formed part of a gravity-glide block that came to rest on intrusive porphyritic-pyroxene andesite-diorite. The (age-equivalent) Cotui Limestone, which is more extensively exposed in southwestern Puerto Rico, was described by Krushensky and Schellekens (1999) as being as much as $75 \mathrm{~m}$ of massive limestone that has basal conglomerate containing volcanic clasts from the underlying Lajas Formation (mapped as the basalt, pillowed and nonpillowed flows, breccia, and tuff subunit [KImv] here). A hard, gray limestone that is possibly equivalent to the Penoñes Limestone is sparsely exposed in the eastern part of Isla de Vieques (Vieques Island) and on other smaller offshore islands (Learned and others, 1973).

On northern Saint Croix in the U.S. Virgin Islands, a thin $(15 \mathrm{~m})$, resistant limestone and volcanicclast pebble-conglomerate bed, known as the Clairmont Member of the Judith Fancy Formation, is exposed; it can be mapped for about $3 \mathrm{~km}$ and is considered Campanian (Whetten, 1966)

Kelc Limestone and minor calcarenite (Cretaceous, Turonian to Hauterivian) - Only exposed in Cuba, the largest exposure of unit is the Carmita and Mata Formations in central Cuba, consisting of stratified, biomicritic and arenaceous limestone, chert, marl, and, locally, breccia-conglomerate (Pushcharovsky and others, 1988). In northern Cuba, the Guajaibon Formation consists of massive, locally dolomitized limestone and biomicritic calcarenite (Pushcharovsky and others, 1988). The Pons Formation was described by Pushcharovsky and others (1988) as limestone, micritic limestone, and interbeds of siliceous rocks of Paleocene to Hauterivian age; however, Pardo (2009) indicated that the Pons Formation is no younger than Campanian and more likely is no younger than Turonian

Kec Carbonate rocks, including biomicritic limestone (Lower Cretaceous, Barremian to Berriasian) - In Cuba, two formations, the Lucas and Margarita Formations, both of biomicritic limestone, form this unit; the Lucas Formation also contains calcareous argillite; the Margarita Formation also has minor chert interbeds (Pushcharovsky and others, 1988).

In Jamaica, the Devil's Race Course Group includes several limestone formations, such as the Benbow, Copper, Phillipsbury, and Jubilee Limestones (McFarlane and others, 1984)

$\mathrm{Kcgl}$ Volcaniclastic conglomerate (Cretaceous, Maastrichtian to Albian)-Though exposed in Cuba and Jamaica, most extensive exposures of this unit are in Puerto Rico.

In central Cuba, the Jucillo Formation is volcanic-clast pebble-conglomerate that ranges in thickness from 0 to $900 \mathrm{~m}$ (Pardo, 2009). Pushcharovsky and others (1988) considered it lower Eocene; however, although it is barren of organisms, Pardo (2009) considered it Maastrichtian because of its stratigraphic position and because reef limestone in its upper part grades into the Maastrichtian Isabel Formation (mapped as the limestone and limestone conglomerate subunit [KIc] here).

In Jamaica, the Slippery Rock Formation, exposed in Central Inlier, is red, brown, or gray conglomerate and sandstone, in poorly defined beds that range in thickness from a few tens of centimeters to as much as several meters; conglomerate is predominantly poorly to moderately sorted and contains rounded, predominantly andesitic and mafic volcanic-rock clasts in sandy matrix. Conglomerate grades 
upwards into sandstone and pebbly sandstone, locally with carbonate concretions, and subordinate red sandstone and siltstone (Mitchell and Blissett, 2001).

In Puerto Rico, the Maastrichtian to Santonian Achiote Conglomerate, exposed in central part of island, is as much as $1,800 \mathrm{~m}$ of massive, red volcanic-rock conglomerate of well-rounded clasts of red and green andesite and chert, in red mudstone matrix, as well as interbedded green tuffaceous conglomeratic sandstone (Mattson, 1967). The Cariblanco Formation, also in central Puerto Rico, has a maximum estimated thickness of 1,000 $\mathrm{m}$ of volcaniclastic conglomerate, sandstone, and siltstone; it is divided into four members, a flow member at its base, a massive tuff member, and two limestone members in its upper part. The conglomerate is dominantly composed of hornblende dacite, welded ash-flow tuff, amygdaloidal plagioclase-pyroxene biotite andesite, and subordinate sandstone, siltstone, and limestone clasts (Krushensky and Schellekens, 1999). The Achiote Conglomerate is the approximate stratigraphic equivalent of massive conglomerate of the Cariblanco Formation.

In the Virgin Islands, the somewhat-equivalent Louisenhoj Formation is mapped as the intermediatecomposition and silicic volcanic rocks subunit (Kip) here

$\mathrm{Ku} \quad$ Undifferentiated clastic rocks (Upper Cretaceous, Maastrichtian to Campanian) —Widely exposed throughout the Greater Antilles and Virgin Islands, these clastic rocks range from shale to conglomerate.

Exposed in a very limited area in central Cuba, the Camajan Formation of Pushcharovsky and others (1988) is breccia, calcarenite, and calcilutite associated with the Carmita Formation (mapped as the limestone and minor calcarenite subunit [Kelc] here). Much more widely exposed in eastern Cuba is the Picota Formation (or the La Picota Formation), which consists of polymictic conglomerate containing interbeds of poorly sorted polymictic sandstone and breccia-conglomerate (Pushcharovsky and others, 1988). Pardo (2009) considered the Micara Formation (described in the mixed volcanic and clastic rocks subunit [TKvc] description here) to be a member of the Picota Formation and reported only Cretaceous fossils from the Micara Formation.

In the eastern and southern parts of Dominican Republic, scattered outcrops of Upper Cretaceous conglomerate have been reported (Toloczyki and others, 1991).

Several units in Jamaica are included here. In western Jamaica, several defined units are exposed in the Lucca (or Hanover) and Saint James (or Sunderland) Inliers of Hastie (2007). The Hanover Formation (or Hanover Shale), exposed in the Lucca Inlier, is divided into lower and upper units (Arden, 1975). Lower unit is calcareous mudstone containing thin interbeds of limestone and calcareous sandstone; the Clifton Limestone (mapped as the limestone and limestone conglomerate subunit [KIc] here) is found at top of lower unit. Upper unit is sandy and contains conglomeratic and shaly lenses. Arden (1975) indicated that the Hanover Shale was of Campanian age, whereas McFarlane and others (1984) considered it to be Santonian to Coniacian in age. The Green Island, Jerusalem Mountain, Masemure, and Morland Formations, which all lie within the Lucca and Westmoreland Inliers of western Jamaica, may be encompassed by the Hanover Shale of Arden (1975). The Newman's Hall Formation, gray shale that contains calcareous concretions, and the Sunderland Formation, brown-weathering shale and sandstone, are found in the Saint James Inlier (Jiang, 1993). Jiang (1993) indicated that the Newman's Hall and Sunderland Formations are of Campanian age on the basis of nannofossils, whereas McFarlane and others (1984) considered them Santonian to Coniacian in age. In eastern Jamaica, the Ginger House Member of the Bellevue Formation is purple to gray, polymictic conglomerate that has sandy tuffaceous matrix along with clasts of porphyritic andesite and bright-green, chloritized pelitic rocks (Hastie, 2007). Also in eastern Jamaica, the Bowden Pen Member of the Blue Mountain Formation is a coarse-grained "slump" conglomerate (McFarlane and others, 1984; Hastie, 2007). In northcentral Jamaica, the Cascade Formation of McFarlane and others (1984) is exposed in a fault block in Saint Anne's Inlier. The Shepard's Hall Formation, consisting of conglomerate and tuff, is not dated but is tentatively considered Campanian by Arden (1975). The Saint Anne's Great River Formation (called the Diozoptyxis Shale by McFarlane and others, 1984) was described by Mitchell and others (2011) as $48 \mathrm{~m}$ of dark-gray, silty shale that has common shallow-water fossils and no obvious marker beds; however, because upper part of formation is terminated by a fault, its true thickness is not known (Mitchell and others, 2011). The Veniella Shale was described by Chubb (1955) as about $750 \mathrm{~m}$ of largely nonfossiliferous shale and conglomerate, though uppermost about $45 \mathrm{~m}$ is richly fossiliferous, purple, brown, and gray shale and siltstone that contains indurated sandy beds; some shale is nodular or concretionary. The Windsor Shale, exposed in Saint Anne's Inlier on north-central coast of Jamaica, is Campanian, according to Arden (1975).

In northeastern Puerto Rico, near San Juan, the Monacillo Formation consists of tuffaceous clastic rocks that range from conglomerate to mudstone and locally contains a limestone member, the Trujillo Alto Limestone (Pease, 1968).

Locally, divided into subunits Kvss and Kso 
Kvss Volcaniclastic sandstone and mudstone - In Holguin area of southern Cuba, the La Jiquima Formation was described by Pardo (2009) as 300 m of fine- to medium-bedded, well-sorted, fine- to mediumgrained, brownish-gray to creamy-brown sandstone; commonly contains carbonized plant fragments.

In eastern Puerto Rico, the Frailes Formation has thin, calcareous, foraminiferal mudstone beds which are most abundant near its base and also in the Leprocomio Mudstone Member at its top; the thick, middle part is interbedded grayish-green, andesitic to dacitic volcanic-clast sandstone, pebbly volcanic-clast sandstone, fine-grained volcanic-rock breccia, fine- to medium-grained brecciaconglomerate, and less abundant volcanic-clast mudstones; in eastern exposures, two units of pillowbasalt flows are included (Seiders, 1971).

Over much of Saint Croix in U.S. Virgin Islands, a series of Maastrichtian to Campanian volcaniclastic sandstone units are exposed. One of the oldest, the Allandale Formation, which is only exposed on western Saint Croix, is about $600 \mathrm{~m}$ of most commonly green, tuffaceous sandstone and lesser mudstone, volcanic-breccia, lapilli tuff, flows, and fragmental limestone (Whetten, 1966); volcanic-rock debris is primarily pyroclastic andesite and dacite and minor epiclastic keratophyre and spilite fragments. Of equivalent age, the Caledonia Formation consists of about 30 percent sandstone and 60 to 70 percent mudstone composed chiefly of keratophyre and spilite debris; beds are typically graded from sandstone to mudstone, are 7 to $8 \mathrm{~cm}$ thick, and have sharp, distinct lower contacts. Locally, chert beds are present between the mudstone and the overlying sandstone beds (Whetten, 1966). The formation is at least 2,700 $\mathrm{m}$ thick and may be as much as 5,400 m thick. The East End Member of the Caledonia Formation, exposed in eastern Saint Croix, is composed of tuffaceous sandstone and volcanic-breccia, both of which become coarser eastward, and is about $275 \mathrm{~m}$ thick (Whetten, 1966). The Cane Valley Formation, which overlies the Allandale Formation, is divided into three members, the lower Hope Member and the upper Springfield Member, both largely mudstone, and the middle Robe Hill Member, which is largely tuffaceous mudstone (Whetten, 1966). Overlying all these formations on Saint Croix is the Judith Fancy Formation, composed of tuffaceous rocks about 4,570 m thick; present over a wide area of western and central Saint Croix, rocks of the formation are of variable composition. On western part of island, formation ranges from fine- to coarse-grained tuffaceous sandstone in the west, breccia and lapilli tuff in the north-central part, and tuff and lapilli tuff in the east. On eastern part of island, the Judith Fancy Formation is characterized by tuffaceous sandstone, lapilli tuff, and mudstone, as well as a few thin beds of fossiliferous, fragmental limestone interbedded with tuffaceous rocks (Whetten, 1966)

In northern Cuba, the Via Blanca Formation is as much as several hundred meters of reddishgreen shale, graywacke siltstone, sandstone, and sparse interbeds of white marl. Conglomeratic olistostrome is common and consists of two types, (1) those consisting mostly of igneous-rock material, and (2) those consisting of carbonate-rock fragments, of which high percentage of limestone fragments contain rudists that are probably derived from the underlying San Juan y Martinez Formation (mapped as the clastic rocks and reef limestone unit [Kcls] here). Formation was deposited in shallow- to relatively deep-water conditions; source of material appears to have been in the south-southwest (Pardo, 2009).

In southern Haiti, Vila and others (1985) described calcareous olistostrome deposits within tuffaceous matrix; deposits are rich in basaltic debris but also contain variety of lithologies that include dark chert, radiolarian chert, siliceous and sandy limestone, and diabase.

In Dominican Republic, unit is probably partly equivalent to the flysch unit (TKfs)

Kcls Clastic rocks and reef limestone (Upper Cretaceous, Maastrichtian to Campanian) —Predominantly exposed in central Cuba, unit consists of variety of clastic sedimentary rocks that are always associated with limestone and marl.

In central Cuba, the Duran Formation is about $100 \mathrm{~m}$ of conglomerate, sandstone, volcaniclastic sandstone, and siltstone that contains reef-limestone beds (Pushcharovsky and others, 1988; Pardo, 2009); Pardo (2009) considered it as equivalent to the Jimaguayu Formation (mapped as the limestone and limestone conglomerate subunit [Klc] here). Exposed to the north of the Duran Formation, Pushcharovsky and others (1988) mapped a mixed unit consisting of the Guanaja, Esperanza II, San Pedro, Cantabira, and Isabel Formations, describing them as conglomerate, sandstone, siltstone, marl, limestone, tuff, and vitroclastic rocks. Found in linear belt in northern Cuba, the San Juan y Martinez Formation is described by Pardo (2009) as a minimum of $325 \mathrm{~m}$ of sandstone, siltstone, conglomerate, shale, marly limestone, and masses of rudist limestone. Rapid horizontal changes of lithology are typical for formation; very few beds extend for long distances. The most characteristic and dominant lithology is bioclastic limestone that contains an abundant rudist fauna; rudists are grouped in biostromes, or pseudo-reefs, that show animal shells in upright life position; corals, algae, oysters, bryozoans, and other unidentified organisms also are present. The limestone beds are lenticular and transition to clastic rocks, 
mainly conglomerate lenses that contain boulders as much as several tens of centimeters in diameter; dominant conglomerate clasts are andesite, trachyte, basalt, and tuff; minor quartz-rich sandstone, quartz, and chert clasts are also present. Base of the formation has never been observed. Exposed along south coast of Cuba, the Bruja Oriental Formation of Pushcharovsky and others (1988) was described as sandstone, tuffaceous siltstone, sandy limestone, and conglomerate; Pardo (2009) noted that unit does not seem to have any relation to the Bruja Formation of central Cuba and that he was not aware of the origin of the unit's name nor the basis for its dating.

In southern Dominican Republic, Toloczyki and others (1991) mapped two units, (1) a sandstone, marl, and limestone unit, and (2) a marl and calcarenite unit.

In Puerto Rico, the La Muda Formation was originally considered the La Muda Limestone Member of the Frailes Formation (mapped as the volcaniclastic sandstone and mudstone subunit [Kvss] here); Pease (1968) mapped it as a distinct formation that he defined as being mostly wellbedded arkosic sandstone and siltstone containing lenticular, massive limestone beds. Pease (1968) also described interbedded pebble- to cobble-conglomerate primarily composed of volcanic clasts but locally having "almost exclusively limestone" clasts. Exposed in extreme southwestern Puerto Rico, the Melones Limestone was defined by Mattson (1960) as lower, massive or thick-bedded, dark, argillaceous, lenticular limestone or thin, fossiliferous, medium-bedded mudstone that grades upward into calcareous mudstone and, higher yet, into banded tuff or volcanic-clast wacke, conglomeratic tuff or wacke, calcilutite, and more argillaceous limestone. Also exposed in extreme southwestern Puerto Rico, the Parguera Limestone has lower unit of mostly calcarenite that locally contains volcanic-lithic clasts, mudstone, and massive bioclastic limestone; lower unit also locally includes conglomerate that contains clasts of volcanic rocks, chert, serpentinite, and amphibolite (Volckmann, 1984); upper unit is coarse-grained bioclastic limestone and lesser volcaniclastic conglomerate; the Parguera Limestone lies stratigraphically below the Melones Limestone and may extend into latest Santonian stage

Klcv Mixed clastic, carbonate, and volcanic rocks (Upper Cretaceous, Campanian to Coniacian)—Exposed primarily in Cuba but also in Jamaica.

In Cuba, in Camagüey region, the Contramaestre and Vidot Formations of Pushcharovsky and others (1988) are similar volcaniclastic units that contain tuffaceous sandstone, conglomerate, felsic to intermediate-composition tuff, siltstone, argillite, limestone, andesite, marl, and breccia; however, Pushcharovsky and others (1988) separated the volcanic-rock-rich part of the Contramaestre Formation as a distinct unit, which we have included here in the intermediate and felsic volcanic rocks subunit (Kfv). In the southern part of the same general area, the Yaquimo Formation consists of volcaniclastic rocks, marl, limestone, sandstone, tuffite, siltstone, and tephra (Pushcharovsky and others, 1988). In Santo Domingo-Santa Clara region of central Cuba, Pushcharovsky and others (1988) mapped another mixed unit, made up of the Cotorro, Salvador, Maguey, Hilario, Palmarito, Minerva, and Felipe Formations, that represents nearly 1,000 m of limestone, marl, sandstone, conglomerate, tuff, clastic rocks, and intermediate-composition volcanic rocks.

In northeast Jamaica, the Cross Pass Shale of the Blue Mountain Formation includes shale, as well as tuff and conglomerate

Kue Older undifferentiated clastic rocks (Upper Cretaceous, Santonian to Cenomanian) —Present in Cuba, Jamaica, and Puerto Rico, this is a lithologically diverse clastic unit.

In northwestern Cuba, the Quinones or Felicidad Formation of Pushcharovsky and others (1988) is about $600 \mathrm{~m}$ of interbedded sandy limestone, siltstone, shale, and chert; percentage of shale and chert increases toward upper part of unit; however, sandstone and breccia are present at top. The limestone has abundant planktonic microorganisms, as well as terrigenous and pyroclastic material (Pardo, 2009).

In western Jamaica, unit includes several defined units exposed in Lucca (or Hanover) and Saint James (or Sunderland) Inliers of Hastie (2007). Conglomerate of the John's Hall Formation is found in both Lucca and Saint James Inliers (Jiang, 1993); Jiang (1993) placed the John's Hall Formation stratigraphically below the Sunderland Formation of late early Campanian age, which suggests that it could be as young as Campanian, whereas McFarlane and others (1984) considered it Santonian to Coniacian in age. Exposed in the Central Inlier, the Peter's Hill Formation consists of conglomerate overlain by rudist-bearing limestone that yielded a late Santonian fossil age for unit (Hastie, 2007).

In eastern Puerto Rico, the Barrazas Formation is as much as $1,100 \mathrm{~m}$ of volcanic-clast sandstone and lesser volcaniclastic breccia and calcareous mudstone (Seiders, 1971). In same area, the Canovanas Formation is about $450 \mathrm{~m}$ of calcareous mudstone and calcareous, volcanic-clast sandstone (Seiders, 1971). West of the Barrazas Formation exposures, the Camarones Formation is about 950 $\mathrm{m}$ of tuffaceous siltstone, which is locally carbonaceous, interbedded with tuffaceous sandstone, minor volcanic-clast conglomerate, and local lava flows (Krushensky and Schellekens, 1999). Stratigraphically 
equivalent to the Camarones Formation is the Rio de la Plata Sandstone, consisting of greenish-gray, thin-bedded, tuffaceous sandstone that resembles greenstone and is about $300 \mathrm{~m}$ thick in its maximum exposure (Pease, 1968); conglomerate and lava flow members and a limestone lens are present in unit

Tutu Formation (Cretaceous, Santonian to Albian) - Mixed volcaniclastic sedimentary rocks and their metamorphosed equivalents, in Virgin Islands. Roughly 3,000 m thick: unit is about 1,800 m thick in U.S. Virgin Islands (Donnelly, 1966), and additional about 1,100 $\mathrm{m}$ is present in British Virgin Islands (Helsley, 1960). As mapped in British Virgin Islands by Helsley (1960) and in U.S. Virgin Islands by Donnelly (1966) and Rankin (2002), unit consists of volcanic-clast wacke, shale, conglomerate, calcareous siltstone, sparse limestone, and rare basalt and andesite, or their metamorphosed equivalents (Rankin, 2002). Rankin (2002) divided unit into two members on Saint John Island that have yet to be extended to other islands. Helsley (1960) described unit as

"thin bedded fine-grained tuffaceous wacke interbedded with coarser grained materials of about the same character. Graded bedding is present in the finer units but is reported to be absent from the coarser units. Considerable variation is present in both size of material, varying from silt to cobbles, and in thickness of individual beds, varying from less than an inch in the finer wackes to more than thirty feet in conglomeratic units. Numerous fragments of limestone and of underlying beds are incorporated in the finer sediments suggesting the presence of currents capable of carrying large fragments of material originally formed or deposited nearer to the shore. Slump structures are present showing transport to the north and indicating deposition on a northward sloping surface".

In British Virgin Islands, the Tutu Formation surrounds the Coki Point megabreccia, which Helsley (1960) and Donnelly (1966) described as consisting of large (some more than $30 \mathrm{~m} \mathrm{long}$ ) blocks of shallow-water limestone mixed with andesitic volcanic rocks and tuffaceous wacke of the Tutu Formation at its base, thought to represent a massive slump deposit. Near top of the Tutu Formation, the Congo Cay limestone is coarsely crystalline limestone that contains gastropod molds (Helsley, 1960). As shown here, the Tutu Formation includes the Picara Member, which consists of porphyritic meta-andesite, on Saint John (Rankin, 2002)

Ksv Older mixed clastic, carbonate, and volcanic rocks (Cretaceous, Cenomanian to Albian) - Wide variety of sedimentary and volcanic rocks, though sedimentary rocks are dominant, exposed in Cuba and Puerto Rico.

In south-central Cuba, Pushcharovsky and others (1988) mapped a Provincial Formation, described as volcaniclastic rocks; Pardo (2009) indicated that the Provincial Formation was a combination of three formations, the Gomez, Casanova, and Cristobal Formations. Lowest is the Cristobal Formation, about $150 \mathrm{~m}$ of interbedded thin- to medium-bedded limestone, thin-bedded shale, and calcarenite; limestone is oolitic, dense, fragmental, and contains radiolaria. The calcarenite can be coarse, and it contains mollusk remains and reworked oolites of Late Jurassic age (Pardo, 2009). The Casanova Formation was described by Pardo (2009) as about $180 \mathrm{~m}$ of argillaceous, dense to fragmental, yellowishbrown limestone interbedded with thinly bedded shale and containing in the middle of the section a 45-m-thick, dark-gray porphyry flow; upper part of formation contains tuffaceous sandstone and conglomerate, as well as a rudist reef. The Gomez Formation is correlative with the Casanova Formation; however, Pardo (2009) considered it distinctive because it is detrital and not associated with volcanism, saying that it is about $150 \mathrm{~m}$

"of black to dark-brown, thin-bedded, sometimes nodular, shaly limestone with interbed-

ded dark-gray shales toward the base. Toward the top, the limestones are lighter colored and occasionally fragmental and interbedded with yellowish marls. Some calcareous, fine-grained sandstones are present, containing basic plagioclase, green hornblende, apatite, chlorite, volcanic grains, and bands of heavy minerals" (Pardo, 2009).

Also included here are the La Trampa, Yeguas, and Turquino Formations of Pushcharovsky and others (1988). In northernmost Cuba, the La Trampa Formation consists of clastic (including volcaniclastic) rocks, calcareous tuffaceous rocks, and dacite and andesite flows. Exposed west of Camagüey, the Yeguas Formation consists of siltstone, tuffaceous sandstone, tuff, and limestone. In a very limited area along the south coast of Cuba, the Turquino Formation was described by Pushcharovsky and others (1988) as argillite, calcareous siltstone, tuff, conglomerate, and agglomerate; Pardo (2009) indicated that formation was mapped by Pushcharovsky and others (1988) as being near the type area of what he called the Palma Mocha Formation, which he described as about $200 \mathrm{~m}$ of thin- to medium-bedded, black to dark-gray limestone containing local interbeds of crystal-lithic tuff. 
In Puerto Rico, Krushensky and Schellekens (1999) described three formations: In south-central Puerto Rico, the Robles Formation is chiefly volcaniclastic sandstone and siltstone and subordinate pillowed basaltic andesite flows and minor limestone, conglomerate, and breccia; locally, it contains calcarenite at its base; formation is at least 1,200 m thick. Rocks that are lithologically and stratigraphically equivalent to the Robles Formation are mapped as the Magueyes Formation, described as massive to thin-bedded, fine- to coarse-grained, dark-greenish-gray, tuffaceous sandstone and thin-bedded, very fine grained, dark-gray, tuffaceous siltstone, intercalated with amygdaloidal, pillowed, chiefly basaltic and lesser andesitic flows and flow breccia and, near its top, a thick, unsorted, basaltic hyaloclastite breccia; at its base is the Barrancas Limestone Member (not mapped separately here), which consists of mediumto dark-gray, massive, finely crystalline limestone and includes fossils of middle Albian age; maximum estimated thickness of the Magueyes Formation (including the Barrancas Limestone Member), 1,400 $\mathrm{m}$. Third formation, the Pajaros Tuff, exposed northeast of the Robles and Magueyes Formations, consists of tuff, tuffaceous siltstone, and sandstone; maximum exposed thickness, $580 \mathrm{~m}$

Kmm Martin Mesa Formation and similar formations (Cretaceous, Turonian and lower) —Exposed in a linear belt in northwestern Cuba, the Martin Mesa Formation is massive and stratified biomicritic limestone, calcarenite, quartzose sandstone, slate, and clayey calcareous rocks (Pushcharovsky and others, 1988); Pardo (2009) considered formation as a tectonic complex, consisting of thin-bedded, sometimes massive, gray, micritic limestone associated with medium-grained, brownish-gray sandstone and calcareous slate; locally, sandstone is dominant lithology (Pardo, 2009). Also in northwestern Cuba, unit includes the Buenavista Formation of Pushcharovsky and others (1988), which consists of chert, breccia, limestone, and lenses of argillite and sandstone; later described as the Buenavista Group (Pardo (2009), which includes the Santa Teresa Formation (mapped as the chert unit [Kch] here) and the Carmita Formation (mapped as the limestone and minor calcarenite subunit [Kelc] here); though not mapped here, also includes the Pinalilla Formation (equivalent to unit Kelc here) and the Moreno Formation (equivalent to the clastic rocks and reef limestone unit [Kcls] here)

Ksr Rio Nuevo Formation and similar clastic-rock units (Cretaceous, Cenomanian to Albian) - In northeastern Jamaica, includes limited exposures of the Rio Nuevo and Tiber Formations (McFarlane and others, 1984). The Rio Nuevo Formation is described by Hastie (2007) as siltstone, shale, and carbonate rocks, which have been intensely faulted, and the Tiber Formation as volcanic-clast conglomerate (Hastie, 2007).

In Puerto Rico, includes the Tabonuco Formation, consisting of about 1,000 m of volcaniclastic sandstone, mudstone, minor volcanic breccia, and conglomerate (Krushensky and Schellekens, 1999); primarily exposed in far-eastern Puerto Rico, a small exposure is also mapped in western Puerto Rico

Kch Chert (Cretaceous, Cenomanian to Aptian or lower) - Exposed in a few areas of northern Cuba, includes the Santa Teresa Formation; Pardo (2009) described unit as monotonous succession of thin, 3- to 6-cm-thick, bedded primary chert interbedded with dark, fissile, carbonaceous and sometimes marly or clayey shale, of probable volcanic origin. It is mineralized and stained with manganese oxides. Pardo (2009) described it as a characteristically noncarbonate unit and considered it a deep-water deposit that received strong influx of silica and fine detritus from contemporaneous submarine volcanism to the south. Pardo (2009) made the case that the Cenomanian stage was a time of essentially no volcanic activity in central Cuba and that the stage separates older mafic submarine volcanism from younger, more felsic, arc-volcanic rocks; thus, if the Santa Teresa Formation is related to volcanism, it should not be of Cenomanian age but, instead, either younger or older; in view of its relation with the underlying Constancia and Ronda Formations, and also taking into account that its lithology suggests an association with submarine volcanism and not arc volcanism, Pardo (2009) suggested it is more likely upper Aptian through Albian and not younger than lower Cenomanian.

In eastern Jamaica, the Mount Charles Formation of the Above Rocks Inlier consists of metamorphosed conglomerate, banded chert, and mudstone along with intercalated andesitic tuff and flows, which dip to west (Hastie, 2007).

On the southernmost part of Saint John in U.S. Virgin Islands, Rankin (2002) mapped a very small exposure of light-blue-gray to dark-gray, bedded radiolarian chert of the Water Island Formation (see also map units Kwi, Kevm, and Kkp); Rankin (2002) also implied presence of other areas of chert where radiolarians were not visible

Kwi Water Island Formation, volcanic-clast wacke (Lower Cretaceous) - In U.S. and British Virgin Islands, consists of volcanic wacke of subrounded to angular clasts of keratophyre, basalt, and trondhjemite, in a matrix that is probably comminuted keratophyre but includes xenocrysts of quartz and plagioclase (Rankin, 2002); clasts are poorly sorted and may be more than $1 \mathrm{~m}$ across; bedding generally is poorly defined, but graded bedding is present but rare; pumiceous keratophyre clasts are rare except where 
submarine pumice flows may be present; trondhjemite clasts as large as boulder size (likely from the trondhjemite and keratophyre unit [Kmq] here) are found locally (Rankin, 2002)

Kpf Polier Formation (Lower Cretaceous, Albian to Valanginian) _ Exposed in northern Cuba, Pardo (2009) described formation as thin-bedded micritic limestone interbedded with sandstone and shale as much as 200 to $300 \mathrm{~m}$ thick and decreasing to less than $30 \mathrm{~m}$ southward; lower part of formation is thin-bedded, gray, micritic limestone interbedded with claystone and sandstone. Calcareous-cemented sandstone is gray to dark gray, hard, and fine grained, and generally thin bedded but, locally, has beds as much as $1 \mathrm{~m}$ thick. Beds have organic and inorganic markings at their base, and they have graded bedding and horizontal and cross-laminations; clasts are dominantly poorly rounded quartz and subordinate plagioclase and muscovite; Pardo (2009) considered sandstone to be a turbidite; Pushcharovsky and others (1988) reported bituminous limestone and quartzose sandstone and argillite

\section{CRETACEOUS TO JURASSIC SEDIMENTARY ROCKS}

KJs Limestone and shale (Lower Cretaceous to Upper Jurassic) - Widely exposed in northern Cuba are several formations of limestone, chert, and clastic sedimentary rocks, including the Artemisa, Francisco, and Guasasa Formations of limestone and chert, the Esperanza Formation of bituminous limestone, quartz-rich sandstone, and argillite, and the Veloz and Fidencia Formations of limestone, calcarenite, and interbedded argillite and chert (Pushcharovsky and others, 1988), as well as unnamed units. The Guasasa Formation as mapped here includes its El Americano, Tumbadero, Tumbitas, and Infierno Members, as well as the undivided Guasasa Formation

\section{JURASSIC SEDIMENTARY ROCKS}

Jlc Limestone and dolostone (Upper Jurassic) — Exposed in northwestern and central Cuba. Northwesternmost exposure is represented by the lowest San Vicente Member of the Guasasa Formation, consisting of massive limestone, calcarenite, calcirudite, and micrite, locally dolomitized (Pushcharovsky and others, 1988); Pushcharovsky and others (1988) mapped three distinct map units as the Guasasa Formation (two of which are mapped as the limestone and shale unit [KJs] here). Pardo (2009) described the Guasasa Formation as 300 to $800 \mathrm{~m}$ of bedded to massive, medium-gray to black, bituminous, locally dolomitized limestone that contains chert nodules in its lower part and chert beds in its upper part; Pardo (2009) reported that, in some sections, a sedimentary breccia exists at their base that consists mostly of fragments of the Guasasa Formation but also contains fragments of the underlying Jagua Formation. Also mapped here is the Jagua Formation, which underlies the Guasasa Formation and is exposed in a thin, linear belt in northwestern Cuba (Pushcharovsky and others, 1988). Similar to the Guasasa Formation, the Jagua Formation is 30 to $160 \mathrm{~m}$ of dense, black, bituminous, medium-bedded limestone that contains thick beds of oyster coquina and purple-black shale that has limestone concretions containing a rich fauna of ammonites, fish, and reptile bones (Pardo, 2009). Also included in unit in north-central Cuba, in a linear belt parallel to the coast, is a group of formations mapped by Pushcharovsky and others (1988) as the Trocha, Meneses, and Colorado Formations. This mixed group consists of locally dolomitized, stratified limestone, biomicrite, calcilutite, and calcarenite

\section{IGNEOUS ROCKS}

\section{YOUNG VOLCANIC ROCKS}

Qvm Alkali basalt (Quaternary) — In northern Haiti, consists of nepheline basalt; in east-central Dominican Republic, consists of "alkaline basalt" (Toloczyki and others, 1991). In Haiti, nepheline basalt of the Morne La Vigie and of the eastern part of Chaîne des Matheux is accompanied by ash and scoria (Vila and others, 1985). The 200-m-high scoria cone of Morne La Vigie features fresh deposits of scoria, ash, and tuff and has numerous associated cracked bombs; its crater is $250 \mathrm{~m}$ in diameter (Butterlin, 1960, cited in Vila and others, 1985; Wadge and Wooden, 1982). Wadge and Wooden (1982) described five centers of Quaternary volcanism on the island of Hispaniola: in Haiti, they consist of nepheline basalt; in Dominican Republic, alkali olivine basalt and basanite. In Dominican Republic, flows can be as much as $10 \mathrm{~km}$ long, originating from several vents marked by small cinder cones (Wadge and Wooden, 1982). Wadge and Wooden (1982) reported 1.8 $\pm 0.9 \mathrm{Ma} \mathrm{K} / \mathrm{Ar}$ age (sample H2, table 2) on nephelinite from the Thomazeau field in eastern Haiti and 1.1 $\pm 0.5 \mathrm{Ma} \mathrm{K} / \mathrm{Ar}$ age (sample DR6, table 2) on basanite from the San Juan volcanic field in Dominican Republic

QTv Dos Hermanos and Valle Nuevo volcanic fields (Quaternary, Pleistocene and Tertiary, Pliocene)-In Cordillera Central of Dominican Republic, trachyandesite and latite (Toloczyki and others, 1991). In 
Dos Hermanos volcanic field, consists of numerous domes, flows, and dikes; in Valle Nuevo field, consists of more variable compositions that include rhyolite, andesite, trachyandesite, and phlogopitebearing basalt (Wadge and Wooden, 1982)

\section{TERTIARY VOLCANIC AND HYPABYSSAL ROCKS}

Hypabyssal dikes and intrusions (Tertiary) - In Cuba and Puerto Rico, includes hypabyssal rhyolite and syenite, porphyritic rhyodacite and dacite dikes and hypabyssal intrusions (Pushcharovsky and others, 1988; Krushensky and Schellekens, 1999). In Cuba, also includes Eocene hypabyssal diabase (Pushcharovsky and others, 1988). In British Virgin Islands, includes porphyritic dikes (Helsley, 1960). On Saint John in U.S. Virgin Islands, includes Tertiary(?) mafic dikes (Rankin, 2002); also includes the Red Hook tonalite porphyry, which is characterized by large bipyramidal quartz and barrel-shaped biotite phenocrysts, in aphanitic to fine-grained and locally spherulitic groundmass; phenocrysts may constitute as much as 45 percent of rock that consists of quartz, plagioclase, biotite, less commonly hornblende, and prominent apatite (Rankin, 2002). Where age is reasonably well controlled, unit is thought of as Eocene; however, in many cases, age of Tertiary is as precise as can be defined

Tv Intermediate and mafic flows and tuff (Tertiary, Miocene to Eocene) - In southern Cuba, includes basalt of Oligocene age (Pushcharovsky and others, 1988).

In Dominican Republic (in Sierra de Neiba and Sierra de Baoruco), includes subaerial and submarine basalt, tuff, and agglomerate (Toloczyki and others, 1991).

In Haiti, includes titaniferous augite-bearing basalt and pillow-basalt flows of the Massif du NordOuest (Northwest Mountains) and in the region d'Ennery (at the east end of exposures at Massif du Nord-Ouest), as well as, on southern peninsula, flows interbedded within sedimentary units of Eocene or younger age. Pillow-basalt flows are exposed mostly in d'Ennery region, interstratified with middle Eocene or younger limestone.

In Jamaica, includes the Miocene Low Layton Lavas (McFarlane and others, 1984), which resulted from submarine-fissure eruption that produced modest volume of alkaline basalt at Low Layton, on north coast of Jamaica $\left(18^{\circ} 12.99^{\prime} \mathrm{N} ., 7^{\circ} 35.77^{\prime} \mathrm{W}\right.$.). The eruption, which occurred in no more than a few hundred meters of water, produced a series of hyaloclastite, pillow-basalt breccia and flows, massive flows, and dikes that have east-northeast-trending, en echelon structural grain; volcano lies on strike with Dunavale Fault Zone, one of island's major east-west-striking strike-slip fault zones (Wadge, 1982). Exposed in eastern Jamaica are three additional volcanic-rock formations of Eocene age, the Halberstadt Volcanics, the Nutfield Volcanics, and the Newcastle Volcanics (McFarlane and others, 1984), which are associated with the Wagwater Formation (mapped as the volcanic clast-bearing rocks unit [Tpcr] here). The Newcastle Volcanics, the most extensive of the three volcanic-rock formations, is porphyritic andesite, dacite, and quartz keratophyre flows and their sedimentary derivatives (Roobol, 1972, cited in Mann and Burke, 1990); "the Newcastle Volcanics are most abundant in the Dry River Member of the Wagwater Formation, but are also found in the Ginger River and Pencar River Members of the Wagwater Formation and the Roadside Member of the Richmond Formation" (Mann and Burke, 1990). The basalt pillow lavas of the Halberstadt Volcanics, 200 to $300 \mathrm{~m}$ thick, are contained within the Pencar River Member. The Nutfield Volcanics are a thin sheet of basaltic pillow-lava flows conformably overlain by a dacite flow (Roobol, 1972, cited in Mann and Burke, 1990).

In Puerto Rico, the Jobos Formation consists of estimated 1,700 m of volcanic-rock breccia and some volcanic-rock conglomerate and sandstone, as well as andesite flows (Nelson, 1967; Krushensky and Schellekens, 1999).

In British Virgin Islands, Helsley (1960) reported small areas of Tertiary (middle Eocene?) basalt on Guana, Scrub, and Necker Islands augite-andesite breccia, tuff, and volcanic-lithic sandstone about 6,000 m thick of the undivided Tortola Formation (as roof pendants on Virgin Gorda Island) and its Shark Bay, Hans Lollik, and Sage Mountain Members. (Note that, in U.S. Virgin Islands, the Hans Lollik Member is considered a formation, part of the Virgin Island Group). The Tortola Formation is a sequence of andesitic breccia, tuff, and reworked tuffaceous sedimentary rocks that are well exposed on northern Tortola and on Jost Van Dyke Islands and also are exposed as roof pendants on Virgin Gorda Island. It is deformed, having dips as high as nearly $90^{\circ}$; locally, moderately to intensely contact metamorphosed adjacent to the Narrows pluton (U.S. Virgin Islands name, on Saint John) or Virgin Gorda batholith (British Virgin Islands name; these are the same pluton and are mapped as the granite and granodiorite unit [Tegr] here) (Helsley, 1960; Donnelly, 1966). In addition to volcanic-rock lithologies, several minor limestone and limestonebreccia units are present, which have yielded foraminifera of Eocene age. The Shark Bay Member is 
distinctive because of its characteristic whitish-green color and abundant fragments of dark-green glass fragments; in its upper part, it also includes the Mount Healthy shallow-water limestone lentil (mapped as the limestone containing igneous-rock debris unit [Tec] here). The Shark Bay Member conformably overlies, and interfingers with, the Sage Mountain and Hans Lollik Members. Donnelly (1966) indicated that the Hans Lollik Formation of the Water Island Group is Albian; however, available foraminifera and radiometric dates (Alminas and others, 1994) support an Eocene age, as indicated by Helsley (1960).

In Puerto Rico, also includes the Río Descalabrado Formation, which consists of dacitic tuff and subordinate mudstone and tuffaceous mudstone and has an estimated thickness of greater than $500 \mathrm{~m}$ (Krushensky and Schellekens, 1999).

In southern Cuba, the Caney Formation consists of air-fall tuff, tuffite, calcareous tuff, lapilli tuff, tuffaceous limestone, and interlayers of flows and agglomerate; associated with similar, but slightly older, rocks of the Cobre Formation (mapped as the tuff and breccia unit [Tvep] here); also associated with the Hongolosongo Formation, which consists of yellowish-gray, poorly bedded, dacite to rhyolite lapilli tuff that is commonly interbedded with agglomerate and ignimbrite; unit is of variable thickness, as much as 3,000 $\mathrm{m}$ (Pardo, 2009).

Locally, divided into subunit Tn

Necker Formation (Tertiary, Eocene?) - In British Virgin Islands, light-green to tan, subaerial tuff and breccia; includes welded tuff in lower part of formation, always near Virgin Gorda batholith (mapped as the granite and granodiorite unit [Tegr] here); tuff is fine grained and interbedded with breccia, as well as with tuffaceous volcanic-clast sandstone whose typical development and excellent exposures on Necker Island led to formation's name; unit also crops out on small islands north of Virgin Gorda and on Guana Island and Great Camanoe Island. Exposed on these three island groups, unit varies from group to group.

In first island group, which includes Necker, Prickly Pear, Eustatia, and Moskito Islands, pyroclastic rocks resemble upper part of the Tortola Formation (mapped as the pyroclastic rocks unit [Tvc] here), the major difference being that they are dominantly fine tuff rather than breccia and are much less deformed; maximum dip, about $40^{\circ}$, average being near $20^{\circ}$, compared to the near $90^{\circ}$ of the Tortola Formation (Helsley, 1960); low-grade metamorphism has yielded epidote as the only probable metamorphic mineral. Basal part of the exposed section, $500 \mathrm{~m}$ of subaerial ash, is on Prickly Pear Island; lower $150 \mathrm{~m}$ is light-blue-green to green, very fine-grained tuff that has poorly developed bedding, interbedded with a few moderately well sorted, coarse, green lithic tuff layers. The upper $365 \mathrm{~m}$ is green, coarse, lithic and lithic-lapilli tuff and a few interbedded layers of breccia and vitric(?) fine tuff that dominantly consists of andesitic and felsic fragments.

Second island group includes Seal Dogs (West Seal Dog and East Seal Dog), Cockroach Island, and George Dog. On Cockroach Island and George Dog, all exposures are amphibolite, and virtually no original textures or structures remain, whereas on Seal Dogs, unit is only mildly metamorphosed. On Seal Dogs, unit consists of breccia and lithic-lapilli tuff, much of which shows evidence of reworking as large slump blocks, several more than $3 \mathrm{~m}$ long, of very poorly bedded to massive, fine-grained, thin-bedded tuff layers within the lapilli tuff. As in first island group, alteration has developed epidote minerals throughout section. The presence of fragmentary quartz crystals on Cockroach Island and George Dog, as well as a dioritic fragment on West Seal Dog that is very similar to the fine-grained intrusive rocks on West Dog (mapped as the granite and granodiorite unit [Tegr] here), is the slight evidence available for grouping these rocks with the Necker Formation (Helsley, 1960). Other than this slight evidence, and their location in the islands, these rocks are more closely related to the Tortola Formation (the pyroclastic rocks unit $[\mathrm{Tvc}]$ here) and may actually belong with it on the basis of their degree of metamorphism, which is not otherwise observed in the Necker Formation.

The third group, on Guana and Great Camanoe Islands, consists of

"a wide variety of rock types all of which were deposited subaerially with the possible exception of one thin bedded to laminated very fine grained porcelaneous tuff, which may have been either a subaqueous or a subaerial deposit. The breccia, lapilli tuff and tuff were all weathered shortly after deposition without reworking, except for probable slumping. Some of the breccia units could be mudflow deposits, however. Several flow units were recognized varying from extensive welded tuffs with columnar jointing to flow breccia of very local development. The entire section, including the later porphyritic basalt dikes and sills, has undergone considerable alteration with replacement of the original rocks by quartz, chlorite, calcite, epidote and sericite. Calcite, chlorite, and quartz are found as replacements throughout the section while epidote and sericite are restricted to local units. The sericite is restricted to the welded tuffs, flows and late basaltic intrusive rocks and may in part be related to metamorphism by the 
batholith and/or the basaltic intrusive rocks. At least some of this widespread alteration is later than the basaltic intrusive rocks, which cut the entire section, and thus the alteration is probably associated with late magmatic and hydrothermal activity associated with the intrusion of the batholith rather than with the basaltic intrusive rocks themselves. Some of the alteration probably took place very shortly after deposition particularly in the case of the welded tuffs which are much more altered than the surrounding lithic tuffs" (Helsley, 1960)

Tvep Tuff and breccia (Tertiary, early Eocene and late Paleocene)_Primarily exposed in southern Cuba, consists of volcaniclastic rocks, undifferentiated tuff, tuffite, andesite, basaltic andesite, tuffaceous sandstone, and beds of limestone. Major part of unit consists of rocks variously known as the Cobre Formation (Pushcharovsky and others, 1988), the Cobre Group, or El Cobre Group (Pardo, 2009). According to Pardo (2009), consists of 5,000 to 6,000 $\mathrm{m}$ of dominantly porphyritic andesitic flows, agglomerate, crystal-lithic, vitroclastic, and calcareous tuff, and lenses and beds of bioclastic and tuffaceous limestone. Porphyritic dacite and rhyolite are also present in lesser amounts, rhyolite locally being sulfidebearing. Well-bedded, well-sorted graywacke is present in western exposures. Various lithologies grade into each other laterally and vertically, making it extremely difficult to subdivide unit. Numerous dioritic intrusive bodies cut rocks of the Cobre Formation, causing much contact metamorphism of intruded rocks. Exposed northeast of the Cobre Formation is the Miranda Formation, which consists of about 300 to $350 \mathrm{~m}$ (and as much as $900 \mathrm{~m}$ ) of thin- to medium-bedded, green to greenish-yellow to yellowishwhite and gray to white, porous, vitric, lithic-vitric, and crystal-vitric tuff and lesser conglomerate, breccia, marl, and limestone; small areas of andesite, basaltic andesite, and dacitic andesite are also present. Locally, tuff is zeolitized or bentonitic, or it may be silicified and chloritized. Also locally, poorly sorted conglomeratic breccia (lenses?), as much as $250 \mathrm{~m}$ thick, contains clasts of andesite and aphanitic, white limestone as much as $12 \mathrm{~cm}$ in size; limestone contains late Paleocene to early Eocene faunas (Pardo, 2009).

In southwestern Puerto Rico, unit includes the Jicara Formation, which consists of about 1,000 m of laminated, conchoidal-fracturing tuff composed of pale-green glass shards, quartz, and rare pyroxene and plagioclase (Krushensky and Schellekens, 1999). Found north of this formation is the Yunes Formation, which consists of as much as 3,000 m of quartz-bearing, vitric and crystal-vitric tuff, locally graded volcanic-lithic sandstone, and siltstone; also includes minor volcanic breccia, conglomerate, calcarenite, and flows

Tbt Intermediate to felsic biotite tuff (Tertiary, early Paleocene) - In Puerto Rico, consists of the Los Puertos Formation, an andesitic volcaniclastic breccia as much as $350 \mathrm{~m}$ thick, locally interbedded with quartzbearing dacitic tuff, presence of which distinguishes it from the underlying Cretaceous Coamo Formation (mapped as the andesitic breccia, flows, and tuff subunit [Kvl] here) (Krushensky and Schellekens, 1999)

\section{TERTIARY TO CRETACEOUS VOLCANIC ROCKS}

TKrd Dacite and keratophyre (Tertiary to Late Cretaceous)_Exposed in west-central Puerto Rico is dacite associated with the andesite and basalt flows and tuff subunit (TKmv); locally aphyric and vesicular or amygdaloidal; other exposures are of porphyritic hornblende dacite (Krushensky and Schellekens, 1999). Exposed in the extreme eastern part of Puerto Rico is quartz keratophyre associated with Cretaceous andesite of the intermediate-composition volcanic rocks subunit (Kevi)

TKv Extrusive rocks, flows, tuff, and breccia (Tertiary, Paleocene to Late Cretaceous, Campanian?) Largely restricted to eastern Puerto Rico are the Guaracanal and Naranjito Formations. The Guaracanal Formation is volcanic breccia interlayered with basaltic flows and tuff and, locally, has limestone at its base; maximum estimated thickness, 125 m (Seiders, 1971; Krushensky and Schellekens, 1999). Cox and others (1977) reported K/Ar age of 61.8 $\pm 1.2 \mathrm{Ma}$ (sample 23-8, table 2; age recalculated using constants of Steiger and Jager, 1977) on andesite from the Guaracanal Formation. In the same region but farther west is the Naranjito Formation, which consists of crystal-tuff, tuffaceous breccia and conglomerate, volcanic-lithic sandstone, and, locally, basalt flows; maximum thickness, $450 \mathrm{~m}$ (Krushensky and Schellekens, 1999). The Guaracanal Formation and the (partly correlative) Naranjito Formation are considered early Paleogene(?) to Late Cretaceous(?)

TKrr Rhyodacite and rhyolite (Tertiary, Paleocene to Late Cretaceous) - In central Dominican Republic, consists of rhyodacite and rhyolite that overlies tonalite (mapped as the granitic rocks, granodiorite, and tonalite unit [TKtm] here) (Toloczyki and others, 1991) 


\section{CRETACEOUS VOLCANIC AND HYPABYSSAL ROCKS}

Khk Hypabyssal rocks and keratophyre porphyry (Cretaceous) - Primarily exposed in central Cuba, Pushcharovsky and others (1988) mapped several mafic dikes and small diabase bodies, which vary in composition from gabbro, diabase, andesite, and porphyritic diorite to lamprophyre. On Saint John and on nearby islands in U.S. Virgin Islands, Rankin (2002) described the Careen Hill Intrusive Suite, which consists of variety of keratophyre dikes and plugs that intrude the Water Island Formation (Kwi); dikes and plugs vary from coarsely porphyritic to phenocryst-poor bodies; minor diabase is present

Kvr Volcanic rocks, undivided (Cretaceous) - In Cuba, Haiti, Dominican Republic, Jamaica, and Puerto Rico, consists of undivided volcanic rocks of loosely defined Cretaceous age, which range in composition from rhyolite to basalt. In northern Cuba, Pushcharovsky and others (1988) mapped unit simply defined as Cretaceous basalt. In northeastern part of Haiti, Vila and others (1985) mapped Early Cretaceous calc-alkaline volcanic complexes and Late Cretaceous andesite to rhyolite as single unit. In adjoining Dominican Republic, similar volcanic rocks may be included in the rhyodacite and rhyolite unit (TKrr) and the intermediate-composition volcanic rocks unit (Kevi) mapped here (Toloczyki and others, 1991). In eastern Jamaica, McFarlane and others (1984) mapped andesitic volcanic rocks.

In Puerto Rico, rocks mapped by Krushensky and Schellekens (1999) as their informal formations "A," "B," "C," and "J" consist of more than 5,000 m of nonpillowed flows, volcanic breccia, sandstone, and conglomerate, as well as minor limestone, siltstone, and tuff. In what are apparently roof pendants of nearby plutons, Krushensky and Schellekens (1999) also mapped hornblende hornfels, described as metavolcanic rocks that preserve textures of original flows, volcanic breccia, tuff, and volcanic-lithic sandstone.

Locally, divided into subunits Kvl, Klmv, Kvf, Kfv, Kip, Kvib, Kwt, Kmvm, Kevi, Kevm, Kkp, and Kspf, which have more closely defined ages

Kvl Andesitic breccia, flows, and tuff (Late Cretaceous, Maastrichtian to Santonian) - In Puerto Rico, consists of tuff and volcanic breccia; locally includes pillowed and nonpillowed andesitic flows and lenses and beds of calcarenite, volcanic-lithic sandstone, and conglomerate of the 300-m-thick Coamo Formation, the 2,220-m-thick Manicaboa Formation, the 1,500-m-thick Tetuan Formation, and the 700-m-thick Tortugas Formation (Krushensky and Schellekens, 1999). The Alonso Formation, largely consisting of welded and nonwelded ash-flow tuff, overlies the Tetuan Formation (Krushensky and Schellekens, 1999).

On Isla de Vieques (Vieques Island), Learned and others (1973) mapped Late Cretaceous andesite, tuff, and breccia, intruded by a large quartz dioritic batholith (mapped as the quartz diorite and diorite unit [TKqt] here).

In northern and southern Cuba, also includes small exposures of Late Cretaceous andesite (Pushcharovsky and others, 1988).

In eastern Jamaica, the Border Formation in the Above Rocks Inlier is mainly andesitic tuff, flows, and volcanic bombs; Hastie (2007) indicated that unit was of Late Cretaceous, Campanian, age, likely on the basis of a ${ }^{40} \mathrm{Ar} /{ }^{39} \mathrm{Ar}$ date on altered andesite, whereas McFarlane and others (1984) described it as early Albian to Barremian. The Arthurs Seat Formation of the Central Inlier is a "thick succession of sedimentary and volcanic rocks, including andesite, basaltic andesite, volcaniclastic sandstone and conglomerate, and rare rhyolite" (Mitchell, 2013b); according to Mitchell (2013b), age control is lacking, but he infers a Santonian age

KImv Basalt, pillowed and nonpillowed flows, breccia, and tuff (Late Cretaceous, Maastrichtian to Santonian) - Present in Haiti, Dominican Republic, Jamaica, and Puerto Rico. In Haiti, Vila and others (1985) mapped andesite, basalt, and equivalent tuffaceous rocks of the Massif du Nord (Northern Mountains), as well as basalt and chert, including radiolarian chert, of the southern peninsula and Montagnes Noires. In Massif du Nord, andesitic and basaltic flows and tuff form thick deposits that contain rare siliceous or calcareous interbeds (red or purplish biomicrite of late Campanian to early Maastrichtian age). On the southern peninsula, thick basalt flows and pillow-basalt flows are associated with radiolarian chert and chert of Turonian to Maastrichtian age.

In Dominican Republic, Toloczyki and others (1991) mapped a basic volcaniclastic member of the Tireo Formation, which appears equivalent to the rocks mapped by Vila and others (1985) in the Massif du Nord. In Jamaica, the Bullhead Volcanics or Main Ridge Volcanics of the Central Inlier are largely basalt flows overlain by volcaniclastic conglomerate (Mitchell, 2013b).

In Puerto Rico, multiple formations are mapped as part of unit. Generally, nonpillowed rock units typically are basaltic or basaltic andesite flows, locally containing lenses of limestone and tuffaceous beds; these include the Boqueron Basalt and the El Rayo and Lajas Formations, as well as an unnamed olivine basalt in southwestern Puerto Rico and the Martin Gonzales Lava in northeastern 
Puerto Rico (Krushensky and Schellekens, 1999). Also in Puerto Rico are many pillowed formations, which typically contain, in addition to andesitic pillow flows, interbedded tuffaceous sandstone, and some volcanic-rock breccia and conglomerate. Some of these map units are more tuff or breccia than flows. Formations include the undivided Avispa and Perchas Formations (where mapped separately, the Perchas Formation is included in the undivided volcanic rocks unit [Kvr] here); the Cotorra Tuff of central Puerto Rico; the Lago Garzas Formation of western and central Puerto Rico; the Concepcion Formation of western Puerto Rico; the Malo Breccia and Mameyes Formation of central Puerto Rico; and the Celada and Lomas Formations and the Santa Olaya Lava of eastern Puerto Rico (Krushensky and Schellekens, 1999)

Kvf Felsic volcanic and hypabyssal rocks (Late Cretaceous, Campanian)_Exposed in a small area of central Cuba are felsic flows and tuff of the Marti Formation, which overlie slightly older pyroclastic deposits of the Guaimaro Formation of Pushcharovsky and others (1988) (mapped as the intermediate and mafic pyroclastic rocks subunit [Kwt] here).

In Dominican Republic, dacite and rhyolite domes of the Tireo Formation are exposed in central Hispaniola (Toloczyki and Raminez, 1991); another more extrusive part of the Tireo Formation is mapped as the basalt, pillowed and nonpillowed flows, breccia, and tuff subunit (KImv) here, and a sedimentary component is mapped as the mixed sedimentary and volcanic rocks unit (Ksvr) here

Kfv Intermediate and felsic volcanic rocks (Cretaceous, Campanian to Coniacian) - In central Cuba, unit is represented by three formations that consist of rhyolite to andesite flows, tuff, and domes; all three formations contain zeolitized tuff. The Bruja Formation (distinct from the Bruja Oriental Formation of the clastic rocks and reef limestone unit [Kcls] mapped here) is andesite, dacite, rhyodacite, tuff, tuffite, sandstone, siltstone, and marl. The Caobilla Formation of felsic to intermediate flows and tuff is locally hydrothermally altered. Also includes the volcanic phase of the Contramaestre Formation, which also includes minor basaltic andesite and basalt (Pushcharovsky and others, 1988). Pardo (2009) disagreed with assignment of these volcanic rocks to the Contramaestre Formation and asserted that they are more correctly part of his (Pardo's) Camujiro Formation (not mapped or described here) ${ }^{3}$

Kip Intermediate and silicic pyroclastic rocks (Late Cretaceous, Turonian to Cenomanian?) — Largely andesitic to dacitic tuff and tuffaceous sedimentary rocks; locally includes basalt, marl, and limestone.

In Cuba, the Orozco Formation of northwestern Cuba and the Seibabo Formation of central Cuba (Pushcharovsky and others, 1988) have very limited exposure and include significant sedimentary rocks.

In northeastern Puerto Rico, the Cambalache Formation, largely of pumiceous volcanic breccia, is distinctive because of as much as $50 \mathrm{~m}$ of vitrophyre at its top (Seiders, 1971). Also, in northeastern Puerto Rico, the Cancel Breccia is as much as 2,000 m of andesitic tuff breccia and flows; the nearby Carraizo Breccia, as much as $1,400 \mathrm{~m}$ thick, is similar, though it also includes subordinate tuffaceous sandstone and siltstone in addition to tuff (Krushensky and Schellekens, 1999). The El Ocho Formation, exposed adjacent to the Cancel Breccia, is also similar, consisting of volcaniclastic breccia and tuff as much as $825 \mathrm{~m}$ thick.

In U.S. Virgin Islands, the Louisenhoj Formation is widely exposed on Saint Thomas and Saint John Islands, as well as on outlying islands north and west of Saint Thomas; possibly slightly older than other formations of this map unit because its age may extend into the Albian. The Louisenhoj Formation is volcanic breccia, tuff, and minor conglomerate and varies in mode of deposition from pyroclastic to epiclastic (Donnelly, 1966). Rankin (2002) locally mapped separate flow units within the Louisenhoj Formation, which are included in the mafic volcanic rocks subunit (Kmvm) here; formation is thickest on western Saint Thomas, where it is nearly $4 \mathrm{~km}$ thick (Donnelly, 1966), and it thins to as little as 500 $m$ on eastern Saint Thomas, according to Rankin (2002). Deposition was clearly more distal in the west; in the east, the formation may have calcareous cement in conglomeratic beds (Rankin, 2002). In the type section on Saint Thomas, formation consists dominantly of coarse, water-laid andesitic tuff beds 2 to $4 \mathrm{~m}$ thick, having "fair" grading and showing evidence of laminar slumping (Donnelly, 1966). Locally, softsediment deformation and broken, finer grained beds are present (Rankin, 2002).

On Salt Island in British Virgin Islands, Helsley (1960) tentatively correlated exposures of metamorphosed andesitic breccia and tuff with the Louisenhoj Formation

Kvib Iberia Formation of Cuba (Cretaceous, Turonian to Albian) - Mapped in southern Cuba; Pushcharovsky and others (1988) described vast majority of formation as volcaniclastic rocks, sandstone, diabase, tuff, limestone, and clastic rocks (their unit "Kul-ib") and a very small fraction being primarily

\footnotetext{
${ }^{3}$ According to Pardo (2009), the Camujiro Formation "consists of approximately 11,500-13,000 $\mathrm{ft}(3,500-4,000 \mathrm{~m})$ of volcanic-derived basal conglomerates, overlain by crystalline tuffs, and basaltic to intermediate lavas. A horizon some $40 \mathrm{ft}(12 \mathrm{~m})$ in thickness consists of lenses of gray crystalline limestones containing rudists and interbedded with tuffs. The limestones contain Tepeyasia corrugata and Ichtyosarcolites sp. The tuffs contain Hedbergella sp. and Ticinella sp. The Camujiro formation is considered to be upper Albian to Turonian in age."
} 
andesite (their unit "Kulv-ib"). Pardo (2009) considered unit to be "wastebasket" because it consists of a large variety of rock types that range in age from Albian to Maastrichtian, in which pyroclastic rocks are 80 percent of the formation, flows and dikes are 15 percent, and conglomerate, sandstone, and limestone are only 5 percent of unit. Pushcharovsky and others (1988) mapped a small outlier of metavolcanic rocks in southernmost Cuba as metamorphosed Iberia Formation (their unit "Kulm-ib")

Kwt Intermediate and mafic pyroclastic rocks (Cretaceous, Cenomanian to Aptian) - Mapped in Cuba; consists of volcaniclastic rocks that range in composition from dacite to basaltic andesite but are largely andesite. In northernmost Cuba, the Chirino Formation is about 1,000 m of predominantly vitric and crystalline tuff and tuffaceous chert, medium- to coarse-grained lithic tuff, andesite flows, graywacke, tuffaceous shale, and argillaceous limestone (Pardo, 2009). In central Cuba, Pushcharovsky and others (1988) described the combined Matagua, Villa Clara, and Cabaiguan Formations as a mixture of mafic to intermediate flows (basalt and basaltic andesite), clastic rocks, breccia, dacitic and andesitic tuff, tuffite, and limestone. The Matagua Formation is considered as Albian to Aptian, whereas the Cabaiguan Formation is Albian. In south-central Cuba, the Guaimaro Formation is described by Pushcharovsky and others (1988) as volcaniclastic rocks, flows, and tuff, andesite, basaltic andesite, basalt, and limestone. As with the Contramaestre Formation above, Pardo (2009) disagreed with assignment of rocks to the Guaimaro Formation here and asserted that they are more correctly part of his (Pardo's) Camujiro Formation. In southern Cuba, Pushcharovsky and others (1988) also mapped the combined Santo Domingo and Bucuey Formations, which consist of tuff, andesite, subordinate agglomerate, thin limestone beds, and rare lenses of conglomerate (Pardo, 2009); Pardo (2009) described combined formations as the Bucuey Formation, which Pushcharovsky and others (1988) divided into the Santo Domingo Formation and the slightly more mafic Teneme Formation (basaltic andesite and basalt); as mapped by Pushcharovsky and others (1988), the Teneme Formation has very limited exposure, northeast of the Santo Domingo Formation

Kmvm Mafic volcanic rocks (Cretaceous, Cenomanian to Barremian) - In northern Cuba, includes the Encrucijada Formation (Pushcharovsky and others, 1988). Largely consisting of basalt flows, the Encrucijada Formation also contains subordinate andesite, as well as sedimentary rocks, dominantly chert but lesser limestone, argillite, and siltstone (Pushcharovsky and others, 1988). On Saint John in U.S. Virgin Islands, unit includes separately mapped flow units of the Louisenhoj Formation of Rankin (2002). As mapped by Rankin (2002), flow units of the Louisenhoj Formation consist of porphyritic basalt, some of which has pillows, and andesite, locally metamorphosed to greenschist facies

Kevi Intermediate-composition volcanic rocks (Early Cretaceous, Albian to Barremian?) —Exposed in Jamaica, Dominican Republic, and Puerto Rico, unit primarily consists of pillowed or brecciated andesitic flows, interbedded with tuff, tuffaceous sandstone, and chert.

In Jamaica, the Devil's Race Course Formation of the Benbow Inlier of McFarlane and others (1984) was elevated to the Devil's Race Course Group status by Brown and Mitchell (2010), who then divided it into nine distinct formations (table 3 ) that have a total thickness exceeding 4,000 m; they thought it was the oldest rock unit in Jamaica.

In eastern Dominican Republic, Toloczyki and others (1991) mapped the widely exposed Peralvillo Formation (sometimes called the Peravilla Formation) that, according to Bowin (1975), is pyroxene andesite and tuff.

In Puerto Rico, several related units are included here. The Daguao Formation (1,000 m thick) and the Figuera Lava (as much as 2,000 $\mathrm{m}$ thick), which are locally interbedded, are exposed in the easternmost part of the island; formations consist of massive andesite flows that are locally pillowed, interlayered with minor volcanic-rock breccia, tuffaceous sandstone, siltstone, tuff, and hyaloclastite breccia. Immediately west of these exposures, the Fajardo Formation (as much as 3,150 $\mathrm{m}$ thick) overlies the Figuera Lava and, according to Krushensky and Schellekens (1999), is basal tuff breccia interbedded with tuff, tuffaceous sandstone, and black cherty siltstone. West of these, but still in eastern Puerto Rico, the Torrecilla Breccia is about 2,000 $\mathrm{m}$ of hyaloclastite breccia and associated flows, subordinate volcanic-lithic sandstone, conglomerate, and siltstone (Krushensky and Schellekens, 1999). On Isla de Culebra (Culebra Island) and most of the surrounding islets, Banks (1962) described the informally named Culebra andesite, more than $700 \mathrm{~m}$ of pillowed and massive andesite flows and interbedded tuff and breccia. Banks (1962) distinguished thick-bedded andesite of the informally named Playa Sardinas breccia member in the lower part of the Culebra andesite

Kevm Basalt and basaltic andesite (Early Cretaceous, Albian and older) - In northeastern Puerto Rico, the Cerro Gorda Lava is as much as 1,100 m of basaltic andesite flows, flow-breccia, and minor tuff and tuff-breccia (Krushensky and Schellekens, 1999). Southeast of formation, the Pitahaya Formation is pillow flows, hyaloclastite breccia, flow-breccia, tuff, and tuff-breccia; locally present are 
Table 3. Formations in the Devil's Race Course Group, Jamaica

[Originally mapped by McFarlane and others (1984) as the Devil's Race Course Formation of the Benbow Inlier; elevated to the Devil's Race Course Group by Brown and Mitchell (2010), who then divided it into nine distinct formations; mapped as the intermediate-composition volcanic rocks subunit (Kevi) here]

\begin{tabular}{|c|c|c|c|}
\hline Unit & Description & Thickness (m) & Age \\
\hline Airy Mount Formation & Volcaniclastic pebble conglomerate and minor sandstone & 350 & $\begin{array}{l}\text { Late Aptian or } \\
\text { early Albian }\end{array}$ \\
\hline Golden Grove Formation & Mafic pillow flows and thin associated volcaniclastic sedimentary rocks & & \\
\hline Burtons Formation & Hard, dark-gray, micritic limestone & 8 & $\begin{array}{l}\text { Late Barremian } \\
\text { to early Aptian }\end{array}$ \\
\hline Ragville Formation & Mafic pillow flows and thin associated volcaniclastic sedimentary rocks & 280 & \\
\hline Benbow Formation & $\begin{array}{l}\text { Very hard, compact, dark-blueish-gray biomicrite, rich in rudists, } \\
\text { gastropods, and corals, and having smaller numbers of chondrodonts } \\
\text { and columnar stromatolites }\end{array}$ & 400 & Barremian \\
\hline Boozy Ridge Formation & Volcaniclastic shale, sandstone, and conglomerate & 510 & \\
\hline Jubilee Formation & $\begin{array}{l}\text { Compact, very hard, dark- to medium-gray limestone interbedded with } \\
\text { mudstone and volcanically derived sandstone and conglomerate }\end{array}$ & 100 to 375 & Hauterivian \\
\hline Redwood Formation & Volcaniclastic pebble conglomerate and sandstone & 510 & \\
\hline Cistern Formation & Basaltic andesite and dacite to rhyolite flows and a few thin tuff beds & 1,600 & Valanginian(?) \\
\hline
\end{tabular}

limestone lenses, which may be metamorphosed to marble and replaced by metasomatic magnetite; tuff facies are locally metamorphosed to phyllite, and most rocks are epidotized or chloritized (Krushensky and Schellekens, 1999). Also included are two units of largely mafic tuff; adjacent to outcrops of the Pitahaya Formation, the Rio Abajo Formation is predominantly massive to medium-bedded and graded, coarse- to fine-grained, medium-gray to brownish-gray, crystal tuff and crystal-lithic tuff, volcaniclastic sandstone, and breccia (Krushensky and Schellekens, 1999). "Subordinate sandstone is thin- to thick-bedded and lithologically similar to the tuff described. Thick-bedded to massive, subrounded to subangular, purple and medium-gray to light yellowish gray-green polymictic volcanic breccia is irregularly interbedded with tuff" (Krushensky and Schellekens, 1999). Breccia clasts include tuff, porphyritic andesite, and abundant clasts of embayed quartz and bipyramidal quartz crystals in tuffaceous matrix. "The tuff facies is metamorphosed to phyllite, or locally to hornblende and mica schist near contacts of major intrusive bodies" (Krushensky and Schellekens, 1999). In central Puerto Rico, Krushensky and Schellekens (1999) mapped the Jayuya Tuff, which they described as "Basaltic crystal-lithic tuff and fine-grained hyaloclastite; subordinate silicified mudstone and volcanic sandstone"; they indicated that locally it is metamorphosed to hornfels, gneiss, and schist.

On Saint John in U.S. Virgin Islands, Rankin (2002) distinguished pillows of amygdaloidal basalt, pillow breccia, and hyaloclastite within the Water Island Formation (mapped as units Kwi and Kkp here).

In central Dominican Republic, basalt and minor tuff, wacke, and chert of the Siete Cabezas Formation was described by Toloczyki and others (1991); however, formation does not appear on their map

Kkp Keratophyre (Early Cretaceous) - The Water Island Formation is well exposed on Saint Thomas and Saint John of U.S. Virgin Islands and on Norman, Peter, Salt, and Cooper Islands of British Virgin Islands. Described by Helsley (1960) as "Predominately light tan to reddish brown keratophyre flows, flow breccia, and tuff interbedded with thin flows of dark green to almost black spilite flows [mapped as the spilitic basalt subunit (Kspf here)] and minor radiolarites." Donnelly (1966) added "a few of the fine-grained tuffaceous beds contain well-preserved Radiolaria of undetermined age"; quartz keratophyre dikes and plugs are present in many parts of unit; both Donnelly (1966) and Rankin (2002) commented that unit is oceanic deposit, Donnelly (1966) suggesting that it was erupted prior to existence of trench or island platform. On Saint Thomas, metamorphic grade increases to the north and east, and spherulites in groundmass of keratophyre are recrystallized and stand out as ovoids, some as large as 4 cm, on weathered surfaces (Rankin (2002). Helsley (1960) pointed out that "in the British Virgin Islands *** the formation has undergone greater metamorphism. The rocks described above are now amphibolite and quartz-mica schist."

In Puerto Rico, Banks (1962) described the informally named Cayo Norte formation as being albite-rich pillow flows, which we tentatively correlate with the Water Island Formation 
Kspf Spilitic basalt (Early Cretaceous) - In U.S. Virgin Islands, spilite flows, which vary greatly in thickness, from a few meters to about $100 \mathrm{~m}$, make up about one-fifth of the thickness of the Water Island Formation. Flows generally are massive and lack columnar joints; though they commonly lack pillow structures, pillows are locally well developed (Donnelly, 1966). On Isla de Culebra in Puerto Rico, Banks (1962) described about 360 m of spilitic lapilli tuff as his informally named Cerro Balcon formation; the lower about $60 \mathrm{~m}$ consists of well-bedded, fine-grained, tan tuff that he (Banks) defined as the Playa Resaca member of informally named Cerro Balcon formation

\section{CRETACEOUS TO JURASSIC VOLCANIC AND HYPABYSSAL ROCKS}

KJb Zurrapandilla Formation and Cajul Basalt (Early Cretaceous to Late Jurassic) - In central Cuba, a linear belt of diabase and basalt, rare siltstone, and limestone constitutes the Zurrapandilla Formation (Pushcharovsky and others, 1988). Pardo (2009) inferred that this unit is his (Pardo's) Cumbre Formation, at least $300 \mathrm{~m}$ of spilitic basalt, diabase, chert, and possible tuff. Pardo (2009) also suggested that it may include a unit traditionally mapped as the Old Volcanics by the Gulf Oil Company, consisting of basalt, porphyritic basalt, and associated sedimentary rocks that overlie the Cumbre Formation.

In western Puerto Rico, Krushensky and Schellekens (1999) mapped two similar units, the Cajul Basalt, consisting of amygdaloidal, pillowed, porphyritic basalt flows on the southwestern part of the island, and the spilitized basalt, associated with ultramafic rocks (mapped as the serpentinite unit [Mzs] here) north of the Cajul Basalt on the west coast of the island

\section{TERTIARY INTRUSIVE ROCKS}

Tegr Granite and granodiorite (Tertiary, Eocene?) - In the Sierra Maestra mountains of southern Cuba, several small granite to granodiorite, and monzonite plutons, which locally, include quartz diorite and tonalite phases, intrude rocks of the Cobre Formation (mapped as the tuff and breccia unit [Tvep] here) (Pushcharovsky and others, 1988). Kysar and others (1998) and Rojas-Agramonte and others (2004, 2006) reported $\mathrm{U} / \mathrm{Pb}$ zircon ages that generally range from $46.9 \pm 0.1$ to $60.2 \pm 2.6 \mathrm{Ma}$ on quartz diorite, tonalite, and trondhjemite. Each sample was from a more mafic phase within bodies mapped as granite, granodiorite, or monzonite. However, some age determinations yielded outlier dates as young as $32 \pm 3$ $\mathrm{Ma}$ (fission-track age on zircon; Rojas-Agramonte and others, 2006) to as old as 310.8 \pm 3.4 Ma (likely inherited zircons or laboratory contamination; Rojas-Agramonte and others, 2006)

Ted Diorite and tonalite (Tertiary, Eocene?) - In the Sierra Maestra mountains of southern Cuba, many small diorite and tonalite plutons intrude rocks of the Cobre Formation (mapped as the tuff and breccia unit [Tvep] here) (Pushcharovsky and others, 1988). Also included in unit are rocks described as plagiogranite, which are associated with tonalite.

In Puerto Rico, Krushensky and Schellekens (1999) described porphyritic hornblende quartz diorite, minor hornblende granodiorite, quartz monzonite, and quartz diorite. Multiple K/Ar age determinations on these rocks range from 34.7 \pm 3.3 to $49.4 \pm 1.3 \mathrm{Ma}$ (Cox and others, 1977; Barabas, 1982); however, many of these age determinations are on hydrothermally altered rocks that are locally pyritized, may be molybdenite bearing, and may include disseminated chalcopyrite in groundmass.

In Virgin Islands, Helsley (1960) described the Virgin Gorda batholith; unit exposed on many islands in British Virgin Islands and on Saint John in U.S. Virgin Islands, where it is locally known as the Narrows pluton. Unit is assumed to underlie much of underwater area between islands; Helsley (1960) conservatively estimated that its area is about $264 \mathrm{~km}^{2}$, including $57 \mathrm{~km}^{2}$ in its western extension, the Narrows pluton; several other major plutons in the batholith include Jost Van Dyke, Peter Island, and Cooper plutons. Helsley (1960) described tonalite as being the most abundant rock type and having considerable textural and compositional variation; however, batholith also includes granodiorite and gabbro, as well as late pegmatite and granite dikes (Helsley, 1960). Multiple U/Pb zircon ages range from $30.64 \pm 0.46 \mathrm{Ma}$ for the Peter Island pluton and $37.62 \pm 0.05$ to $43.56 \pm 0.08 \mathrm{Ma}$ for the plutons on Beef Island (British Virgin Islands) and Virgin Gorda (Schrecengost, 2010). Potassium-argon age determinations $^{4}$ vary somewhat more widely, from $23.7 \pm 0.3$ to $42.80 \pm 2.14 \mathrm{Ma}$ (as well as one outlier age of 60.36 $\pm 3.02 \mathrm{Ma}$ ) for gabbro on Virgin Gorda (Cox and others, 1977; Kesler and Sutter, 1979; Vila and others, 1986; Rankin, 2002).

On Saint John in U.S. Virgin Islands, the multiphase Narrows pluton consists of very-light- to medium-light-gray, medium-grained, nonfoliated biotite-hornblende tonalite and minor gabbro, diorite, granite, and pegmatite (Rankin, 2002); pegmatite is locally copper stained, and pluton as a whole has many xenoliths of stratified country rock, as well as pockets of skarn that contain massive sulfides and

${ }^{4}$ Note that many reported K/Ar age determinations were recalculated using commonly accepted decay constants, as reported by Steiger and Jager (1977). 
have copper staining; pluton produces contact-metamorphic aureole as wide as $2 \mathrm{~km}$ (Rankin, 2002). Reported ${ }^{40} \mathrm{Ar}{ }^{39} \mathrm{Ar}$ plateau ages range from $38.67 \pm 0.22$ to $39.29 \pm 0.22 \mathrm{Ma}$ (Rankin, 2002); Rankin (2002) also reported (and discussed) a 24.3-Ma hornblende K/Ar age (recalculated as $23.7 \pm 0.3 \mathrm{Ma}$, using constants of Steiger and Jager, 1977) on the Narrows pluton that he (Rankin) considered to be "the most puzzling anomaly" and indicated that its meaning was unresolved

Tgn Gabbronorite, norite, and diorite (Tertiary, Eocene) - Exposed primarily as small plutons and dikes, these mafic rocks are exposed in Virgin Islands and in Puerto Rico. In Puerto Rico, several small plutons that intrude mafic volcanic rocks of the andesite and basalt flows and tuff subunit (TKmv) are of inferred late to middle Eocene age.

On Saint John in U.S. Virgin Islands, Rankin (2002) described nearly vertical dikes that range in thickness from a few centimeters to several tens of meters, as well as complex dike swarms, some having internal layering parallel to dike walls; these gabbroic dikes, which are widely scattered across island, typically have chilled margins, and they vary in color index, grain size, and texture. On north half of Saint John, dikes are progressively metamorphosed to amphibolite-facies mineral assemblages; also, toward the north, many dikes have same penetrative cleavage as enclosing stratified rocks and, locally, are broken into segments aligned parallel to cleavage, and yet other dikes postdate cleavage; larger bodies commonly contain epidosite nodules and disseminated epidote (Rankin, 2002). Rankin (2002) thought that, on Saint John, unit includes dikes of more than one age: some are intrusive equivalents of extrusive rocks in enclosing or overlying stratified units; others are part of his (Rankin's) tonalite intrusive event (mapped as the diorite and tonalite unit [Ted] here); and a very few cut lamprophyre dikes of the hypabyssal dikes and intrusions unit (Thb) mapped here.

In British Virgin Islands, Helsley (1960) mapped a small body of banded gabbro on Salt Island that he assigned to the Virgin Gorda batholith. On Virgin Gorda, Helsley (1960) also mapped several northtrending lamprophyre dikes that cut the batholith, which he (Helsley) inferred were of middle Eocene age. Vila and others (1986) and Rankin (2002) reported a 60.36 3.02 Ma whole-rock K/Ar age on gabbro associated with the Virgin Gorda batholith on Virgin Gorda; however, because pluton is interpreted as Eocene and because this is a whole-rock age on gabbro, we discount the anomalously old age

\section{TERTIARY TO CRETACEOUS INTRUSIVE ROCKS}

TKgs Alkali syenite (Tertiary, Paleocene to Late Cretaceous, Maastrichtian?) —In central Puerto Rico, a small body of alkali syenite, which consists of potassium feldspar and augite in a chloritized matrix, intrudes the undivided volcanic rocks unit (Kvr), and it is in close proximity to Cretaceous quartz monzonite of the Morovis stock (Krushensky and Schellekens, 1999). No date is available on this body, but it may be same age as that of nearby Morovis stock, which yielded a 90.2 \pm 1.8 Ma hornblende K/Ar age (Cox and others, 1977; age recalculated using constants of Steiger and Jager, 1977)

TKga Granite and aplite (Tertiary, Paleocene to Late Cretaceous, Maastrichtian?) — In Dominican Republic, Toloczyki and others (1991) mapped a small area of granite enclosed within tonalite of the granitic rocks, granodiorite, and tonalite unit (TKtm); this may be a distinct body or, alternatively, simply a different compositional phase of a larger pluton.

On Isla de Vieques in Puerto Rico, Learned and others (1973) mapped several very small aplite and porphyritic bodies associated with a large batholith

TKgm Granodiorite and quartz monzonite (Tertiary, Paleocene to Late Cretaceous, Maastrichtian?) - Present primarily in Puerto Rico but also in eastern Jamaica and, to a lesser extent, on Saint Thomas in U.S. Virgin Islands.

In Puerto Rico, largest exposure of unit is granodiorite to quartz diorite of the Utuado batholith, in the west-central part of island; generally speaking, it is pale-gray-brown to pale-pink, massive, locally porphyritic, medium- to fine-grained granodiorite and subordinate quartz diorite, quartz monzonite, and diorite; batholith is widely and deeply weathered to very-pale-yellow-brown, sandy saprolite (Krushensky and Schellekens, 1999). Multiple radiometric age determinations that range from about 40 to about $76 \mathrm{Ma}$ were made on rocks in batholith. Older, greater than $70 \mathrm{Ma}$ dates are all on quartz diorite exposed in the southern part of the batholith and may represent a distinct igneous episode. Several radiometric ages determined on rocks in the batholith near the Cala Abajo and Piedra Hueca ore zones yielded middle Eocene ages of about 40 to $42 \mathrm{Ma}$, suggesting that, at least locally, unit may include middle Eocene plutons. Outlying small stocks northeast of the Utuado batholith and in far-eastern Puerto Rico are quartz diorite to granodiorite, none of which has been dated. West of the batholith are two small granodiorite to quartz monzonite plutons, also not dated (Krushensky and Schellekens, 1999). 
Small granodiorite stocks are present in eastern Jamaica (McFarlane and others, 1984). Chubb and Burke (1963) reported a $64 \pm 5 \mathrm{Ma} U / \mathrm{Pb}$ sphene date ${ }^{5}$, a $64 \pm 5 \mathrm{Ma} \mathrm{Rb} / \mathrm{Sr}$ biotite date, and a 66.7 $\pm 5.0 \mathrm{Ma}$ $\mathrm{K} / \mathrm{Ar}$ biotite date on the Zion Hill Bridge body, as well as a 55.4 $\pm 5 \mathrm{Ma} \mathrm{K} / \mathrm{Ar}$ feldspar date on the Hall Green pluton that likely is a minimum age. Chubb and Burke also reported a $75.5 \pm 5 \mathrm{Ma} \mathrm{K} / \mathrm{Ar}$ feldspar date on the Troja pluton. Lewis and others (1973) reported discordant hornblende and whole-rock K/Ar dates of $48.2 \pm 1.8$ and $74.3 \pm 2.0 \mathrm{Ma}$, respectively, on the Ginger Ridge granodiorite (all K/Ar dates recalculated, as needed, to reflect constants of Steiger and Jager, 1977); whole-rock date likely is spurious. On eastern Saint Thomas in U.S. Virgin Islands, several quartz-andesine porphyry dikes that trend northeastward and, to lesser extent, northwestward cut unit Kkp, keratophyre of the Water Island Formation (Donnelly, 1966); age of these dikes is only inferred

TKtm Granitic rocks, granodiorite, and tonalite (Tertiary, Paleocene to Late Cretaceous, Maastrichtian?)Main exposure of unit is granodiorite and tonalite in northwest-trending belt across island of Hispaniola. Mapped as tonalite in Dominican Republic (Toloczyki and others, 1991) and as granodiorite and tonalite in Massif du Nord in Haiti (Vila and others, 1985); also includes small outlier plutons in eastern Dominican Republic.

Radiometric ages, by either $\mathrm{K} / \mathrm{Ar}$ or ${ }^{40} \mathrm{Ar} /{ }^{39} \mathrm{Ar}$ methods, range from $33 \pm 2$ to $83.0 \pm 9.2 \mathrm{Ma}$; however, most analytically reliable ages are between $56 \pm 2$ and $70.5 \pm 0.8 \mathrm{Ma}$. The outlier age determinations are suspect, owing to abnormal $\mathrm{K}_{2} \mathrm{O}$ contents, discordance, or low-quality analyses.

Several of these plutons in Dominican Republic, especially the eastern outlier bodies, yielded age determinations indicating that they more likely belong to either the quartz diorite and diorite unit (TKqt), the granodiorite subunit (Kgd), or the granodiorite and tonalite unit (Kmgd), and they have been reassigned here as appropriate.

On Isla de Vieques in Puerto Rico, small "mafic" intrusive bodies intrude the larger quartz diorite batholith (Learned and others, 1973)

TKqt Quartz diorite and diorite (Tertiary, Paleocene to Late Cretaceous, Maastrichtian?) - In eastern Dominican Republic, a belt of small diorite plutons intrude metavolcanic rocks of the Maimon Formation (mapped as the metavolcanic and meta-volcaniclastic rocks unit [Kmv] here) and magmatic-arc complex of the Pervillo Formation (mapped as the intermediate-composition volcanic rocks unit [Kevi] here) (Toloczyki and others, 1991); none of the plutons has been dated.

In Puerto Rico, small, largely undated, porphyritic diorite and porphyritic hornblende diorite plutons or stocks are widely scattered across island. Also, several radiometric ages have been determined on hydrothermally altered rocks in Cala Abajo and Piedra Hueca ore zones, yielding middle Eocene ages of about 40 to $42 \mathrm{Ma}$; other dates in this immediate area on rocks containing unaltered hornblende are in the same age range, suggesting that, at least locally, unit may include middle Eocene plutons. Banks (1962) mapped an undated diorite pluton on Isla de Culebra; Learned and others (1973) mapped a large quartz diorite, diorite, and granodiorite batholith on Isla de Vieques.

In U.S. Virgin Islands, small diorite plutons are present on east end of Thatch Cay, on Buck and Capella Islands, and on Frenchman Cap (Donnelly, 1966); Donnelly (1966) also mapped several andesine-hornblende porphyry dikes on Saint Thomas that we include here. Whetten (1966) mapped a hornblende diorite pluton on eastern Saint Croix; none of these intrusions in U.S. Virgin Islands has been dated

TKgb Fountain Gabbro (Tertiary, Paleocene or Late Cretaceous, Campanian?)_-Two-pyroxene gabbro that has accessory biotite, magnetite, and apatite (Whetten, 1966) on northwestern Saint Croix; body is about $3.5 \times 2 \mathrm{~km}$ in size, and it intrudes the volcaniclastic sandstone and mudstone subunit (Kvss)

\section{CRETACEOUS INTRUSIVE ROCKS}

Kgb Gabbro (Cretaceous) - Gabbro and diabase of presumed Late Cretaceous age, primarily in northern Cuba but also in central and southeastern Cuba (Pushcharovsky and others, 1988). Also includes gabbro of the Careen Hill Intrusive Suite of Rankin (2002) at Bovocoap Point on southwestern Saint John in U.S. Virgin Islands; gabbro, which is of presumed Early Cretaceous age, is dark greenish gray, fine grained, and porphyritic. Unit also likely includes mafic dikes in the Water Island Formation, which Rankin (2002) suggested may be more abundant than what is shown on his map

Kgu Granitic rocks, undivided (Late Cretaceous) - Granitic and hypabyssal rocks of presumed Late Cretaceous age, exposed in central Cuba (Pushcharovsky and others, 1988) and in southeastern Puerto Rico (Krushensky and Schellekens, 1999).

In Cuba, unit consists of undivided granodiorite, quartz diorite, subvolcanic rhyolite, and dacite.

${ }^{5}$ This is likely a $\mathrm{Pb}$-alpha date, which are considered spurious as the method was based on invalid assumptions. 
In Puerto Rico, unit includes granodiorite and quartz diorite of plutonic complex of Punta Guayanes, as well as granodiorite of San Lorenzo. Radiometric ages are apparently not available for these bodies, and so age is inferred.

Locally, divided into subunits Klg, Klqm, Kgd, Kqd, and Kdh

Klg Granite (Late Cretaceous, Maastrichtian and Campanian) - In central and southern Cuba, consists of granite and lesser granodiorite and aplitic syenite, in small bodies (Pushcharovsky and others, 1988). Hall and others (2004) reported biotite ${ }^{40} \mathrm{Ar} /{ }^{39} \mathrm{Ar}$ total-fusion and plateau ages of $60.1 \pm 0.3$ and $65.8 \pm 0.6$ Ma, respectively, on syenitic facies of Camagüey batholith, which they (Hall and others) interpreted as indicating emplacement age of $70 \mathrm{Ma}$ or older. Other plateau age determinations on batholith varied between 68.4 and $79.9 \mathrm{Ma}$ (Hall and others, 2004)

Klqm Quartz monzonite and similar rocks (Late Cretaceous, Maastrichtian and Campanian) - In southern Cuba, consists of what Pushcharovsky and others (1988) called "granosyenite" (quartz syenite?), syenite, and other granitic rocks in an undivided unit of the Camagüey batholith, considered Late Cretaceous in age (Pushcharovsky and others, 1988; their unit "Kg-gd"). Hall and others (2004) described a syenitic facies and a granodioritic facies; however, neither of these facies designations by Hall and others (2004) match unit assignments of Pushcharovsky and others (1988), clearly indicating an undivided unit. Age determinations by Hall and others (2004), as specified for the granite subunit (Klg) above, confirm age assignment of this group of plutons to the Campanian and Maastrichtian.

In Puerto Rico, quartz monzonite of plutonic complex of Punta Guayanes is a small body within larger Late Cretaceous plutonic complex and is not dated

Kgd Granodionite (Late Cretaceous, Maastrichtian and Campanian) - In southeastern Puerto Rico, the granodiorite of San Lorenzo of Krushensky and Schellekens (1999) grades into quartz diorite and, locally, into quartz monzonite, forming a large pluton of nearly $300 \mathrm{~km}^{2}$; satellite bodies are mapped as the undivided granitic rocks unit (Kgu) and the quartz monzonite and similar rocks subunit (Klqm)

Kqd Quartz diorite (Late Cretaceous, Maastrichtian and Campanian) - In southern Cuba, consists of several small quartz diorite plutons that apparently intrude plutons of the quartz monzonite and similar rocks subunit (Klqm), volcanic rocks of the intermediate and mafic pyroclastic rocks subunit (Kwt), and rocks of the metavolcanic and meta-volcaniclastic rocks unit (Kmv) (Pushcharovsky and others, 1988).

In southeastern Dominican Republic, the tonalitic Medina stock has been dated by K/Ar at 80.9 \pm 2.0 Ma on hornblende (Bowin, 1975; Kesler and others, 1991).

In southeastern Puerto Rico, other small quartz diorite plutons assigned to plutonic complex of Punta Guayanes and granodiorite of San Lorenzo intrude either other (older) plutons of these units or the undivided volcanic rocks unit (Kvr) (Krushensky and Schellekens, 1999)

Kdh Diorite and hornblendite (Late Cretaceous, Maastrichtian and Campanian) - In central and southern Cuba, small diorite bodies (Pushcharovsky and others, 1988); in southern and southeastern Puerto Rico, small diorite and hornblendite bodies (Krushensky and Schellekens, 1999).

In Cuba, Rojas-Agramonte and others (2010) reported U/Pb sensitive high-resolution ion microprobe (SHRIMP) zircon age determinations on two of these plutons: tonalite from the San Andres body yielded an age of $74.8 \pm 0.7 \mathrm{Ma}$, and granite from same body yielded an age of $76.3 \pm 0.5 \mathrm{Ma}$. The trondhjemite of the Tres Guanos body to southeast yielded an age of $71.1 \pm 0.4 \mathrm{Ma}$ on seven grains (one grain from sample yielded a highly anomalous age of 536 \pm 3 Ma, suggesting that zircon was inherited).

In Puerto Rico, bodies include mixed granodiorite-diorite of the San Lorenzo Complex and hornblende diorite and hornblende gabbro; gabbro was described as intruding diorite (Krushensky and Schellekens, 1999)

Kmgd Granodiorite and tonalite (Cretaceous, Santonian to Albian) - In central Cuba, granodiorite, tonalite, and subordinate granitic rocks in several plutons. Rojas-Agramonte and others (2011) reported U/Pb SHRIMP zircon age determinations that yielded a tight range of ages between $87.2 \pm 1.2$ and $89.3 \pm 2 \mathrm{Ma}$.

In eastern Dominican Republic, plutons mapped by Toloczyki and others (1991; their unit "ks-tpgto") yielded radiometric ages between 106 and $109 \mathrm{Ma}$ (K/Ar; Escuder Viruete and others, 2006b) and 112.9 $\pm 0.9 \mathrm{Ma}(\mathrm{U} / \mathrm{Pb}$; Kesler and others, 2005a).

In central Puerto Rico, the Morovis and Ciales stocks are granodiorite, which grades to quartz monzonite in the Morovis stock (Krushensky and Schellekens, 1999). A K/Ar age on hornblende from quartz monzonite of the Morovis stock was 90.2 $\pm 1.8 \mathrm{Ma}$ (Cox and others, 1977; recalculated using constants of Steiger and Jager, 1977). East of these is the undated Caguas pluton, also granodiorite, which, according to Krushensky and Schellekens (1999), is foliated near its contacts and has autoclastic intrusion breccia near its margins. Hornblende-rich autoliths(?) or xenoliths(?) are common locally

Kmq Trondhjemite and keratophyre (Early Cretaceous) — Southwest of Saint John, on Leduck and Flanagan Islands in U.S. Virgin Islands, Rankin (2002) mapped small trondhjemite and intrusive keratophyre 
bodies as part of the Careen Hill Intrusive Suite. Hypabyssal keratophyre is included in the hypabyssal rocks and keratophyre porphyry unit (Khk). The trondhjemite is fine to medium grained and commonly porphyritic and has quartz and twinned, nonzoned albite phenocrysts, in a groundmass that typically is a granophyric intergrowth between quartz and albite. On Leduck Island, columnar jointing is prominent Rankin (2002). Larger keratophyre intrusive bodies form sharp, isolated hills along south coast of Saint John and around harbor of Charlotte Amalie, Saint Thomas. Rankin (2002) reported that keratophyre also is found as clasts in tuff breccia of Water Island Formation (unit Kwi) on eastern Saint John; Rankin (2002) suggested an Early Cretaceous age for unit. Helsley (1960) included Flanagan Island as part of the Tertiary Virgin Gorda batholith (mapped as the granite and granodiorite unit [Tegr] here); no radiometric ages are available on this map unit

\section{JURASSIC INTRUSIVE ROCKS}

Jgr Rio Cana Granite (Middle Jurassic) - In Cuba, consists of coarse-grained pink granite that contains perthitic microcline, plagioclase, quartz, biotite, and accessory apatite and zircon. According to Renne and others (1989), unit is highly deformed and commonly has cataclastic texture. Somin and Millán (1977) reported several whole-rock K/Ar dates between 136 and $146 \mathrm{Ma}$; however, they are suspect because they are whole-rock dates on granitic rock. Renne and others (1989) reported a multigrain U/Pb analysis that yielded a lower intercept age of $172.5 \mathrm{Ma}$ and an upper intercept of about $900 \mathrm{Ma}$. This upper intercept age is similar to an age obtained by Somin and Millán (1977) for phlogopite in marble (the marble unit $[\mathrm{Mzm}]$ ) that was intruded the granite

\section{METAMORPHIC ROCKS}

\section{MESOZOIC METAMORPHIC ROCKS}

$\mathrm{Mzm} \quad$ Marble (Mesozoic or older) - Marble of indefinite age, mapped in northern part of central Cuba and at east end of Península de Samaná (Samaná Peninsula) in Dominican Republic. Pushcharovsky and others (1988) described the Sierra Morena Marble in Cuba as a phlogopite-bearing marble of Precambrian age; however, the complete lack of any other rocks even as old as Paleozoic anywhere in the Greater Antilles suggests that this age is unlikely. Toloczyki and others (1991) mapped massive or thick-bedded marble on Peninsula de Samaná but did not assign an age; however, unit is locally associated with metasedimentary rocks of presumed Jurassic age (mapped as the metasedimentary rocks, including marble unit [Jm] and the metamorphic complexes characterized by glaucophane schist unit [Jsch] here)

Kmgb Gabbroic amphibolite and amphibolite (Cretaceous?) - Gabbroic amphibolite and amphibolite of the greenschist-facies Duarte Formation of Cordillera Central and Cordillera Septentrional of Dominican Republic (Toloczyki and others, 1991)

KJcm Mariquita Chert (Cretaceous, middle Turonian? to Jurassic, early Tithonian to late Kimmeridgian) In southwestern Puerto Rico, the Mariquita Chert is laminated, fine-grained, dark-gray chert that is locally interbedded with recrystallized and largely silicified limestone and nonmetamorphosed pillow basalt (Krushensky and Schellekens, 1999); chert has abundant to sparse radiolaria and, locally, foraminifera (Krushensky and Schellekens (1999)

Kgs Marble and greenschist (Cretaceous, Cenomanian or older) - In both U.S. and British Virgin Islands, two marble units are recognized, the Outer Brass Limestone (Donnelly, 1966; Rankin, 2002) and the Congo Cay Limestone Lens of the Mandal Member of the Tutu Formation (Rankin, 2002). The Outer Brass Limestone is about $100 \mathrm{~m}$ of thin-bedded, partially silicified, radiolarian-bearing limestone that contains about 10 percent interbedded crystal tuff, in beds as much as $1 \mathrm{~m}$ thick (Helsley, 1960; Donnelly, 1966; Rankin, 2002); exposed on Outer Brass Island, Saint Thomas, and Saint John, unit thins to east. "The formation is nowhere exposed in the British Virgin Islands and, since exposures are present in the interval in which it should occur, it probably never was deposited in the British Virgin Islands" (Helsley (1960). "Nearly all thin sections of limestone contain a small percentage of angular plagioclase and augite crystals, the product of sporadic eruptions from an unknown source" (Donnelly, 1966). On northern Saint John, epidote, brown isotropic garnet, diopside, vesuvianite, and wollastonite are developed near contact with the Narrows pluton (Rankin, 2002). The Congo Cay Limestone Lens (Helsley, 1960; Donnelly, 1966; Rankin, 2002) is exposed on Congo Cay in U.S. Virgin Islands and Great Thatch Island and Tortola in British Virgin Islands. Rankin (2002) described it as tightly folded, vertical beds of marble, calcsilicate rock, and siliceous hornfels exposed on Congo Cay and Carval Rock; Helsley (1960) placed it near top of the Tutu Formation in British Virgin Islands where it is exposed in context, as coarsely crystalline limestone containing poorly preserved gastropod molds. The Congo Cay Limestone varies in thickness; Helsley (1960) reported usual thickness is about $120 \mathrm{~m}$ in western part of Tortola. 
Unit here also includes marble conglomerate of the Picara Member of the Tutu Formation on northern Saint John (Rankin, 2002)

Kmv Metavolcanic and meta-volcaniclastic rocks (Early Cretaceous) - In Cuba, Pushcharovsky and others (1988) mapped two areas of metavolcanic rocks. Largest area is in southeastern Cuba, in vicinity of Guantánamo where the La Farola Formation is described as undifferentiated metaigneous rocks; Pardo (2009) considered this a "wastebasket" unit that includes all metavolcanic rocks of the Sierra del Purial; unit is synonymous with the Purial complex of Millán and Somin (1985) and Millán-Trujillo (1996), who divided it into five sequences, which are, from east to northwest, Rio Baracoa, Jojo, Loma Quivican, Via Mulata, and Mal Nombre. Millán and Somin (1985) defined the Rio Baracoa sequence as a mostly pyroclastic and sedimentary section that has common polymictic and quartz-feldspar sandstone, as well as limestone; metamorphism is irregular and ranges from low grade and prehnite bearing to rare blueschist facies with lawsonite and glaucophane. The Jojo sequence of Millán and Somin (1985) is characterized by mafic pyroclastic rocks, though andesitic and rhyodacitic rocks are also present. It also has polymictic, medium-grained metasandstone that contains volcanic clasts and quartz and isolated beds of fine-grained, actinolite schist, rich in graphite, containing albite, quartz, chlorite, and glaucophane; the Jojo sequence shows similarity to the (nonmetamorphosed) Santo Domingo Formation (mapped as the intermediate and mafic pyroclastic rocks unit [Kwt] here) (Pardo, 2009). Millán and Somin's (1985) Loma Quivican sequence is nonmetamorphosed to slightly metamorphosed tuff and poorly bedded tuff breccia; clasts in breccia of porphyritic basalt have low $\mathrm{TiO}_{2}$ and $\mathrm{K}_{2} \mathrm{O}$ contents, as well as a high $\mathrm{Al}_{2} \mathrm{O}_{3}$ content, characteristic of tholeiite; metamorphic grade is so low that volcanic glass is unaltered. Pardo (2009) described the Via Mulata sequence as follows:

"The Via Mulata sequence (named by Millán-Trujillo, 1996) outcrops in the northwestern part of the Sierra del Purial complex and consists of a sequence of well-bedded metatuff showing rhythmic sedimentation. Medium- to fine-grained tuffs can be recognized, and the color varies from green to lilac with a slaty luster. Occasionally, light-colored slaty limestones occur. This sequence could represent a lateral equivalent of the Loma Quivican" (Pardo, 2009).

Finally, the Mal Nombre sequence of Millán and Somin (1985), crops out in extreme northwestern part of the Sierra del Purial complex and is homogeneous, massive to poorly bedded, polymictic, generally poorly sorted, angular, and coarse-grained metasandstone to brecciated metaconglomerate. This sequence is similar to some of the clastic rocks of Rio Baracoa sequence and could be a metamorphic equivalent of the Micara Formation (mapped as the mixed volcanic and clastic rocks subunit [TKvc] here) or the La Picota Formation (mapped as the undifferentiated clastic rocks unit [Ku] here). Metamorphism of the La Farola Formation is characterized by glaucophane and decreases in grade from southeast to northwest (Pardo, 2009); "By similarity with other volcanic section, the La Farola Formation may extend from the Aptian(?) through the Maastrichtian" (Pardo, 2009). The Yaguanabo Formation of central Cuba (Pushcharovsky and others, 1988) is greenschist-facies metavolcanic rocks that have layers of marble and metachert and are associated with Jurassic metamorphic rocks and the Mabujina Complex that form the Trinidad Dome; as mapped by Pushcharovsky and others (1988), the Yaguanabo Formation includes fine-grained, foliated, locally tuffaceous limestone, well-bedded, locally manganese-stained quartzite and interbedded quartz-mica schist. It rarely includes marble and well-bedded, rhythmically bedded, fine-grained chlorite schist and metasandstone, thought to represent flysch deposits (Pardo, 2009).

In Dominican Republic, the Maimon Formation, located on north side of Cordillera Central, is metamorphosed keratophyre, quartz keratophyre, tuff, and other volcanic rocks (Toloczyki and others, 1991). It is considered of Early Cretaceous age and may correlate with the Water Island Formation (unit Kkp) of Virgin Islands.

In Haiti, in Massif du Nord, roughly on trend with the Maimon Formation in Dominican Republic, are undifferentiated metamorphic rocks consisting of gneiss, mica schist, amphibolite, and chlorite schist (Vila and others, 1985). On the western part of Île de la Tortue, lower greenschist facies metatuff, metarhyolite, and metachert alternate with well-exposed white marble (Vila and others, 1985); on the eastern part of Île de la Tortue, calcschist contains microfauna of latest Cretaceous age (Vila and others, 1985)

KJmc Mabujina Complex and equivalent rocks (Early Cretaceous or Late Jurassic) - The Mabujina Complex, which structurally underlies nonmetamorphosed volcanic-arc rocks, is composed of gabbro, basalt, basaltic andesite, and pyroclastic rocks that were deformed and metamorphosed to greenschist and amphibolite facies (Somin and Millán, 1981; Blein and others, 2003; Iturralde-Vinent and others, 2016). Considered autochthonous, Blein and others (2003) indicated that the Mabujina Complex rocks are tholeiitic and calc-alkaline basalt, part of a Jurassic and (or) Early Cretaceous intraoceanic island arc, and 
that their isotopic compositions indicate depleted mantle source contaminated by sediments. Blein and others (2003) interpreted that magmatism is not related to classic Early Cretaceous Caribbean tholeiitic series but is similar to the Late Jurassic to Early Cretaceous Guerrero arc terrane from Mexico and may represent its southernmost extension; their data indicated that two different island arcs were tectonically juxtaposed in central Cuba, (1) the classical Lower and Upper Cretaceous suites of the Greater Antilles arc, and (2) a Jurassic to Early Cretaceous island-arc suite that has a paleo-Pacific Ocean provenance. They additionally interpreted that different tectonic units of central Cuba cannot be easily correlated with those of the island of Hispaniola. In southernmost Cuba, rocks of the Guira de Jauco Formation are undifferentiated amphibolite, feldspar-epidote-amphibolite schist, gneiss, and metachert (Pushcharovsky and others, 1988).

In southwestern Puerto Rico, basaltic rocks of the Bermeja Complex vary from weakly metamorphosed, prehnite-bearing rocks, through greenstone, to amphibolite facies. Schellekens and others (1990) described unit, the oldest dated rocks on Puerto Rico, as follows:

"Previous workers (eg. Mattson, 1973, Mattson and Pessagno, 1974, 1979, Wadge and others, 1983) have regarded the Bermeja Complex as representing a dismembered ophiolite complex. However, the evidence is ambiguous and it could also represent island arc basement. *** The Bermeja Complex was first described by Mattson (1960), who distinguished four rock types: serpentinized peridotite (Mattson, 1960, 1964), spilite (here named the Las Mesas Greenstone), amphibolite (later named the Las Palmas Hornblende Schist and Amphibolite; Mattson, 1973), and silicified volcanic rock and/or chert (later named the Mariquita Chert by Mattson, 1973)."

Schellekens and others (1990) described three belts of serpentinite in the Bermeja Complex, each of which also contain greenstone and locally may contain volcaniclastic conglomerate and sandstone. These serpentinite belts are mapped as part of the serpentinite unit (Mzs). The Mariquita Chert is finegrained, greenish-gray or black, radiolarian-bearing chert; Schellekens and others (1990) reported that it can be divided into three chert-forming episodes that are based on the radiolaria. These are Kimmeridgian to Tithonian, Hauterivian to lower Albian, and Cenomanian to Turonian.

Locally, divided into subunit Ktg

Ktg Metaigneous rocks (Early Cretaceous, Hauterivian to Berriasian) — In Cuba, mapped as Paleozoic metagranite, called the Mabujina Granite by Pushcharovsky and others (1988). Rojas-Agramonte and others (2011) reported an Early Cretaceous U/Pb SHRIMP age (on six grains) of 132.9 $1.4 \mathrm{Ma}$ and a multigrain conventional zircon age of $133 \pm 2 \mathrm{Ma}$ on trondhjemitic orthogneiss, indicating that unit is likely Early Cretaceous in age. According to Rojas-Agramonte and others (2011), field relations show that there are several generations of granitoid rocks that are variably foliated and boudinaged and locally, strongly folded, having significant strain gradients

KJyb Metasedimentary and metaigneous rocks (Early Cretaceous or Late Jurassic, Tithonian) - In southeastern Cuba, the Sierra Verde Formation is about 80 percent black, graphitic phyllite and metamorphosed shale, which weathers pinkish, violet, creamy, or greenish and has beds of metalimestone, metamorphosed mafic volcanic rocks, and metamorphosed chert (Pardo, 2009). Gray, schistose, laminated metalimestone locally has small remnants of noncrystallized, cream limestone in which microfossils have been found. Fauna consists of Calpionella sp., Nannoconus sp., and undetermined Globigerinidae (Ticinella? sp. and Hedbergella? sp.), suggesting a Neocomian age, possibly extending into the Tithonian (Pardo, 2009). Pardo (2009) also reported that "common interbeds of metamorphosed chert and an argillaceous, lustrous (sericitic), meta-silicate schist showing abundant remains of radiolaria also exist."

In the Blue Mountain Inlier of eastern Jamaica, McFarlane and others (1984) lumped three different schist units together that they called the Westphalia and Mount Hibernia Schist Groups and the Green Bay Metamorphics. Using slightly different terminology, Hastie (2007) described the Westphalia schist as having a sedimentary or volcaniclastic protolith metamorphosed to amphibolite facies and as having a calc-alkaline affinity. Lewis and others (1973) reported discordant K/Ar ages on the schist of 49.9 \pm 1.3 and 54.1 $\pm 1.4 \mathrm{Ma}$ on biotite and 78.2 $\pm 2.1 \mathrm{Ma}$ on hornblende. The Green Bay schist, located southwest of Kingston, Jamaica, is described as having a similar character to the Westphalia schist (Hastie, 2007). The Mount Hibernia schist is described by Hastie (2007) as having an ultramafic to mafic tholeiitic protolith metamorphosed to blueschist and greenschist facies

KJmq Cobrito Formation (Early Cretaceous to Late Jurassic) — In central Cuba, flysch-like beds of metamorphosed carbonate and clastic rocks are associated with the Trinidad Dome (Pushcharovsky and others, 1988). Pardo (2009) described unit as succession of calcareous schist and schistose marble layers that have fine, rhythmic stratification. "Commonly included in the schists are small boudins, less affected by 
the metamorphism, of black dolomitic and crystalline limestone, with radiolaria (Spumellaria spp. and Nassellaria? spp.) and other organic remains. Some of the fossils have been tentatively identified as the Upper Jurassic-Neocomian Globochaetes alpina and Cadosina sp." (Pardo, 2009)

\section{JURASSIC METAMORPHIC ROCKS}

Jsch Metamorphic complexes characterized by glaucophane schist (Jurassic?) - Unit comprises variety of metasedimentary schist units, all characterized by presence of glaucophane and other blueschist-facies minerals. In each of these units, age is inferred.

In central Cuba, the Algarrobo Schist, which is associated with older rocks of Trinidad Dome, is a variety of quartz-garnet-mica, glaucophane-quartz-garnet-mica schist and, locally, hornblende schist and calcschist. Pushcharovsky and others (1988) mapped several small metamorphic complexes scattered throughout central and southern Cuba that all contain quartz-mica schist and glaucophane schist and variably contain eclogite, marble, amphibolite, and phyllite. Metavolcanic rocks are present locally in some discrete units, as mapped by Pushcharovsky and others (1988).

In the northeastern part of Dominican Republic, Toloczyki and others (1991) mapped micaceous schist on Peninsula Samaná that they described as locally including eclogite and blueschist

Jm Metasedimentary rocks, including marble (Jurassic) - Mapped in Cuba and Dominican Republic, metasedimentary rock units here are similar to those of the metamorphic complexes characterized by glaucophane schist unit (Jsch), except for indications of blueschist-facies metamorphism.

On Isla de la Juventud off the coast of Cuba, the Agua Santa, Canada, and Isla de la Juventud Formations consist of metasedimentary schist, locally graphitic, and marble (Pushcharovsky and others, 1988). Pardo (2009) described rocks as having an antiformal dome-like structure and divided them into five metamorphic-grade zones, the lowest grade being in the center. Pardo's (2009) description is paraphrased as follows:

Mineral assemblages in schist range from quartz-muscovite-biotite, quartz-muscovite-biotitechlorite, quartz-muscovite-chlorite, and quartz-muscovite in lowest grade (zone I) to garnetbiotite-muscovite, kyanite-biotite-muscovite, staurolite-biotite-muscovite, staurolitemuscovite, garnet-muscovite, staurolite-biotite-chlorite-muscovite, and zoisite-biotitemuscovite in zone II. In zone II, calc-silicate rocks contain some diopside and potassium feldspar, suggesting low-amphibolite facies. In zone III, assemblages include kyanitestaurolite-muscovite, kyanite-staurolite-biotite-muscovite, kyanite-staurolite-andalusitemuscovite, kyanite-muscovite, and garnet-muscovite, where kyanite and staurolite are abundant. In zone IV, metasedimentary schist contains assemblages that represent all combinations of garnet, kyanite, staurolite, muscovite, biotite, sillimanite, and andalusite; calc-silicate rocks and some marbles contain diopside (commonly partially replaced by tremolite or actinolite); calc-silicate rocks also contain calcic plagioclase, calcite, scapolite, zoisite, epidote, hornblende, phlogopite, and potassium feldspar. Contacts between zone IV and zones I, II, and III are tectonic, and contacts between zones IV and V are gradational. Zone V, which is transitional to, and appears included within, zone IV, consists mostly of gneiss that displays intense migmatization and granitization, as shown by bands of gneiss interbedded with bands of granite that commonly are intensely contorted (Pardo, 2009).

Pardo (2009) suggested that the Agua Santa and Canada Formations are equivalent to the San Cayetano Formation (Jvs).

In the northern part of Cuba, the Arroyo Cangre Formation was described by Pushcharovsky and others (1988) as metasandstone, chlorite-muscovite schist, marble, and metavolcanic rocks, which structurally underlie the limestone and dolostone unit (Jlc).

In central Cuba, the Trinidad Dome area is locale of several other presumably Jurassic-age metasedimentary complexes. Most extensive of these are the Chispa and Felicidad Formations, consisting of quartz-muscovite schist, metavolcanic rocks, marble, and metachert, and the more quartz-rich Naranjo Formation, which also includes quartz-chlorite schist and marble. Associated with the southern exposure of the Naranjo Formation is unnamed unit of marble and greenschist (see also, DespaigneDiaz and others, 2016, for discussion of these units). In the same area, Pushcharovsky and others (1988) mapped dark-blue-gray to black marble, carbonaceous and graphitic schist, chlorite schist, and amphibolite that Pardo (2009) called the San Juan Group; Pardo (2009) estimated that the San Juan Group represents 40 to 45 percent of the Trinidad Dome area metamorphic province. Pardo (2009) described several formations as part of the San Juan Group including the Narcisco, Sauco, and Mayari Formations, one of which, the Narcisco Formation, has ammonite fossils that indicate a middle Oxfordian age. 
In extreme southeastern Cuba, the Chafarina Formation consists principally of dark-gray marble, which is locally dolomitic, and muscovite-bearing calc-schist. Dark-gray to black chert is locally present and may be abundant (Pardo, 2009).

In eastern Dominican Republic, on Peninsula Samaná, micaceous schist and marble are widely exposed. Age control is not available for this unit; however, Toloczyki and others (1991) mapped it as Mesozoic

Jmg Mafic schist and amphibolite (Late to Middle Jurassic) - In central Cuba, the Yayabo Formation has very limited exposure on the south edge of Sancti Spiritus Dome and consists of garnetiferous amphibolite, garnetiferous meta-quartzite, and amphibolitic eclogite. Amphibolite contains felsic plagioclase, white mica, and clinozoisite (Pushcharovsky and others, 1988). Although exposures of the Yayabo Formation are not far from those of the Mabujina Complex (KJmc), Pardo (2009) indicated that the Yayabo Formation is distinct, both petrographically and chemically, from the Mabujina Complex.

In Dominican Republic, the Duarte Complex, which forms the north-central part of Cordillera Central, is mafic schist and, locally, diabase (Toloczyki and others, 1991); inferred to be of Late Jurassic age, it is extensively intruded by latest Cretaceous plutons of the granitic rocks, granodiorite, and tonalite unit (TKtm). Escuder Viruete and others (2007b) reported a ${ }^{40} \mathrm{Ar} /{ }^{39} \mathrm{Ar}$ plateau age of 93.95 \pm 1.37 Ma on hornblende from amphibolite, suggesting Cretaceous metamorphism; Kesler and others (1977) reported $\mathrm{K} / \mathrm{Ar}$ ages on hornblende and plagioclase of $125.5 \pm 1.8$ and 126.1 $\pm 1.8 \mathrm{Ma}$ (recalculated using constants of Steiger and Jager, 1977), respectively, on amphibolite

Jvs San Cayetano Formation (Jurassic, Oxfordian to Early Jurassic) - Widely exposed in northwesternmost Cuba, the San Cayetano Formation is undifferentiated sandstone, mudstone, argillite, and phyllitic schist. Its Castellano member, which tends to be exposed in the northwestern part of formation, is phyllitic schist that has carbonaceous layers, argillite, siltstone, and limestone beds; it is considered the upper part of the San Cayetano Formation (Pushcharovsky and others, 1988). Pardo (2009) described the San Cayetano Formation as thick monotonous section of dominantly dark-gray to black shale, sandstone, and siltstone that weathers to white, grayish orange, red, or grayish black. Upper part has sparse interbeds of conglomerate and limestone. Pardo (2009) reported that "because of the intense deformation and the monotonous nature of the section, no reliable thickness measurements exist"; however, estimates range from 1,500 to as much as $5,000 \mathrm{~m}$ thick

\section{OPHIOLITE AND OPHIOLITE-ASSOCIATED ROCKS}

MzS Serpentinite (Cretaceous or Jurassic?) - In eastern Jamaica, in the southwestern part of the Blue Mountain Inlier (McFarlane and others, 1984), small bodies of serpentinite are found that, according to Arden (1975), are likely of Late Cretaceous age.

In southwestern Puerto Rico, serpentinite is common in a northwest-trending belt of exposures in the Bermeja Complex, the amphibolite of which is included in the Mabujina Complex and equivalent rocks unit (KJmc). The serpentinite consists of sheared, light- to dark-green, altered harzburgite; also includes poorly sorted, unsheared, epiclastic serpentinite (Krushensky and Schellekens, 1999). Schellekens and others (1990) described three belts of serpentinite in the Bermeja Complex, each of which also contains greenstone and locally may contain volcaniclastic conglomerate and sandstone. The northernmost of the belts is intruded by gabbro, and the other belts, by small basaltic and andesitic intrusions

Mzmd Mafic rocks, diorite, and gabbro (Mesozoic or older) - In eastern parts of central and southern Cuba, consists of undifferentiated metaigneous rocks, including ultramafic and mafic metamorphic rocks, serpentinite schist, talc schist, antigorite-rich schist, and metagabbro (Pushcharovsky and others, 1988).

In northeastern Dominican Republic in Cordillera Central and Cordillera Septentrional, consists of gabbro-norite and gabbroic complexes and pyroxenite that are ophiolite associated (Toloczyki and others, 1991). Age control is lacking; however, rocks are associated with Cretaceous and Jurassic metamorphic complexes

Mzum Ultramafic and associated rocks (Mesozoic or older) —Widespread in Cuba; also present on island of Hispaniola, in Haiti and Dominican Republic.

In Cuba, Pushcharovsky and others (1988) mapped undifferentiated metaigneous rocks unit that consists of serpentinite, harzburgite, lherzolite, wehrlite, and serpentinized dunite; found throughout Cuba, generally in the northern and eastern parts of island. In northern Cuba, ultramafic bodies are typically in small, spatially separate plutons and belts. In central and southern Cuba, ultramafic bodies and complexes tend be much larger.

In Dominican Republic, small pyroxenite bodies present in Cordillera Central are associated with the mafic rocks, diorite, and gabbro unit (Mzmd) (Toloczyki and others, 1991). An extensive belt, about 
$90 \mathrm{~km}$ long, of ultramafic rocks is present along the southeastern margin of Cordillera Central; other ultramafic rocks are found on north coast of Cordillera Septentrional (Toloczyki and others, 1991).

In Haiti, like northern Cuba, several small ultramafic bodies are present in Massif du Nord and on western tip of the southern peninsula; these are associated with volcanic rocks of the basalt, pillowed and nonpillowed flows, breccia, and tuff unit (KImv) (Vila and others, 1985)

KJmu Dike complexes (Early Cretaceous or Late Jurassic)-Scattered mafic dike complexes in central and southern Cuba (Pushcharovsky and others, 1988)

\section{TECTONITES}

Tmo Mélange and olistostromes (Tertiary, Eocene to Paleocene) - Primarily exposed in two areas of Cuba but also present in Dominican Republic, unit consists of mélange and olistostrome deposits.

In southern Cuba in Provincia de Holguín (Holguín Province), the Paleocene Halicos Formation crops out along the southern margin of the ophiolite belt. It is a chaotic mix of blocks of serpentinite, intrusive and volcanic rocks, limestone, and tuff (Pushcharovsky and others, 1988), in a matrix of volcaniclastic sandstone, siltstone, and marl (Pardo (2009). In central Cuba, in Provincia de Camagüey (Camagüey Province), the Senado Formation of Pushcharovsky and others (1988; also called the upper Vega Formation of Pardo [2009]) has a lower unit of poorly sorted, thick-bedded sandstone, silty shale, and conglomerate and an upper unit of mélange that consists of blocks of limestone and serpentinite, in a sandstone and siltstone matrix (also called the Rosas Formation of Pardo [2009]). The Paleocene Taguasco Formation, the Paleocene to Eocene Vega Alta Formation, and the Eocene Vega Formation (or the Brecha Sagua Formation) of Pushcharovsky and others (1988) are found in a linear belt northeast of the Trinidad-Sancti Spiritus Dome area of central Cuba. The Taguasco Formation is described as sandstone and conglomerate; conglomerate contains boulders of nonweathered, felsic granitic rocks (Pardo, 2009). Pardo (2009) suggested that the Taguasco Formation is synorogenic and was deposited as the mafic- and ultramafic-rock complex was thrust over the northern carbonate belts. Pushcharovsky and others (1988) described the Vega Alta Formation as a chaotic mix of blocks of limestone, serpentinite, and volcanic rocks, in a clayey matrix, and the Vega Formation (or Brecha Sagua Formation) as "breccia, conglomerate, limestone, sandstone, siltstone, marl, claystone." Pardo (2009) considered these formations as a mix of multiple other formations, including the Sagua, Vega, and San Martin Formations.

In Dominican Republic, the San Marcos Olistostrome was thought of as Quaternary by Toloczyki and others (1991). However, Hernaiz Huerta and others (2012) indicated that a middle Eocene age was more appropriate, and they described the San Marcos Formation as an olistostrome that contains exotic blocks of carbonate rocks and clastic rocks, as well as olistoliths of underlying formations

TKyf Yaguajay Formation (Tertiary, Paleocene to Cretaceous, Maastrichtian) - In southern Cuba (Provincia de Holguín), the Maastrichtian to Paleocene Yaguajay Formation crops out along northern margin of the ophiolite belt and is a chaotic mix of blocks of serpentinite, gabbro, volcanic rocks, limestone, and tuff (Pushcharovsky and others, 1988), in a matrix of tuff, sandstone, and marl. Pardo (2009) considered the Yaguajay Formation as described by (Pushcharovsky and others, 1988) to be similar to (but not correlative with) the Vega Alta Formation of Pushcharovsky and others (1988); however, he (Pardo) explicitly did not consider it to be legitimate formation

Kmk Mélange (Cretaceous?) —In Dominican Republic, Toloczyki and others (1991) mapped Cretaceous(?) mélange in Cordillera Central and Cordillera Septentrional (no other description is available)

\section{TECTONICALLY AND HYDROTHERMALLY ALTERED ROCKS}

TKht Hydrothermally altered rocks (Tertiary, Eocene or Cretaceous) - Widely distributed in Puerto Rico are hydrothermally altered rocks that consist of mixed clay, sericite, albite, and pyrophyllite and are locally, pyrite bearing; most protolith were intrusive rocks (Krushensky and Schellekens, 1999)

Tfg Fault breccia (Tertiary, Eocene) - Mapped only in south-central Puerto Rico (Krushensky and Schellekens, 1999) but likely much more widely distributed; clay-rich altered rocks mapped along faults; lithology dependent on nature of country rocks surrounding faults; exposures tend to be linear and can be as much as $35 \mathrm{~m}$ thick (Krushensky and Schellekens, 1999); rocks may be cataclastic or mylonitic

bu

Bedrock of unknown type (age unknown) - Areas in Puerto Rico and elsewhere that either were not mapped or were where rock units were unidentified. Includes quartz veins on Isla de Vieques; these quartz veins cut both the pluton and country rock on the island (Learned and others, 1973) 


\section{References Cited}

[Note that references that begin with an asterisk (*) were not examined by authors]

* Adamovich, A., and Chejovich, V., 1964, Principals caracteristicas de la geologia y de los minerales utiles de la region nordeste de la Provincia de Oriente: La Habana, Ministeric de Industrias, Rev, Tecnologica, v. 2, no. 1, p. 14-20.

Albear Franquiz, J.F. de, and Iturralde-Vinent, M.A., 1985, Estratigrafia de las provincias de la Habana, in IturraldeVinent, M.A., ed., Contribucion a la geologia de las provincias de la Habana y ciudad de la Habana: Ciudad de la Habana, Editorial Cientifico-Tecnica, Ministerio de Cultura, p. 12-54.

Alioshin, V., Burov, V., Eguipko, O., Eliseev, V., Sánchez Menéndez, F., Shelagurov, V., Koñujov, A., Varvarov, V., and Lorkin, V., 1975, Sobre los resultados de los trabajos de levantamiento geológico y búsqueda en escala 1:100 000 ejecutados en las montañas de la Sierra Maestra, en la provincial de Santiago de Cuba y Granma (1972-75) Sierra Maestra nororiental-Instituto Nacional de Recursos Minerales: Havana, Cuba, Ministry of Basic Industries, Internal Report.

Alminas, H.V., Foord, E.E., and Tucker, R.E., 1994, Geochemistry, mineralogy, and geochronology of the U.S. Virgin Islands: U.S. Geological Survey Bulletin 2057, 48 p.

Arden, D.D., 1975, Geology of Jamaica and the Nicaragua Rise, in Nairn, A.E.M., and Stehli, F.G., eds., The Gulf of Mexico and the Caribbean: Boston, Mass., Springer, p. 617-661.

Arribas, A., Arribas, I., Draper, G., Hall, C., Kesler, S.E., McEwan, C., and Muntean, J.L., 2011, ${ }^{40} \mathrm{Ar} /{ }^{39} \mathrm{Ar}$ dating of alunite from the Pueblo Viejo Gold-Silver District, Dominican Republic: Economic Geology, v. 106, p. 1059-1070.

Banks, T.H., 1962, Geology of Culebra Island, Puerto Rico: Houston, Tex., Rice University, M.S. thesis, 75 p.

Barabas, A.H., 1982, Potassium-argon dating of magmatic events and hydrothermal activity associated with porphyry copper mineralization in western central Puerto Rico: Economic Geology, v. 77, p. 109-126.

Berryhill, H.L., Jr., 1965, Geology of the Ciales quadrangle, Puerto Rico: U.S. Geological Survey Bulletin 1184, 116 p.

Bibikova, E.B., Somin, M.L., Gracheva, T.V., Makarov, V.A., Millan, G., and Shukolykov, Y.A., 1988, Pervye rezul'taty U-Pb-datirovaniya metamorficheskikh porod Bol'shoj Antil'skoj dugi-Vozrast kompleksa Mabukhina Kuby [in Russian: First results of U-Pb dating of metamorphic rocks of the Greater Antillean Arc-Age of the Mabujina Complex of Cuba]: Doklady of the Academy of Sciences, v. 301, p. 924-928.

Blein, O., Guillot, S., Lapierre, H., Mercier de Lepinay, B., Lardeaux, J.M., Millán Trujillo, G., Campos, M., and Garcia, A., 2003, Geochemistry of the Mabujina Complex, central Cuba-Implications on the Cuban Cretaceous arc rocks: The Journal of Geology, v. 111, p. 89-101, https://doi.org/10.1086/344666.
Bowin, C.O., 1975, The geology of Hispaniola, in Nairn, A.E.M., and Stehli, F.G., eds., Ocean basins and marginsThe Gulf of México and Caribbean: New York, Plenum Press, v. 3, p. 501-552.

Brown, I., and Mitchell, S.F., 2010, Lithostratigraphy of the Cretaceous succession in the Benbow Inlier, Jamaica: Caribbean Journal of Earth Science, v. 41, p. 25-37.

Butterlin, J., 1960, Geologie generale de la Republique d'Haiti [in French: General geology of the Republic of Haiti]: Paris, France, Institut de Hautes Etudes de l'Amerique Latine, 194 p.

Cederstrom, D.J., 1950, Geology and ground-water resources of St. Croix, Virgin Islands: U.S. Geological Survey WaterSupply Paper 1067, 117 p.

Chubb, L.J., 1955, The Cretaceous succession in Jamaica: Geological Magazine, v. 92, p. 177-195.

Chubb, L.J., and Burke, K., 1963, Age of the Jamaican granodiorite: Geological Magazine, v. 100, p. 524-532.

Comer, J.B., Naeser, C.W., and McDowell, F.W., 1980, Fissiontrack ages of zircon from Jamaican bauxite and terra rosa: Economic Geology, v. 75, p. 117-121.

Cox, D.P., Marvin, R.F., M'Gonigle, J.W., Mcintyre, D.H., and Rogers, C.L., 1977, Potassium-argon geochronology of some metamorphic, igneous, and hydrothermal events in Puerto Rico and the Virgin Islands: U.S. Geological Survey Journal of Research, v. 5, p. 689-708.

Curet, A.F., 1986, Geologic map of the Mayaguez and Rosario quadrangles, Puerto Rico: U.S. Geological Survey Miscellaneous Investigations Series Map I-1657, scale 1:20,000.

Despaigne-Diaz, A.I., Garcia-Casco, A., Caceres Govea, D., Jourdan, F., Wilde, S.A., and Millán Trujillo, G., 2016, Twenty-five million years of subduction-accretion-exhumation during the Late Cretaceous-Tertiary in the northwestern Caribbean-The Trinidad Dome, Escambray Complex, Central Cuba: American Journal of Science, v. 316, p. 203-240.

Donnelly, T.W., 1966, Geology of St. Thomas and St. John, U.S. Virgin Islands: Geological Society of America Memoir 98, p. 85-176, 1 plate, approximate scale 1:60,000.

Donovan, S.K., 2002, Field guide to the geology of the Eocene Chapelton Formation (Yellow Limestone Group), western Central Inlier: Caribbean Journal of Earth Science, v. 36, p. 39-47.

Earle, K.W., 1924, Geology of the British Virgin Islands: Geological Magazine, v. 61, p. 339-351.

Eguipko, O., and Perez, M., 1976, Breves características petrográficas y petroquímicas de los principales tipos de rocas magmáticas en la parte central de la Sierra Maestra: Centro de Investigaciones Geológicas Serie 1, 14 p.

Escuder Viruete, J., Contreras, F., Stein, G., Urien, P., Joubert, M., Pérez-Estaún, A., Friedman, R., and Ullrich, T.D., 2007a, Magmatic relationships and ages between adakites, magnesian andesites and $\mathrm{Nb}$-enriched basalt-andesites from Hispaniola-Record of a major change in the Caribbean island arc magma sources: Lithos, v. 99, p. 151-177, https://doi.org/10.1016/j.lithos.2007.01.008. 
Escuder Viruete, J., Contreras, F., Stein, G., Urien, P., Joubert, M., Ullrich, T.D., Mortensen, J., and Pérez-Estaún, A., 2006a, Transpression and strikeslip partitioning in the Caribbean island arc-Fabric development, kinematics and Ar-Ar ages of syntectonic emplacement of the Loma de Cabrera batholith, Dominican Republic: Journal of Structural Geology, v. 28, p. 1496-1519.

Escuder Viruete, J., Díaz de Neira, A., Hernáiz Huerta, P.P., Monthel, J., García Senz, J., Joubert, M., Lopera, E., Ullrich, T.D., Friedman, R., Mortensen, J., and Pérez-Estaún, A., 2006b, Magmatic relationships and ages of Caribbean islandarc tholeiites, boninites and related felsic rocks, Dominican Republic: Lithos, v. 90, p. 161-186.

Escuder Viruete, J., Pérez-Estaún, A., Contreras, F., Joubert, M., Weis, D., Ullrich, T.D., and Spadea, P., 2007b, Plume mantle source heterogeneity through time-Insights from the Duarte Complex, Hispaniola, northeastern Caribbean: Journal of Geophysical Research, v. 112, B04203, 19 p., https://doi.org/10.1029/2006JB004323.

Escuder Viruete, J., Pérez-Estaún, A., Weis, D., and Friedman, R., 2010, Geochemical characteristics of the Rio Verde Complex, Central Hispaniola-Implications for the paleotectonic reconstruction of the Lower Cretaceous Caribbean island-arc: Lithos, v. 114, p. 168-185.

Escuder Viruete, J., Suárez-Rodríguez, A., Gabites, J., and Pérez-Estaún, A., 2016, The Imbert Formation of northern Hispaniola-A tectono-sedimentary record of arc-continent collision and ophiolite emplacement in the northern Caribbean subduction-accretionary prism: Solid Earth, v. 7, p. 11-36, https://doi.org/10.5194/se-7-11-2016.

Escuder Viruete, J., Valverde-Vaquero, P., Rojas-Agramonte, Y., Gabites, J., and Pérez-Estaún, A., 2013, From intra-oceanic subduction to arc accretion and arc-continent collision: Insights from the structural evolution of the Río San Juan metamorphic complex, northern Hispaniola: Journal of Structural Geology, v. 46, p. 34-56, https://doi.org/10.1016/ j.jsg.2012.10.008.

Gerhard, L.C., Frost, S.H., and Curth, P.J., 1978, Stratigraphy and depositional setting, Kingshill Limestone, Miocene, St. Croix, U.S. Virgin Islands: American Association of Petroleum Geologists Bulletin, v. 62, no. 3, p. 403-418.

Grafe, F., Stanek, K.P., Baumann, A., Maresch, W.V., Hames, W.E., Grevel, C., and Millan, G., 2001, Rb-Sr and ${ }^{40} \mathrm{Ar}-{ }^{39} \mathrm{Ar}$ mineral ages of granitoid intrusives in the Mabujina unit, central Cuba-Thermal exhumation history of the Escambry Massif: Journal of Geology, v. 109, p. 615-631.

Hall, C.M., Kesler, S.E., Russell, N., Piñero, E., Roberto Sánchez, C., Mireya Pérez, R., Moreira, J., and Borges, M., 2004, Age and tectonic setting of the Camaguey volcanicintrusive arc, $\mathrm{Cuba}$ - Late Cretaceous extension and uplift in the western Greater Antilles: The Journal of Geology, v. 112, p. 521-542.

* Harland, W.B., Smith, A.G., and Wilcock, B., eds., 1964, Summary of the Phanerozoic time-scale, in The Phanerozoic time-scale: Geological Society London Quarterly Journal, suppl. v. 120-S, p. 260-262.
Hastie, A.R., 2007, The tectonomagmatic evolution of the Caribbean plate-Insights from igneous rocks on Jamaica: Cardiff, Wales, Cardiff University, Ph.D. dissertation, 204 p. Hastie, A.R., Kerr, A.C., McDonald, I., Mitchell, S.F., Pearce, J.A., Millar, I.L., Barfod, D., and Mark, D.F., 2010, Geochronology, geochemistry and petrogenesis of rhyodacite lavas in eastern Jamaica-A new adakite subgroup analogous to early Archaean continental crust?: Chemical Geology, v. 276, p. 344-359.

Hastie, A.R., Mitchell, S.F., Treloar, P., Kerr, A.C., Neill, I., and Barfod, D.N., 2013, Geochemical components in a Cretaceous island arc- The Th/La-(Ce/Ce*)Nd diagram and implications for subduction initiation in the inter-American region: Lithos, v. 162-163, p. 57-69.

* Hatten, C.W., 1957, Geology of the central Sierra de los Organos, Pinar Del Rio Province, Cuba: Austin, University of Texas, Report found at Library of the Institute for Geophysics, 48 p.

* Hatten, C.W., Schooler, O.E., Giedt, N.R., and Meyerhoff, A.A., 1958, Geology of central Cuba, eastern Las Villas and western Camagiiey Provinces: La Habana, Ministerio de Industrias, Internal Report.

Hatten, C.W., Somin, M., Millan, G., Renne, P., Kistler, R.W., and Mattinson, J.M., 1988, Tectonostratigraphic units of central Cuba: Transactions of the 11th Caribbean Geological Conference, Energy Division of the Ministry of Finance, Barbados, 1986, v. 35, p. 1-13.

Helsley, C.E., 1960, Geology of the British Virgin Islands: Princeton, N.J., Princeton University, Ph.D. dissertation, 219 p., approximate scale 1:60,000.

Hernaiz Huerta, P.P., Pérez-Valera, F., Abad, M., Monthel, J., and Diaz de Neira, A., 2012, Mélanges and olistostromes in the Puerto Plata area (northern Dominican Republic) as a record of subduction and collisional processes between the Caribbean and North-American plates: Tectonophysics, v. 568-569, p. 266-281, https://doi.org/10.1016/j.tecto.2011.10.020.

Iturralde-Vinent, M.A., García-Casco, A., Rojas-Agramonte, Y., Proenza, J.A., Murphy, J.B., and Stern, R.J., 2016, The geology of Cuba-A brief overview and synthesis: GSA Today, v. 26, no. 10 , p. 4-10.

James, K.H., 2005, Palaeocene to middle Eocene flyschwildflysch deposits of the Caribbean area-A chronological compilation of literature reports, implications for tectonic history and recommendations for further investigation: Transactions of the 16th Caribbean Geological Conference, Barbados, 2005, Caribbean Journal of Earth Science, v. 39, p. 29-46.

Jiang, M.M., 1993, Campanian calcareous nannofossils in the Sunderland Inlier, western Jamaica, in Wright, R.M., and Robinson, E., eds., Biostratigraphy of Jamaica: Geological Society of America Memoir 182, p. 19-28, https://doi.org/10.1130/MEM182-p19.

Kaye, C.A., 1959, Geology of Isla Mona, Puerto Rico, and notes on age of Mona Passage, with a section on The petrography of the phosphorites, by Z.S. Altschuler: U.S. Geological Survey Professional Paper 317-C, p. 141-178. 
Kesler, S.E., 1971, Petrology of the Terre-Nueve igneous province, northern Haiti: Geological Society of America Memoir 130, p. 119-137.

Kesler, S.E., Campbell, I.H., and Allen, C., 2005b, Age of the Los Ranchos Formation, Dominican Republic_-Timing and tectonic setting of PIA volcanism in the Caribbean region: Geological Society of America Bulletin, v. 117, nos. 7/8, p. 987-995, https://doi.org/10.1130/B25594.1 [data from Data Repository item 2005104].

Kesler, S.E., Campbell, I.H., Smith, C.N., Hall, C.H., and Allen, C.M., 2005a, Age of the Pueblo Viejo gold-silver deposit and its significance to models for high sulfidation epithermal mineralization: Economic Geology, v. 100, p. 253-272.

Kesler, S.E., and Fleck, R.J., 1967, Age and possible origin of a granitic intrusion in the Greater Antilles island arc [abs.]: Geological Society of America Special Paper 115, p. 482.

Kesler, S.E., Hall, C.M., Russell, N., Piñero, E., Roberto Sanchez, C., Mireya Pérez, R., and Moreira, J., 2004, Age of the Camagüey gold-silver district, Cuba-Tectonic evolution and preservation of epithermal mineralization in volcanic arcs: Economic Geology, v. 99, p. 869-886.

Kesler, S.E., Russell, N., Seaward, M., Rivera, J., McCurdy, K., Cumming, G.L., and Sutter, J.F., 1981, Geology and geochemistry of sulfide mineralization underlying the Pueblo Viejo gold-silver oxide deposit, Dominican Republic: Economic Geology, v. 76, p. 1096-1117.

Kesler, S.E., and Sutter, J.F., 1979, Compositional evolution of intrusive rocks in the eastern Greater Antilles island arc: Geology, v. 7, p. 197-200.

Kesler, S.E., Sutter, J.F., Barton, J.M., and Speck, R.C., 1991, Age of intrusive rocks in northern Hispaniola, in Mann, P., Draper, G., and Lewis, J.F., eds., Geologic and tectonic development of the North America-Caribbean plate boundary in Hispaniola: Geological Society of America Special Paper 262, p. 165-172.

Kesler, S.E., Sutter, J.F., Jones, L.M., and Walker, R.L., 1977, Early Cretaceous basement rocks in Hispaniola: Geology, v. 5, p. 245-247.

* Khudoley, K.M., 1967a, Principal features of Cuban geology: American Association of Petroleum Geologists Bulletin, v. 51, no. 7, p. 668-677.

* Khudoley, K.M., 1967b, Reply: American Association of Petroleum Geologists Bulletin, v. 51, no. 7, p. 789-791.

Kirk, J.D., Ruiz, J., Kesler, S.E., Simon, A., and Muntean, J.L., 2014, Re-Os age of the Pueblo Viejo epithermal deposit, Dominican Republic: Economic Geology, v. 109, p. 503-512.

Krebs, M., Maresch, W.V., Schertl, G.-P., Münker, C., Baumann, A., Draper, G., Idleman, B., and Trapp, E., 2008, The dynamics of intra-oceanic subduction zones-A direct comparison between fossil petrological evidence (Rio San Juan Complex, Dominican Republican) and numerical simulation: Lithos, v. 103, p. 106-137.

Krushensky, R.D., and Curet, A.F., 1984, Geologic map of the Monte Guilarte quadrangle, Puerto Rico: U.S. Geological Survey Miscellaneous Investigations Series Map I-1556, scale 1:20,000.
Krushensky, R.D., and Schellekens, J.H.., 1999, Geologic map of Puerto Rico with correlation chart and map unit descriptions, in Bawiec, W.J., ed., Geology, geochemistry, geophysics, mineral occurrences and mineral resource assessment for the Commonwealth of Puerto Rico: U.S. Geological Survey Open-File Report 98-038, scale 1:100,000,

https://pubs.usgs.gov/of/1998/of98-038/.

Kuman, V.E., and Gavilan, R.R., 1965, Geologia de Isla de Pinos: La Habana, Ministerio de Industrias, Rev. Tecnologica, v. 3, no. 4, p. 20-38.

Kysar, G., Mortensen, J.K., and Lewis, J.F., 1998, U-Pb zircon age constraints for Paleogene igneous rocks of the Sierra Maestra, Southeastern Cuba-Implications for short-lived arc magmatism along the northern Caribbean margin [abs.]: Geological Society of America Abstracts with Programs, v. 30, p. A-185.

Laverov, N., and Cabrera, R., 1967, Algunas particularidades de la geología de los alrededores del yacimiento El Cobre relacionadas con su génesis: Revista de Geología, Academia de Ciencias de Cuba, v. 1, p. 104-121.

Laverov, N.P., Shanin, L.L., and Cabrera-Ortega, P., 1967, The absolute age of certain rocks in Cuba, in Pushcharovskiy, Y.M., ed., Geology and mineral resources of Cuba (in Russian; translated by Aeronautical Chart and Information Center, St. Louis, Missouri, U.S. Department of Commerce, National Bureau of Standards, Institute for Applied Technology): Moscow, U.S.S.R., U.S.S.R. Academy of Sciences and Cuba Academy of Sciences, $197 \mathrm{p}$.

Lázaro, C., Blanco-Quintero, I.F., Proenza-Fernández, J.A., Rojas-Agramonte, Y., Neubauer, F., Núñez-Cambra, K., and García-Casco, A., 2016, Petrogenesis and ${ }^{40} \mathrm{Ar} /{ }^{39} \mathrm{Ar}$ dating of proto-forearc crust in the early Cretaceous Caribbean Arc - The La Tinta mélange (eastern Cuba) and its easterly correlation in Dominican Republic: International Geology Review, v. 58, p. 1020-1040, https://doi.org/10.1080/00206814.2015.1118647.

Lázaro, C., García-Casco, A., Blanco-Quintero, I.F., Rojas-Agramonte, Y., Corsini, M., and Proenza-Fernández, J.A., 2015, Did the Turonian-Coniacian plume pulse trigger subduction initiation in the Northern Caribbean? Constraints from ${ }^{40} \mathrm{Ar} /{ }^{39} \mathrm{Ar}$ dating of the Moa-Baracoa metamorphic sole (eastern Cuba): International Geology Review, v. 57, nos. 5-8, p. 919-942, https://doi.org/10.1080/00206814.2014.924037.

Lázaro, C., Garcia-Casco, A., Rojas-Agramonte, Y., Kroner, A., Neubauer, F., and Iturralde-Vinent, M., 2009, Fifty-fivemillion-year history of oceanic subduction and exhumation in the northern edge of the Caribbean plate (Sierra del Convento melange, Cuba): Journal of Metamorphic Geology, v. 27, no. 1, p. 19-40, https://doi.org/10.1111/j.1525-1314.2008.00800.x.

Learned, R.E., Grove, G.R., and Boissen, R., 1973, A geochemical reconnaissance of the Island of Vieques, Puerto Rico: U.S. Geological Survey Open-File Report 73-155, 78 p., 2 plates.

Lewis, J.F., Harper, C.T., Kemp, A.W., and Stipp, J.J., 1973, Potassium-argon retention ages of some Cretaceous rocks from Jamaica: Geological Society of America Bulletin, v. 84, p. 335-440. 
Lidz, B.H., 1988, Upper Cretaceous (Campanian) and Cenozoic stratigraphic sequence, northeast Caribbean, St. Croix, U.S. Virgin Islands: Geological Society of America Bulletin, v. 100, no. 2, p. 282-298.

Mann, P., and Burke, K., 1990, Transverse intra-arc riftingPalaeogene Wagwater Belt, Jamaica: Marine and Petroleum Geology, v. 7, p. 410-427.

Marchesi, C., 2006, Petrogenesis of the ultramafic and mafic rocks from the Mayarí-Baracoa Ophiolitic Belt and the spatially-related volcanism (Eastern Cuba): Granada, Universidad de Granada, Ph.D. dissertation, 139 p., 5 appendixes.

Matley, C.A., 1926, The geology of the Cayman Islands (British West Indies), and their relation to the Bartlett Trough: Quarterly Journal of the Geological Society, v. 82, nos. 1-4, p. 352-387, https://doi.org/10.1144/GSL.JGS.1926.082.01-04.21.

Mattson, P.H., 1960, Geology of Mayaguez area, Puerto Rico: Geological Society of America Bulletin, v. 71, p. 319-362, 6 plates.

Mattson, P.H., 1964, Petrography and structure of serpentinite from Mayaguez, Puerto Rico, in Burke, C.A. ed., A study of serpentinite; the AMSOC core hole near Mayaguez, Puerto Rico: National Academy of Science-National Research Council Publication 1188.

Mattson, P.H., 1967, Cretaceous and lower Tertiary stratigraphy in west-central Puerto Rico, in Contributions to stratigraphy: U.S. Geological Survey Bulletin 1254-B, p. B1-B35.

Mattson, P.H., 1973, Middle Cretaceous nappe structures in Puerto Rican ophiolites and their relation to the tectonic history of the Greater Antilles: Geological Society of America Bulletin, v. 84, p. 21-38.

Mattson, P.H., and Pessagno, E.A., Jr., 1974, Tectonic significance of Late Jurassic-Early Cretaceous radiolarian chert from Puerto Rican ophiolite [abs.]: Geological Society of America Abstracts with Programs, v. 6, pt. 7, p. 859.

Mattson, P.H., and Pessagno, E.A., Jr., 1979, Jurassic and Early Cretaceous radiolarians in Puerto Rican ophiolite-Tectonic implications: Geology, v. 7, p. 440-444.

Maurrasse, F.J.-M.R., 1982a, Survey of the geology of HaitiGuide to the field excursions in Haiti: Miami Geological Society, 108 p., accessed October 25, 2017, at https://www.researchgate.net/profile/Florentin_Maurrasse/ publication/257308015_FJ-MR_Maurrasse_1982 Survey_of_the_Geology_of_Haiti_MGS/ links/02e7e524de9c594679000000/FJ-MR-Maurrasse1982-Survey-of-the-Geology-of-Haiti-MGS.pdf.

* Maurrasse, F.J-M.R, 1982b, Les Marges continentales d'Haiti, in Maurrasse, F., ed., Transactions du lst Colloque sur la Geologie d'Haiti, Port-au-Prince, 27-29 March, 1980, p. 200-206.

McFarlane, N., Lyew-Ayee, D., Brookes, S., and Geddes, A.J., 1984, Jamaica geology: Kingston, Jamaica, Ministry of Mining and Natural Resources, Mines and Geology Division, scale 1:250,000.

McIntyre, D.H., Aaron, J.M., and Tobisch, O.T., 1970, Cretaceous and lower Tertiary stratigraphy in northwestern Puerto Rico, in Contributions to stratigraphy, 1969: U.S. Geological Survey Bulletin 1294-D, p. D1-D16.
Meyerhoff, A.A., and Hatten, C.W., 1968, Diapiric structures in central Cuba: American Association of Petroleum Geologists Memoir 8, p. 315-357.

Meyerhoff, A.A., Khudoley, K.M., and Hatten, C.W., 1969, Geologic significance of radiometric dates from Cuba: American Association of Petroleum Geologists Bulletin, v. 53, no. 12, p. 2494-2500.

* Millán, G., 1996, Geología del complejo Mabujina, in Iturralde-Vinent, M.A., ed., Cuban ophiolites and volcanic arcs: Miami, International Geological Correlation Project, v. 364, p. 147-153.

* Millán, G., and Somin, M.L., 1985, Contribution to the geologic knowledge of the metamorphics of Escambray and Purial [in Spanish]: Reporte de Investigacion 2, Academia de Ciencias de Cuba, p. 52-74.

* Millán-Trujillo, G., 1996, Metavulcanitas del Purial, in Iturralde-Vinent, M., ed., Ofiolitas y arcos volcanicos de Cuba: International Union of Geological Sciences-United Nations Educational, Scientific, and Cultural Organization, International Geological Correlation Program, Project 364, Special Contribution 1, p. 211.

Mitchell, S.F., 2000, Facies analysis of a Cretaceous-Paleocene volcaniclastic braid-delta: Geological Society of Trinidad and Tobago/Society of Petroleum Engineers (GSTT 2000 SPE) Conference, Port-of-Spain, Trinidad, Conference Proceedings CD Rom, SS03, 1-9 (separately numbered).

Mitchell, S.F., 2013a, Stratigraphy of the White Limestone of Jamaica: Bulletin de la Sociètè Geologiquè de France, v. 184, nos. 1-2, p. 111-118, https://doi.org/10.2113/ gssgfbull.184.1-2.111.

Mitchell, S.F., 2013b, The lithostratigraphy of the Central Inlier, Jamaica: Caribbean Journal of Earth Science, v. 46, p. 31-42.

Mitchell, S.F., Abbott, R.N., Bhalai, S., Dwyer, S., Edwards, T.C.P., and 20 others, 2016, Revision of Jamaican lithostratigraphic nomenclature decided at a stratigraphic workshop of the Jamaican Stratigraphic Committee at the 60th Anniversary of the Geological Society of Jamaica: Caribbean Journal of Earth Science, v. 48, p. 37-45.

Mitchell, S.F., and Blissett, D., 2001, Lithostratigraphy of the Late Cretaceous to ?Paleocene succession in the western part of the Central Inlier of Jamaica: Caribbean Journal of Earth Science, v. 35, p. 19-31.

Mitchell, S.F., Ramsook, R., Coutou, R., and Fisher, J., 2011, Lithostratigraphy and age of the St. Ann's Great River Inlier, northern Jamaica: Caribbean Journal of Earth Science, v. 42, p. 1-16.

Nelson, A.E., 1966, Cretaceous and Tertiary rocks in the Corozal quadrangle, northern Puerto Rico, in Contributions to stratigraphy, 1966: U.S. Geological Survey Bulletin, 1244-C, p. C9-C10.

Nelson, A.E., 1967, Geologic map of the Utuado quadrangle, Puerto Rico: U.S. Geological Survey Miscellaneous Geologic Investigations Map I-480, scale 1:20,000.

Nelson, C.E., Stein, H., Dominguez, H., Carrasco, C., Barrie, T., Torró, L., and Proenza, J., 2015, Re-Os dating of molybdenite from the Pueblo Viejo Au-Ag-Cu and Douvray $\mathrm{Cu}-\mathrm{Au}$ Districts, Hispaniola: Economic Geology, v. 110, p. 1101-1110. 
Pardo, G., 2009, The geology of Cuba: American Association of Petroleum Geologists, AAPG Studies in Geology \#58, 73 p.

Pauca, M.J.M., 2014, Epithermal mineralization associated with diatreme breccia and rhyolitic dome, La Miel, Haiti: Tucson, University of Arizona, M.S. thesis, 100 p.

Pease, M.H., Jr., 1968, Cretaceous and lower Tertiary stratigraphy of the Naranjito and Aguas Buenas quadrangles and adjacent areas, Puerto Rico: U.S. Geological Survey Bulletin $1253,57 \mathrm{p}$.

Pushcharovsky, Y., and others, eds., 1988, Mapa geologico de la Republica de Cuba: Academy of Sciences of Cuba and U.S.S.R., 42 sheets, scale 1:250,000.

Rankin, D.W., 2002, Geology of St. John, U.S. Virgin Islands: U.S. Geological Survey Professional Paper 1631, 42 p., scale 1:24,000, https://pubs.usgs.gov/pp/p1631/.

Renne, P.R., Mattinson, J.M., Hatten, C.W., Somin, M., Onstott, T.C., Millan, G., and Linares, E., $1989,{ }^{40} \mathrm{Ar} /{ }^{39} \mathrm{Ar}$ and U-Pb evidence for Late Proterozoic (Grenville age) continental crust in north-central Cuba and regional tectonic implications: Precambrian Research, v. 42, p. 325-341.

Robinson, E., and Mitchell, S.F., 1999, Upper Cretaceous to Oligocene stratigraphy in Jamaica, in Mitchell, S.F., ed., Contributions to geology: University of West Indies, Mona, no. 4 , p. $1-47$.

Rodríguez-Crombet, R., Rodríguez, M., and Yassel, A., 1997, Características del magmatismo granitoideo de Cuba Oriental (región Sierra Maestra), in Furrazola-Bermúdez, G., and Núñez Cambra, K., eds., Estudios sobre Geología de Cuba: La Habana, Centro Nacional de Información Geológica, p. 446-462.

Rogers, C.L., 1977, Geologic map of the Punta Guayanes quadrangle, Puerto Rico: U.S. Geological Survey Miscellaneous Investigations Map I-998, scale 1:20,000.

Rojas-Agramonte, Y., Kroner, A., Garcia-Casco, A., Kemp, T., Hegner, E., Perez, M., Barth, M., Liu, D., and Fonseca-Montero, A., 2010, Zircon ages, Sr-Nd-Hf isotopic compositions, and geochemistry of granitoids associated with the Northern Ophiolite Mélange of central Cuba-Tectonic implication for Late Cretaceous magmatism in the northwestern Caribbean: American Journal of Science, v. 310, p. 1453-1479, https://doi.org/10.2475/10.2010.09.

Rojas-Agramonte, Y., Kroner, A., Garcia-Casco, A., Somin, M., Iturralde-Vinent, M., Mattinson, J.M., Millán Trujillo, G., Sukar, K., Perez Rodriguez, M., Carrasquilla, S., Wingate, M.T.D., and Liu, D.Y., 2011, Timing and evolution of Cretaceous island arc magmatism in central Cuba-Implications for the history of arc systems in the northwestern Caribbean: Journal of Geology, v. 119, p. 619-640.

Rojas-Agramonte, Y., Neubauer, F., Bojar, A.V., Hejl, E., Handler, R., and García-Delgado, D.E., 2006, Geology, age and tectonic evolution of the Sierra Maestra Mountains, southeastern Cuba: Geologica Acta, v. 4, nos. 1-2, p. 123-150.

Rojas-Agramonte, Y., Neubauer, F., Kroner, A., Wan, Y.S., Liu, D.Y., Garcia-Delgado, D.E., and Handler, R., 2004, Geochemistry and early Palaeogene SHRIMP zircon ages for island arc granitoids of the Sierra Maestra, southeastern Cuba: Chemical Geology, v. 213, p. 307-324.
Roobol, M.J., 1972, The volcanic geology of Jamaica: Transactions, 6th, Caribbean Geological Conference, Margarita, Venezuela, Cromotip Publishing, Caracas, Venezuela, p. 100-107.

Schellekens, J.H., Montgomery, H., Joyce, J., and Smith, A.L., 1990, Late Jurassic to Late Cretaceous development of the island arc crust in southwestern Puerto Rico, in Larue, D.K., and Draper, G., eds., Transactions of the 12th Caribbean geological conference, St. Croix, U.S. Virgin Islands: Miami Geological Society, Transactions of the 12th Caribbean Geological Conference, St. Croix, U.S. Virgin Islands, August 7-11, 1989, no. 12, p. 268-281.

Schneider, J., Bosch, D., Monie, P., Guillot, S., García-Casco, A., Lardeaux, J.M., Torres-Roldán, R.L., and Millán-Trujillo, G., 2004, Origin and evolution of the Escambray Massif (Central Cuba) - An example of hp/lt rocks exhumed during intraoceanic subduction: Journal of Metamorphic Geology, v. 22, p. 227-247.

Schrecengost, K.L., 2010, Geochemistry and U/Pb zircon geochronology of the Virgin Islands batholith, British Virgin Islands: Chapel Hill, University of North Carolina, Ph.D. dissertation, $73 \mathrm{p}$.

Seiders, V.M., 1971, Cretaceous and lower Tertiary stratigraphy of the Gurabo and El Yunque quadrangles, Puerto Rico, in Contributions to stratigraphy, 1969: U.S. Geological Survey Bulletin 1294-F, p. F1-F58.

Sinton, C.W., Duncan, R.A., Storey, M., Lewis, J.F., and Estrada, J., 1998, An oceanic flood basalt province within the Caribbean plate: Earth and Planetary Science Letters, v. 155, p. 221-235.

Somin, M., and Millán, G., 1981, Geology of the metamorphic complexes of Cuba [in Russian]: Moscow, U.S.S.R., 218 p.

Somin, M.L., Arkelyants, M.M., and Kolenikov, E.M., 1992, Vozrast i tektonicheskoye znacheniye vysokobaricheskikh metamorficheskikh porod Kuby [in Russian: Age and tectonic significance of high-pressure metamorphic rocks of Cuba]: Izvestiya RAN, seiya geologicheskaya, no. 3, p. 91-104. [English translation published in International Geology Review, v. 34, no. 2, p. 105-118.]

Somin, M.L., and Millán, G., 1977, Sobre la edad de las rocas metamorficas Cubanas: Informe cientffico-tecnico no. 2, Instituto de Geologfa y Paleontologfa, Academia de Ciencias de Cuba, 11 p.

Speed, R.C., Gerhard, L.C., and McKee, E.H., 1979, Ages of deposition, deformation, and intrusion of Cretaceous rocks, eastern St. Croix, Virgin Islands: Geological Society of America Bulletin, part 1, v. 90, p. 629-632.

Steiger, R.H., and Jager, E., 1977, Subcommission on geochronology-Convention on the use of decay constants in geoand cosmochronology: Earth and Planetary Science Letters, v. 36, p. 359-362.

Sukar, K., and Pérez, M., 1997, Granitoides del arco vol cánico de la región central de Cuba antigua provincial de Las Villas, in Furrazola Bermúdez, G.F., and Núňez Cambra, K.E., eds., Estudios sobre geología de Cuba: Havana, Instituto de Geología y Paleontología, Centro Nacional de Información Geológica, p. 371-386. 
Toloczyki, M., Ramirez, I., Eberle, W., Mollat, H., Cepek, P., Weiss, W., and Echevarria, F., 1991, Mapa geologico de la Republica Dominicana 1:250,000 [in Spanish] (Geologic map of the Dominican Republic): Ministry of Industry and Commerce, Department of Mining, Geographic Institute of the Univerisity of Santo Domingo, scale 1:250,000.

Torró, L., Camprubí, A., Proenza, J.A., León, P., Stein, H.J., Lewis, J.F., Nelson, C.E., Chavez, C., and Melgarejo, J.C., 2017, Re-Os and U-Pb geochronology of the Doña Amanda and Cerro Kiosko deposits, Bayaguana District, Dominican Republic_-Looking down for the porphyry $\mathrm{Cu}-\mathrm{Mo}$ roots of the Pueblo Viejo-type mineralization in the island-arc tholeiitic series of the Caribbean: Economic Geology, v. 112, p. 829-853, https://doi.org/10.2113/econgeo.112.4.829.

Torró, L., Proenza, J.A., Rojas-Agramonte, Y., Garcia-Casco, A., Yang, J.-H., and Yang, Y.-H., 2018, Recycling in the subduction factory-Archaean to Permian zircons in the oceanic Cretaceous Caribbean island-arc (Hispaniola): Gondwana Research, v. 54, p. 23-37.

Vila, J.-M., Andreieff, P., Bellon, H., and Mascle, A., 1986, Tectonique de collage le long d'un accident décrochant, ante oligocéne, est-ouest, dans les Iles Vierges septentrionales (Antilles): Comptes Rendus Académie des Sciences, Paris, Tome 302, série II, no. 4, p. 141-144.
Vila, J.-M., Butterlin, J., Calmus, T., Mercier de Lépinay, B., and van den Berghe, B., 1985, Carte géologique d'Haïti au 1/1,000,000 avec notice explicative détaillée [in French: Geologic map of Haiti at 1:1,000,000 with detailed explicative notes], in Girault, C., ed., Atlas d'Haiti: Talence, France, Centre d'etudies de geographe tropicale (CNRS) et Universite de Bordeaux, France, scale 1:1,000,000.

Volckmann, R.P., 1984, Upper Cretaceous stratigraphy of southwest Puerto Rico-A revision, in Stratigraphic notes, 1983: U.S. Geological Survey Bulletin 1537-A, p. A73-A83.

Wadge, G., 1982, A Miocene submarine volcano at Low Layton, Jamaica: Geological Magazine, v. 119, no. 2, p. 193-199, https://doi.org/10.1017/S0016756800025875.

Wadge, G., Draper, G., and Lewis, J.F., 1983, Ophiolites of the northern Caribbean, a reappraisal of their roles in the evolution of the Caribbean plate boundary, in Gass, L.G., Lippard, S.J., and Shelton, J.W., eds., Ophiolites and oceanic lithosphere: Geological Society of London Special Publication, v. 13 , p. $367-380$.

Wadge, G., and Wooden, J.L., 1982, Late Cenozoic alkaline volcanism in the northwestern Caribbean-Tectonic setting and $\mathrm{Sr}$ isotope characteristics: Earth and Planetary Science Letters, v. 57, p. 35-46.

Whetten, J.T., 1966, Geology of St. Croix, U.S. Virgin Islands: Geological Society of America Memoir 98, p. 177-239, 1 plate, scale 1:31,680. 